\title{
Installation of a Devonian Shale Reservoir Testing Facility and Acquisition of \\ Reservoir Property Measurements
}

Final Report

C.D. Locke

S.P. Salamy

Work Performed Under Contract No.: DE-AC21-84MC21216

\author{
For \\ US. Department of Energy \\ Office of Fossil Energy \\ Morgantown Energy Technology Center \\ P.O. Box 880 \\ Morgantown, West Virginia 26507-0880 \\ By \\ The BDM Corporation \\ 7915 Jones Branch Drive \\ Mclean, Virginia 22102
}

September 1991 


$$
\text { LIST OF FIGURES }
$$

LIST OF TABLES

vi

1.0 EXECUTIVE SUMMARY $1-1$

2.0 INTRODUCTION 2-1

3.0 RESERVOIR PROPERTIES WELLS 3-1

3.1 Site Selection 3-1

3.2 Field Operations 3-2

3.2.1 Drilling and Coring $3-3$

3.2 Logging $3-4$

3.2.3 Well Testing 3-5

3.3 Procedures and Analyses 3-6

3.3.1 Core Analysis 3-6

3.3.2 Log Analysis 3-13

3.3.3 Well Test Analyses 3-14

4.0 OFFSET WELL TEST FACILITY 4-1

4.1 The Test Site 4-1

4.2 Field Operations 4-3

4.2.1 Drilling and Completion Activities 4-6

4.2.2 Offset Well Testing 4-8

4.2.3 Foam Frac Stimulation of Offset Well No. 3

4.2.4 Big Lime Recompletions 4-25

5.0 RESULTS AND CONCLUSIONS 5-1

5.1 Core Analyses 5-1

5.2 Well Test Analysis of Reservoir Properties Wells 5-1

5.3 Offset Well Test Facility 5-10

5.3.1 Test Site Geology 5-10

5.3.2 Interwe11 Transient Tests at Offset Well Test 5-21

5.3.3 Induced Fracturing and Fracture Diagnostics $5-26$

5.3.4 Big Lime and Devonian Shale Interaction 5-29

5.4 Conclusions

6.0 REFERENCES 


\section{LIST OF FIGURES}

FIGURE NO.

PAGE

2-1 Map Showing the Designated Target Areas

3-1 Typical Well Set-up for Production Testing 3-7

3-2 Typical Surface Facilities for Production Testing 3-8

3-3 Example Graph Comparing Wellhead and Bottomhole 3-16

3-4 Example Graph Showing Bottomhole Pressure versus 3-17

3-5 Example of Prefrac Drawdown Plot Illustrating the 3-19

3-6 Example of Semi-log Plot of Prefrac Drawdown Data 3-20

3-7 Example of Prefrac Build-up Curve (Horner Time Semi- 3-22 Log Plot)

4-1 Original Well Pattern Chosen for the Offset Well Test 4-2 Facility, Whitley County, Kentucky

4-2 Revised Well Pattern Chosen for the Offset Well Test 4-4 Facility, Whitley County, Kentucky

4-3 Bottomhole Locations of Wells at the Offset Well Test 4-5 Facility, Whitley County, Kentucky

4-4 Initial Well Completion Configurations for Wells at 4-7 the offset Well Test Facilities

4-5 Pressures at Offset Well Test Facility During Nitrogen 4-9 Injection into Offset Well No. 1

4-6 Pressure Responses at Offset Well No. 3 and Raymond Chandler No. 1 Wells During Nitrogen Injection Into Offset Well No. 1

4-7 Pressure Responses at the Offset Wells During Pulse Testing; Pulses Applied to the Chandler No. 1 Well

4-8 Pressure Response at Offset Well No. 2 During Pulse Testing; Pulses Applied to Offset No. 1 
FIGURE NO.

PAGE

4-9

Interference Test Pressure Response During Flow and

Shut-in Periods for Offset Well No. 1

4-10 Typical Tiltmeter Installation

4-11 Location of Tiltmeter Sites

4-12. Fracture Zones from SLAR and Landsat Maps at the Offset Well Test Facility Site, Whitley County, KY

4-13 Schematic of Offset Pressure Monitoring Wells During Stimulation of Offset Well No. 3

4-14

Schematic of Pressure Monitoring System for Offset Well No. 3 During Its Foam-Frac Treatment

4-15 Bottomhole and Surface Injection Pressures During Stimulation of Offset Well No. 3

4-16 Pressure Responses at Monitoring Wells During Stimulation of Offset Well No. 3, First Two Hours

4-17 Pressure Responses at Monitoring Wells During and Following Stimulation of Offset Wel1 No. 3, First 17 Hours

4-18 Offset We11 No. 2 Wellbore Dual-Completion
Configuration for Testing Big Lime at the Offset We11 Test Facility

Offset Well No. 1 Wellbore Configuration for Testing Big Lime at the Offset Well Test Facility

Pressure History and History Match for the Chandler No. 2 Well No. 1, and Offset We11 No. 2 During Pulses Applied to the Chandler No. 2

5-1 Stratigraphic Column and Nomenclature Used Mountain Area of the R. Chandler No. 1 
LIST OF FIGURES (continued)

FIGURE NO.

PAGE

5-4 Coring-Induced Petal Centerline Strike Directions 5-16

5-5 Devonian Shale Joints in Outciop 5-17

5-6 Regional Natural Fracture Trends in Devonian Shale Cores 5-18

5-7 Regional Isopach of the Devonian Shale 5-19

5-8 Tilt Vectors Resulting from the Stimulation of OWTF \#3 5-27

5-9 Pressures Monitored in the Chattanooga Shale During 5-31 Drawdown Test on Offset Well No. 3 
TABLE NO.

PAGE

5-1 Basic Core Analysis Summary

5-3 Summary of Core Gas Desorption 5-4

5-4 Core Analysis Averages Summaries 5-5

5-5 Summary of Rock Mechanics Data Indicating Preferred 5-6 Fracturing Orientation

5-6 Results of Stress Tests and Well Test Analyses 5-7

5-7 Natural Gas Sample Analyses 5-8

5-8 Brine Sample Analyses 5-9

5-9 Results of Individual Well Tests 5-22

5-10 Pulse Test Results 5-24

5-11 Type Curve Matching Parameters for Interference Test \#1 5-24

5-12 Results of Interference Test \#1 5-24

5-13 Type Curve Matching Parameters for Interference Test \#2 5-25

5-14 Results of Interference Test \#2 5-25

5-15 Comparison of Results of Interference Tests \#1 and \#2 5-25 


\subsection{EXECUTIVE SUMMARY}

In October 1984, DOE/Morgantown Energy Technology Center (DOE/METC) awarded a contract to The BDM Corporation for the Installation of a Devonian Shale Reservoir Testing Facility and Acquisition of Reservoir Property Measurements from wells in the Michigan, Illinois, and Appalachian Basins. Geologic and engineering data collected through this project, when coupled with data collected by the past EGSP, will provide a better understanding of the mechanisms and conditions controlling shale gas production.

This report summarizes the results obtained from the various testing procedures used at each wellsite and the activities conducted at the Reservoir Testing Facility. Detailed reports on each of the Reservoir Properties wells have been provided previously to DOE/METC in Morgantown, West Virginia.

DOE/METC designated 10 target areas from which data for this project was to be collected (Figure 2-1). Two target areas in the Michigan Basin were to test the Antrim shale while an Illinois target was to evaluate the New Albany shale. In the Appalachian Basin, seven target areas were identified for testing. Four targets (D, E, $F$, and $J$ ) were to test the Rhinestreet shale and the remaining three (G, H, I) were to test the deeper Marcellus shale. Cooperative agreements were struck with companies in the various target areas to work with them on a production well they were drilling to, nearly to, or through the target shale horizon for the particular target area.

Reservoir properties "wells-of-opportunity" were cored using air or air-mist as the drilling fluid, except where water-based fluids were otherwise required. Coring was accomplished typically using a 7-5/8-inch or 7-27/32-inch by 3-1/2-inch Stratapax core bit with a 60-foot oriented core barrel. Core analyses included both standard and specialized procedures plus rock mechanics testing. Each well was logged using Schlumberger Well Services, Inc., to assure compatibility and comparability between logs of wells logged under this contract as well as with wells logged previously under other contracts in the Eastern Gas Shales Program. 
Well tests included conventional drawdown/build-up tests plus tests to determine minimum in-situ stress. Core analysis and well test analysis results are summarized in Tables 5-1 through 5-8.

The contract-specified Reservoir Test Facility, or Offset Well Test Facility (OWTF) as it later became known, was located in Whitley County, southeastern Kentucky. The site was selected because it was in an area that had not been highly-researched during the earlier EGSP investigations and it was also an area of interest to $0 i 1$ and gas operators. Significant gas "shows" and initial "open flows" measured in the area indicated that the Chattanooga shale had potential there, but little was known about the reservoir. A cooperative well drilled with Alpha Gas Development had a pre-stimulation open-flow of $20 \mathrm{mscf} /$ day and a post-stimulation open-flow of approximately $280 \mathrm{mscf} /$ day. Three wells were drilled in close proximity to this original producing well to establish the offset Well Test Facility. Tests conducted at the site included conventional drawdown and build-up tests, interference tests, pulse tests, a stimulation test, and tiltmeter studies of the stimulation test. Data from these tests are combined with rock mechanics tests, core analyses, and geological studies to provide an improved understanding of the parameters influencing gas production from the Chattanooga shale in the vicinity of the OWTF site. Data were also collected and analyzed to determine possible interference by a well on the site producing from the Big Lime formation, approximately 500 feet above the Chattanooga.

The Chattanooga shale at the Whitley County, Kentucky, Offset Well Test Facility site was determined to be highly-fractured and faulted. Even so, permeability was very low (less than 0.2 md average) and stimulation by hydraulic fracturing is necessary for commercial production. Porosity is low for the Chattanooga, between one and two percent, and gas content by adsorption is also relatively low because of the low reservoir pressure (approximately $300 \mathrm{psi}$ ). Gas can be produced commercially, however, from the chattanooga because of the fact that there are other gas productive zones in close proximity to the Chattanooga, particularly the "Big Lime" and the Waverly shale. 
The probable orientation of a hydraulic fracture induced in

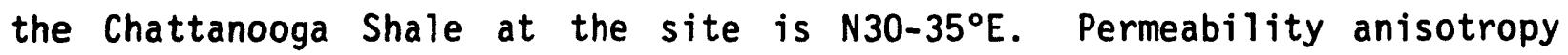
from the last interference test conducted at the site was calculated to be approximately 20:1, with the direction of maximum permeability being $N 30^{\circ} \mathrm{W}$.

A wide range of reservoir parameters were found for the various Devonian shale formations tested. Core (rock matrix) permeabilities generally fell in the same range as the permeabilities determined in prior work. Porosities, likewise, were similar. Both Rhinestreet shale and Marcellus shale formations indicated somewhat higher porosities than the Huron shales, the most common producing horizon, ranging from 2-5 percent for the Rhinestreet and up to 10 percent for the Marcellus, compared to 1-4 percent for the Huron. Neither the Rhinestreet nor the Marcellus were significantly more permeable as a result of the higher porosity values because little of the porosity was interconnected. As a result, the same criteria exist for the successful development of a natural gas resource within these horizons as is the case for the Huron; i.e., natural fracture development is essential for commercial gas production. Stimulation of a well in an area of undeveloped or poorly developed natural fractures will not generate sufficient reserves for commercial production.

The results of the investigations conducted under this program were similar to those of previous studies. Natural fractures within the shales contain nearly all of the permeability of the reservoir but contain only a small part of the natural gas resource. The successful exploitation of these resources depends on the development of technologies to detect or predict the occurrenie of naturally-fractured zones. It is also necessary to satisfactorily connect the wellbore with these fractured zones through improved hydraulic fracturing or other techniques such as directional drilling. 


\subsection{INTRODUCTION}

In 1976, the U.S. Department of Energy (DOE) initiated a program designed to expand the knowledge base and linderstanding of unconventional energy resources. The Eastern Gas Shale Project (EGSP) was to make an assessment of the commercial production potential of natural gas from Middle and Upper Devonian shales in the eastern United States. The specific objectives of the EGSP were to:

0 Evaluate recoverable reserves of gas in the shales;

o. Enhance recovery technology for production from shale reservoirs;

- Stimulate interest among commercial producers regarding production of gas from Devonian shales.

In October 1986, DOE/Morgantown Energy Technology Center (DOE/METC) awarded a contract to The BDM Corporation for the Installation of a Devonian Shale Reservoir Testing Facility and Acquisition of Reservoir Property Measurements from wells in the Michigan, Illinois, and Appalachian Basins. Geologic and engineering data collected through this project, when coupled with data collected by the past EGSP, will provide a better understanding of the mechanisms and conditions controliing shale gas production.

The primary objective of this report is to summarize the results obtained from the various testing procedures used at each wellsite and to provide a more comprehensive report of activities conducted at the Reservoir Testing Facility. Detailed reports on each of the Reservoir Properties wells have been provided previously to DOE/METC in Morgantown, West Virginia.

DOE/METC designated 10 target areas from which data for this project was to be collected (Figure 2-1). Two target areas in the Michigan Basin were to test the Antrim Shale while an Illinois target was to evaluate the New Albany Shale. In the Appalachian Basin, seven trget areas were identified for testing. Four targets (D, E, F, and $J$ ) were to test the Rhinestreet Shale and the remaining three (G, $H$, and I) were to test the deeper Marcellus Shale. The target areas selected were based on 


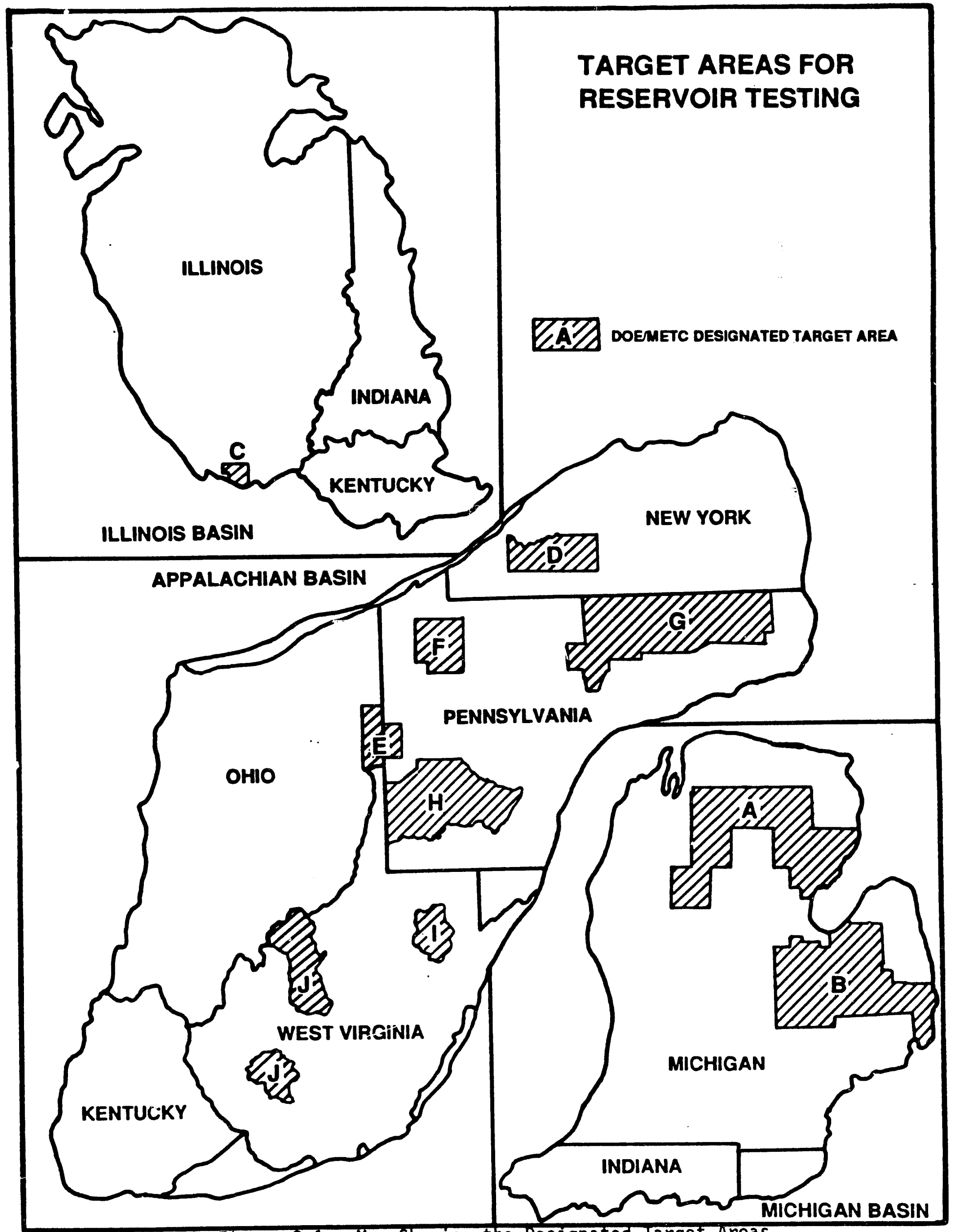

Figure 2-1. Map Showing the Designated Target Areas 
work completed in the EGSP. Criteria used to select these sites included shale thickness, organic content, mechanical stress distribution, and thermal maturity.

Cooperative agreements were struck with companies in the various target areas to work with them on a production well they were drilling to, nearly to, or through the target shale horizon for the particular target area. The cooperative agreements utilized for obtaining cores and test data varied with the cooperating company, but typically consisted of clauses delineating the items of responsibility (and/or liability) for each party, a time schedule for making the well available for testing, and limited confidentiality of information obtained from the well. Most operators asked for BDM to pay all costs above those that would normally be incurred by the operator in the course of drilling and completing the well, would provide about four to six weeks for well testing, and asked that publication of company confidential data relevant to the test well be delayed by six months. Table 2-1 shows the cooperating companies for each of the target areas.

The contract-specified Reservoir Test Facility, or Offset Well Test Facility (OWTF) as it later became known, was located in Target Area $B$ in Whitley County, southeastern Kentucky. The site was selected because it was in an area that had not been highly-researched during the earlieiEGSP investigations and it was also an area of interest to oil and gas operators. Significant gas "shows" and initial "open flows" measured in the area indicated that the Chattanooga Shale had potential there, but little was known about the reservoir. A cooperative well drilled with Alpha Gas Development had a pre-stimulation open-flow of $20 \mathrm{mscf} /$ day and a post-stimulation open-flow of approximately $280 \mathrm{mscf} /$ day. of all the wells drilled under the Reservoir Properties phase of the project, this well and reservoir came closest to meeting the desired characteristics for the OWTF. Therefore, a cooperative agreement subcontract was negotiated with Alpha Gas Development to drill three offset wells on close spacing relative to the initial well for test purposes. Tests ultimately to be conducted at the site included individual well drawdown 
and buil'-up tests, interference tests, pulse tests, a stimulation test, and tiltrieter studies of the stimulation test. Data from these tests are combined with rock mechanics tests, core analyses, and geological studies to provide an improved understanding of the param ters influencing gas production from the Chattanooga Shale in the vicinity of the OWTF site. 
TABLE 2-1. COOPERATING COMPANIES

TARGET AREA / LOCATION

A Northern Michigan

B Southeastern Kentucky (originally East-central Michigan

C Southern Illinois

D Southwestern New York

E Northeastern Ohio and Western Pennsylvania

F Northwestern Pennsylvania

G Northern Pennsylvania

H Southwestern Pennsylvania

I Northcentral West Virginia

$\mathrm{J}$ Western and Southwestern West Virginia

\section{COOPERATOR}

Terra Energy

Alpha Gas Development

Ashland

Seneca Nation of Indians

Carless Resources

Wainoco 0 il and Gas

Union Drilling

Cancelled. Previous EGSP core data from area, coupled with little or no drilling activity in the area.

Union Drilling

Pennzoil 


\subsection{RESERVOIR PROPERTIES WELLS}

\subsection{Site Selection}

The site selection process for reservoir properties wells was driven primarily by the requirements for the Reservoir Testing Facility because each site selected for properties measurements was assumed to be a potential candidate site for installation of the Testing Facility. Therefore, the reservoir properties wellsites were chosen so that as many of the contract-specified criteria for the Testing Facility would be met as was reasonably possible. Those criteria were specified in the contract as follows:

The offset well reservoir site shall contain an existing producing shale well with the following characteristics:

- A control well drilled in a proven shale-producing trend or as a step-out to older production.

o No other currently producing shale wells within approximately 3000 to 5000 feet of the subject well.

- A productive shale interval between 1000 to 4000 feet in depth to minimize offset well drilling costs and testing problems.

- A geophysical $\log$ suite across the shale intervals of interest.

o The well was completed in the shale as an open-hole shot well or is producing naturally.

- Available bottomhole formation pressure data from early in the producing life. Current reservoir pressure should be at least 400 psig.

- Sustained pressure/production history of at least 2 to 5 years. Production rates and downtime information must be accurately known. Current production rate should be at least 25 mcfpd.

0 The well should be in an area free from the influence of any known detrimental geologic feature or anomaly. 
It was found to be practically impossible to satisfy all of the criteria specified in the contract for the Testing Facility site; therefore, priorities were established regarding the criteria to be satisfied. The criteria that were to be satisfied first were:

(1) Sustained, measurable production -- at least $5 \mathrm{mscf} /$ day $\mathrm{rather}$ than $25 \mathrm{mscf} /$ day, with higher production rates to be preferred over lower rates.

(2) A productive shale interval between 1000 and 4000 feet in cepth to minimize offset well drilling costs and testing problems.

(3) Current reservoir pressure adequate for conducting the vrious tests required at the OWTF; ideally but not necessarily, 400 psig or greater.

(4) No other currently producing shale wells within 2000 feet, ideally 3000 feet or more.

The remaining contract-specified criteria would be satis ied next. For each site considered, a detailed analysis of the site geology and available engineering data was made. Upon determining a site or sites to be reasonably representative of the target urea and mee: ng some, if not all, of the site selection criteria, the site or sites were presented to the Department of Energy's technical representative for the contract stating the advantages and disadvantages of the site aiong with the prospects for obtaining a better site within the given tar:at area. This procedure was repeated for each designated target area. Upon approval of a specific site, a cooperative agreement was negotiated with the operator, approved by the DOE, and implemented.

\subsection{Field Operations}

Field operations consisted of drilling and coring, logging, and well testing. Drilling and coring operations varied somewhat with the circumstances of the well. The well on Wainoco's property in Crawford County, Pennsylvania, for example, was a complete "farmout" with BOM 
acting as the operator. The well on Ashland's property in Illinois involved deepening the well below Ashland's target horizon, so BDM took control of the well to deepen it and to core the target New Albany Shale. The cooperative well with Carless Resources in Mahoning County, Ohio, was a case where the operator's target (Clinton Sand) was deeper than the designated shale target (Rhinestreet). These three wells represent the three basic types of cooperative operations that were conducted during the execution of this R\&D program.

\subsubsection{Drilling and Coring}

Most wells drilled to or through the Devonian shales in the eastern United States are drilled using air as the drilling fluid. For the most part, air was the drilling fluid of choice for the cooperative wells under this program. Exceptions to this general rule were taken where significant volumes of liquids were known or expected to be produced during drilling operations or where wellbore stability or safety precautions dictated the use of water-based drilling muds.

Coring of wells utilized air or air-mist as the drilling fluid, except where water-based fluids were required as noted above. Coring was accomplished typically using a 7-5/8 inch or 7-27/32 inch by 3-1/2 inch Stratapax core bit with a 60-foot oriented core barrel. The coring procedure consisted of drilling (coring) for two feet, shutting down for four minutes to allow the automatic camera to photograph the orientation compass, and then repeating the process for another two-foot interval. With the 60-foot core barrel, only 58 feet of core would be taken to prevent "jamming" of the core barrel.

The core recovery procedure utilized a plastic sleeve to protect the core during coring and removal of the core from the core barrel. The core was laid out on the pipe rack as soon as it was removed from the core barrel. It would then be washed and/or wiped dry, measured and marked, and given a preliminary examination and description. Obvious fractures and other features of interest would be noted at that time as would any indication of the presence of natural gas. As soon as the 
preliminary examinations and description of the core was completed, eight to ten samples were collected and sealed in metal canisters for desorption testing. The remaining core was then removed from the site and taken to BDM's Morgantown, WV, office for detailed examination, description, and fractographic analysis. During this examination, approximately six samples would be selected and sent to Petrophysical Services, Inc., the subcontractor for petrophysical testing and analysis. After the detailed examination and fractographic analysis, the remaining core material was boxed and shipped to Michigan Technological University for mechanical rock properties testing.

\subsubsection{Logging}

Each well was logged using Schlumberger Well Services, Inc., to assure compatibility and comparability between logs of wells logged under this contract as well as with wells logged previously under other contracts in the Eastern Gas Shales Program. Normally, the typical "open-hole" logging suite would consist of the following logs:

- Temperature Log

- Dual Induction Log

- Audio Log

- Lithodensity/Sidewall Neutron

- Caliper

- Natural Gamma Ray Spectrography

Where conditions required drilling and/or coring with water-based $f^{\prime}$ uids, a "wet-hole" logging suite was utilized. An example of this $t$ o of logging suite is that which was run on the Stevens \#1-12 well in Dtsego County, Michigan:

- Litho Density

- Dual Laterolog/Micro Laterolog/GR

- Long Spacing Sonic/Wave Forms/GR

- Natural Gamma Ray Spectroscopy

- Conpensated Neutron 


\section{- Mechanical Properties Log}

- High Resolution Dipmeter Log

In addition to the standard service company logs, the wells were logged with a downhole video camera to visually detect fractures intersecting the wellbore. Sometimes this was done before and after stress testing the well to see if fractures opened by the stress test could be identified and oriented. This was not very successful in that the results were isually inconclusive; i.e., either no new fracture could be observed or apparently new fractures had wellbore signatures that were insufficient for orientation.

\subsubsection{Well Testing}

Two basic types of well tests were conducted to obtain reservoir property information. Where the formation of interest was not the operator's target for gas production and, therefore, was not expected to stimulate it, a stress test to determine the minimum in-situ stress and to estimate the stress ratio would be performed. Otherwise, minimum stress and stress ratio normally would be estimated from the operator's stimulation results. The second type of well test consisted of conventional transient drawdown/build-up testing.

Two different basic procedures were used to determine the in-situ stress(es) for the formation; one utilizing the more conventional approach of injecting water into the formation at a pressure higher than the in-situ stress value and then observing the pressure during shut-in/leakoff to determine fracture "closure" pressure; and the second utilizing nitrogen injection into the well/formation while monitoring rates and pressures. By doing a mass balance on the nitrogen injected into the well, it was possible to determine at any given time the actual rate of injection into the target formation. By comparing these rates to the wellbore pressure, "parting" and/or closure pressures would be determined for the formation. 
Conventional transient well tests wele conducted on each well with one basic design custom-tailored to the specific well, depending on a number of factors such as time available for testing, maximum anticipated pressures, and anticipated liquids production. There there was little or no ilatural production, a small stimulation was sometimes performed to overcome the local weilbore "skin"; i.e., to assure that the wellbore was in communication with whatever natural fracture system was present in the formation. This small stimulation would consist of either a small volume of nitrogen or a small volume of water injected at a pressure high enough to "break down" the formation. No proppant was included in these "mini fracs". After the well was completed, including the mini-frac, if required, the well would be shut-in and allowed to build up to a relatively stable pressure before beginning the constant rate drawdown test. After one to two weeks of drawdown, the well would be shut in for build-up. Pressures were normally measured at the wellhead and then corrected to bottomhole values unless liquids production was anticipated. Correction of wellhead pressures to the corresponding bottomhole values was simplified by the typically-low mass flow rates during drawdown which allowed the assumption of a constant wellbore temperature profile. Typical well and surface equipment configurations are as shown in Figures 3-1 and 3-2 for the A.B. Wilson \#19 well in Wirt County, WV.

\subsection{Procedures and Analyses}

\subsubsection{Core Analysis}

After the initial examination of the core and the identification of samples for petrographic testing, fractographic analyses were conducted on the cores. The procedures for logging the fractures in the core were the same as those developed by Kulander, Barton and Dean (1979). Those procedures consisted of the visual observation and measurement of rock fractures and features which were applied to determine: 
A. B. WILSON * 10

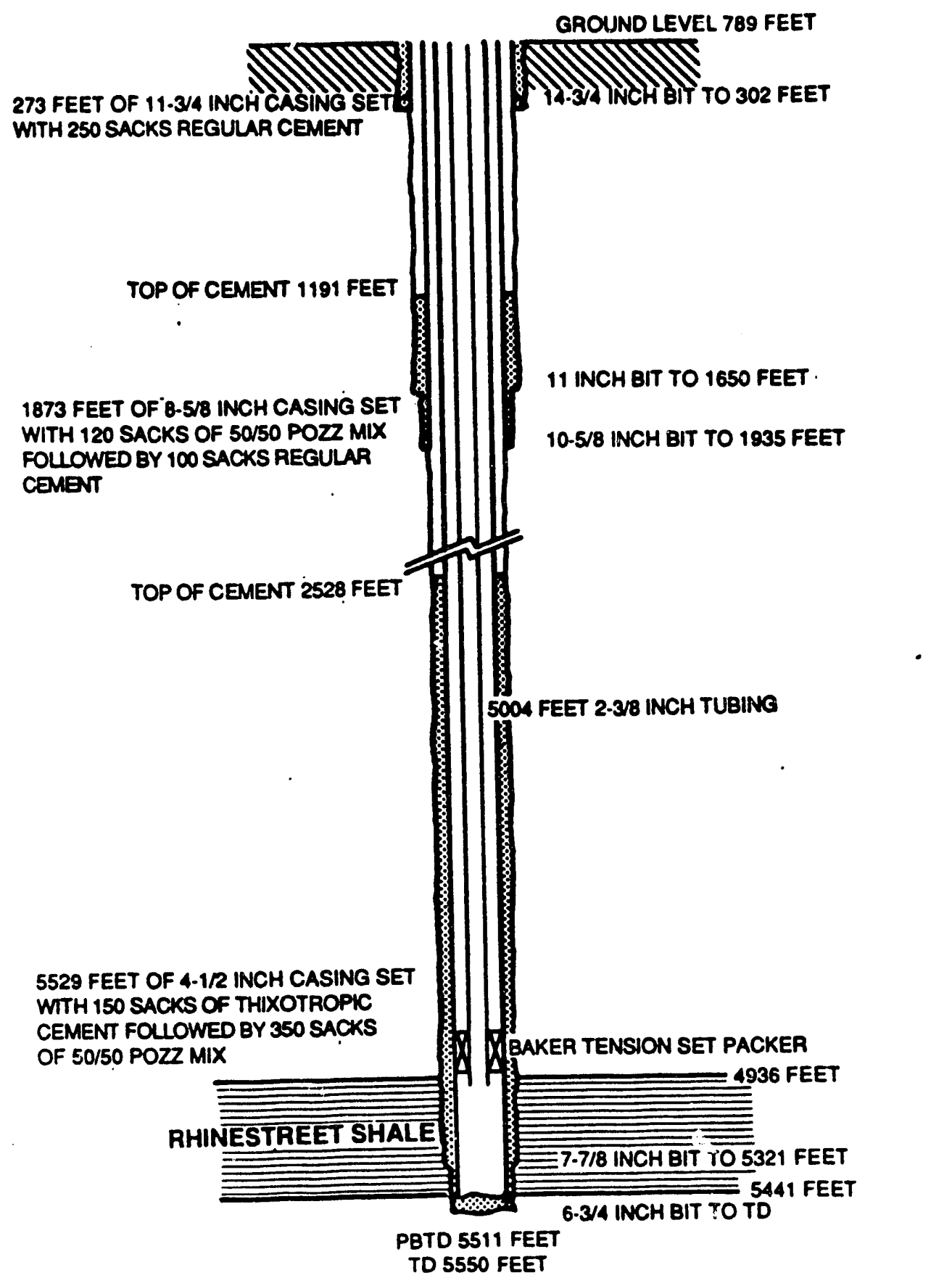

Figure 3-1. Typical Well Set-up for Production Testing 


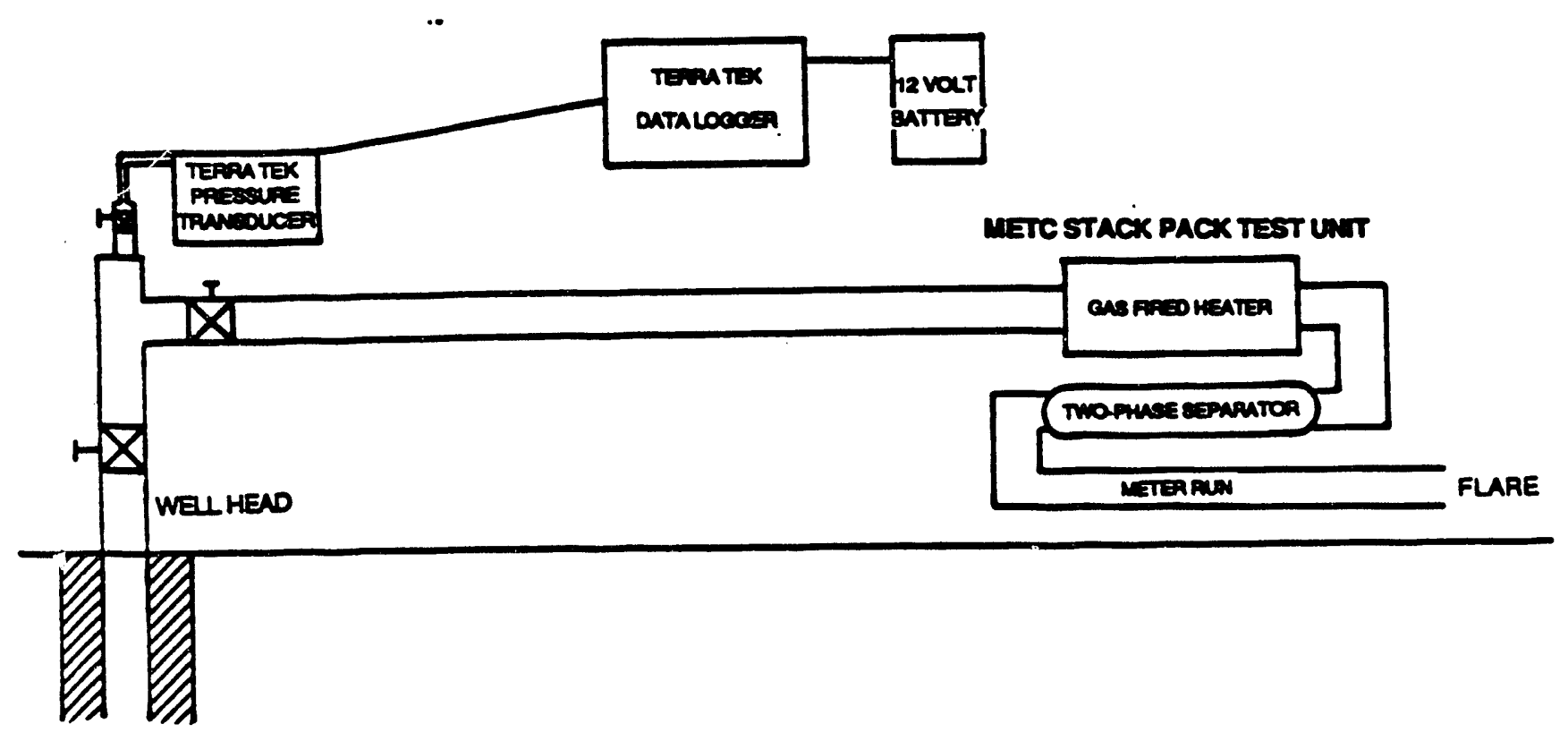

Figure 3-2. Typical Surface Facilities for Production Testing (A.B. Wilson \#19) 
1) natural fracture orientation;

2) mesoscopic tectonic fractures such as faults, sylolites, slickenlines, and mineralization trends;

3) coring-induced fractures and their type, frequency, orientation and extent;

4) possible in-situ stresses and/or rock anisotropies indicated by coring-induced fractures.

The core samples which had been placed in canisters at the wellsite were shipped to Waynesburg (PA) College, where extended "outgassing" of the cores was carried out. The procedure utilized canisters similar to those developed and used for coalbed methane desorption. Readings of the gas liberated were taken at approximately 15-minute intervals for the first two hours and then daily for the first week. Periodic readings continued for several months until essentially all gas had been released from the samples. Taking frequent readings of gas liberated by the samples immediately after core recovery allowed for making an estimate of the gas lost during drilling. This method used is similar to that used by the U.S. Bureau of Mines technique (Kissel, et al, 1973). The data coilected irom the off-gassing measurements were used to determine the volume of lost and desorbed gas and to provide some measure of the shale's gas reserve.

For each well, samples of desorbed gas were collected from two canisters and analyzed by gas chromatography. Those two canisters had been flushed with helium at the time the samples were enclosed in order to remove extraneous gases. Helium was used because it was the carrier for the gas chromatography. All gas chromatographic data were obtained using a Hewlett Packard Model 5750 Research Chromatograph equipped with thermal conductivity detector and integrator. Methane, oxygen, and nitrogen concentrations were obtained using a 12-font 60/80-mesh Molecular sieve $(5 \mathrm{~A})$ column heated at $140^{\circ} \mathrm{C}$ and a helium flow rate of $25 \mathrm{ml} / \mathrm{min}$. Carbon dioxide, ethane, propane, isobutane, and butane concentrations were obtained using a 10-foot 80/100-mesh Poropak- $R$ Column with the temperature programmed from $40^{\circ}-140^{\circ} \mathrm{C}$ at a rate of $30 \mathrm{C} / \mathrm{min}$. 
The helium flow rate through the column was $27 \mathrm{ml} / \mathrm{min}$ at $40^{\circ} \mathrm{C}$. Petrophysical analyses were conducted on the cores to determine:

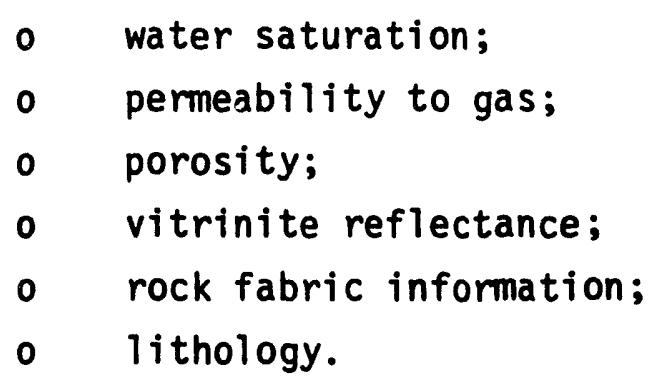

Typically, six samples were analyzed for each core (one sample for each 10 feet of core). The samples were protected during shipping by wrapping them in plastic wrap and sealing them further in a rlastic bag. The samples, when received by Petrophysical Services, were slabbed lengthwise and cylindrical plugs, approximately 1-1/2 inches in diameter and one inch 1ong, and 3/4-inch slices were obtained from one set of slabs. The pluigs were used for porosity and permeability testing. Several of the slabs were sent to Core Laboratories in Dallas, Texas, for vitrinite reflectance and a detailed lithologic and rock fabric description.

Plug samples were vacuum oven dried at $40^{\circ} \mathrm{C}$ until weights were constant to within 0.01 grams in 24 hours. Weight change of the preserved core, together with water density data, were used to calculate as-received water saturation. Samples were cooled to $25^{\circ} \mathrm{C}$ in a desiccator and porosity was determined by a helium gas expansion technique.

Following porosity measurements, plug samples were placed in a humidity oven at $65^{\circ} \mathrm{C}$ and 45 -percent relative humidity until sample weights were constant to within 0.01 grams in 24 hours. Weight gain in the samples was used to calculate equilibrium water saturation. The plugs were then installed in the gas permeameter and the gas permeability was determined at specified stress conditions by the transient-pulsedecay technique. The three stress conditions were chosen to be approximately equal to $0.5,1$, and 2 times the assumed reservoir overburden stress. 
Thin-section petrography and Scanning Electron Microscopy with Energy Despersive Spectroscopy (SEM/ED) analysis were conducted to determine:

- megascopic features, fabrics, and textures;

o silt, matrix, cement, and clay compositions and abundances;

o types, amounts, and distribution of porosity;

o estimation of reservoir quality;

- occurrences of potential problem minerals;

- possible mineralogic effects on completion, production, enhanced recovery, and wireline logs; and

- general recommendations to circumvent or mitigate these possible difficulties.

Energy Dispersive Spectroscopy provided qualitative elemental analysis of mineral phases and aided in the identification of framework grains, cements, and matrix materials observed by SEM. For the Scanning Electron Microscopy/Energy Dispersive Spectroscopy Study, the samples were broken down to form fresh surfaces. Each sample was mourited on an aluminum slab and coated with a thin film of gold-palladium (Au-Pd) alloy using an ISI-PS2 Coating Unit. The sample was analyzed using an ISI-SX-40 Scanning Electron Microscope. Qualitative EDG analyses were made with a PGT System III Energy Dispersive Spectroscopy Unit equipped with an $S i(L i)$ detector. Spectra were taken with an electron beam accelerating potential of $20 \mathrm{kV}$.

Thin section petrography allowed determination of rock textures, framework-grain composition, cement composition and texture, and porosity characteristics. Modal point-count analyses provided quantitative volume percentages of the constituents of the rock. Thin-sections were prepared by first impregnating the sample with epoxy to augment sample cohesion and to prevent loss of material during grinding. A blue dye was added to the epoxy to highlight the porosity. Each sample was mounted on a glass slide and cut and lapped in water to an approximate thickness of 30 microns. Samples containing known water-soluble phases 
were prepared using odorless kerosene. Prepared thin-sections were subsequently stained for calcite (Alizarin Red-S stain), ferroan calcite, ankerite (potassium ferricyanide stain), and potassium feldspar (sodium cobaltinitrate), as necessary. The thin-sections were analyzed using standard petrographic techniques. Modal analyses of thin-sections were performed by the point-count method ( 400 points/samples) using a Swift Model F Automatic Point Counter.

Core material not used for cesorption testing or petrophysical analysis was shipped to Michigan iechnological University for mechanical characterization. The primary of this characterization study was to determine the orientation of preferred planes of weakness. Physical properties tests included:

- Directional Ultrasonic Velocity.

- Point-load Induced Fracturing

- Directional Tensile Strength

In addition, all "pretest fractures" were systematically recorded before the physical property tests were performed. This consisted of observing and recording al? visible fractures that occurred on the sanded ends of each test specimen and provided information on natural microcrack orientation and on induced crack orientations originating from the core orientation grooves.

UTtrasonic velocity measurements were conducted as another measure of the preferred orientation of microfractures in the samples. Fractures oriented perpendicular to the direction of wave propagation impede the wave; whereas fractures oriented parallel to the direction of wave propagation do not. To detect these differences, measurements were performed diametrically on each core sample at 30 degree intervals from true north. Minimum values of sonic velocity occur in azimuths normal to the preferred direction of microfractures (Komar and Kovach, 1969).

Point load induced fracture tests were conducted on 2-inch diameter by 0.5 to 0.8 -inch thick undercored and surface-ground samples taken at 6 -inch intervals. The point loads were applied to each specimen using a test apparatus consisting of a load frame with two 
identical conical platens. These platens were applied so that the apical contact points were located on the center of the disk-shaped specimen. Fractures induced by a point load would be randomly oriented if the rock specimens contained no preferred planes of weakness; however, if the specimen were anisotropic, the induced fracture would be expected to occur in a preferred direction, parallel to pre-existing microfractures. Therefore, in the case of an anisotropic rock body, such as one containing a network of natural microfractures, the statistical analysis of a large number of point-load-induced fractures would show a direction parallel to the natural preferred microcrack orientation.

The directional tensile strength was found by applying a compressive diametric loading across a series of cylindrical specimens oriented in various directions (Mellor and Hawkes, 1971). In this diametric or line load test, tensile strength normal to the axes of loading was determined from the magnitude of the applied load at failure by the following formula (Peng and Ortiz, 1972):

$$
S T=2 P /(\pi d t)
$$

where: $S T=$ tensile strength, psi

$P=$ applied load at failure, ib

$d=$ diameter of disc, in.

$t=$ thickness of disc, in.

\subsubsection{Log Analysis}

The use of conventional electric log analysis to generate reserve estimates or to predict potential flow rates is almost meaningless because of the "tight" nature of the shale, the physics by which gas is contained within it, and the mechanism by which the gis is releas:d. Additionally, the porosity and resistivity $\log$ responses are affected by the presence and type of shale and, although techniques have been significantly improved during the past few years, interpretation still remains somewhat of an art in high shale percentage intervals. A high degree of local experience is often required to be economically successful in interpreting logs in zones having high shale content. Therefore, 
a "micro" interpretation of the electric logs over the target shale section was performed to identify probable fractures, gas entry points, etc. It was often found that even the most subtle cooling trends on the temperature $\log$ could be correlated with zones of apparent porosity or changes in resistivity, organic content, or uranium content. These findings were compared with the fractographic $\log$ and the detailed core description, where available, to generate a more complete evaluation to determine points where the Devonian shale gas entered the wellbore naturally.

Analysis of the video camera $\log$ also was more qualitative than quantitative in that while gas entry points sometimes could be detected, there was no way to determine the flow rate of gas entering the wellbore. Also, fractures were sometimes visible, but orientation was not possible. Where the fracture's wellbore signature was adequate, the fracture would be oriented by one of the two following methods:

- Vertical fractures with two obvious entry/exit points were oriented by comparing the line represented by these two points to the compass rose of the (usually) magnetic compass carried and visible in front of the camera.

- Vertical or nearly vertical fractures subparallel to the wellbore and having an upper and/or lower exit point (i.e., where the fracture completely exits the wellbore) were oriented by comparing the exit point to the compass rose. An upper exit point would represent the updip orientation while a lower exit point would be downdip. The fracture's strike would be perpendicular to the dip orientation.

0il/water stains visible with the video camera were also noted as positive indications of fractures or other permeability features.

\subsubsection{Well Test Analyses}

Well test analysis procedures varied slightly from well to well, depending on the exact circumstances; however, the general approach became more or less standardized for the typical constant rate 
drawdown/build-up test sequence. This standard approach utilized loglog plots of pressure or pseudopressure versus time to determine flow regimes (wellbore storage, linear flow, radial flow) and to make initial estimates of reservoir properties. Semilog plots were then utilized to refine the estimates of reservoir properties. Simulation of test results was then used to further refine the results, especially where unusual conditions were detected; e.g., where rates varied significantly or where wellbore storage varied.

Preliminary data analysis typically consisted of separately collecting wellhead gauge pressure and meter run differential pressures and matching teh two data sets on the same time scale. Wellhead pressures were first converted to absolute pressure and then to bottomhole pressure using the Cullender and Smith algorithm (Frick, 1961). Gas meter run parameters were converted to flowing rates using the orifice meter procedure. Figure $3-3$ is an example comparing wellhead to bottomhole pressure.

The accuracy of transient analysis of compressible gas systems is enhanced for certain pressure ranges if the real gas potential or pseudo pressure is used. A graph of pseudo pressure versus bottomhole pressure was constructed using the following equation:

$$
\text { Pseudo pressure }=2 \int_{P_{b}}^{P} \frac{P}{\mu(P) Z(P)} d p
$$

$$
\text { where: } \begin{aligned}
\mu & =\text { gas viscosity } \\
Z & =\text { gas compressibility factor } \\
P & =\text { pressure } \\
P_{b} & =\text { base pressure. }
\end{aligned}
$$

The viscosity and compressibility factors were taken from correlations using gas composition or gas gravity. A typical pseudo pressure graph is shown in Figure 3-4. Pressure points used in the well test analyses were readily converted to pseudo pressure points using graphs such as this one. 


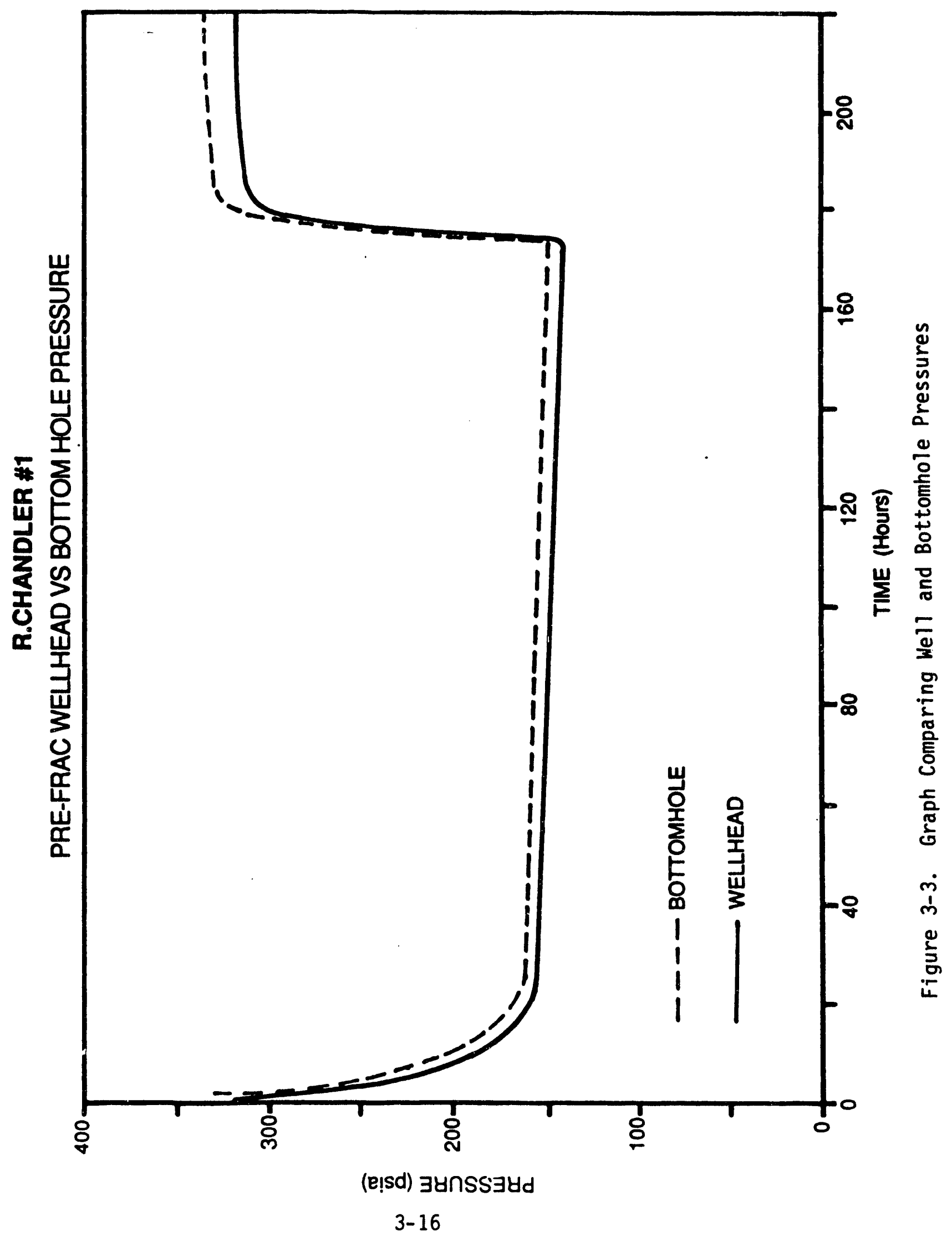




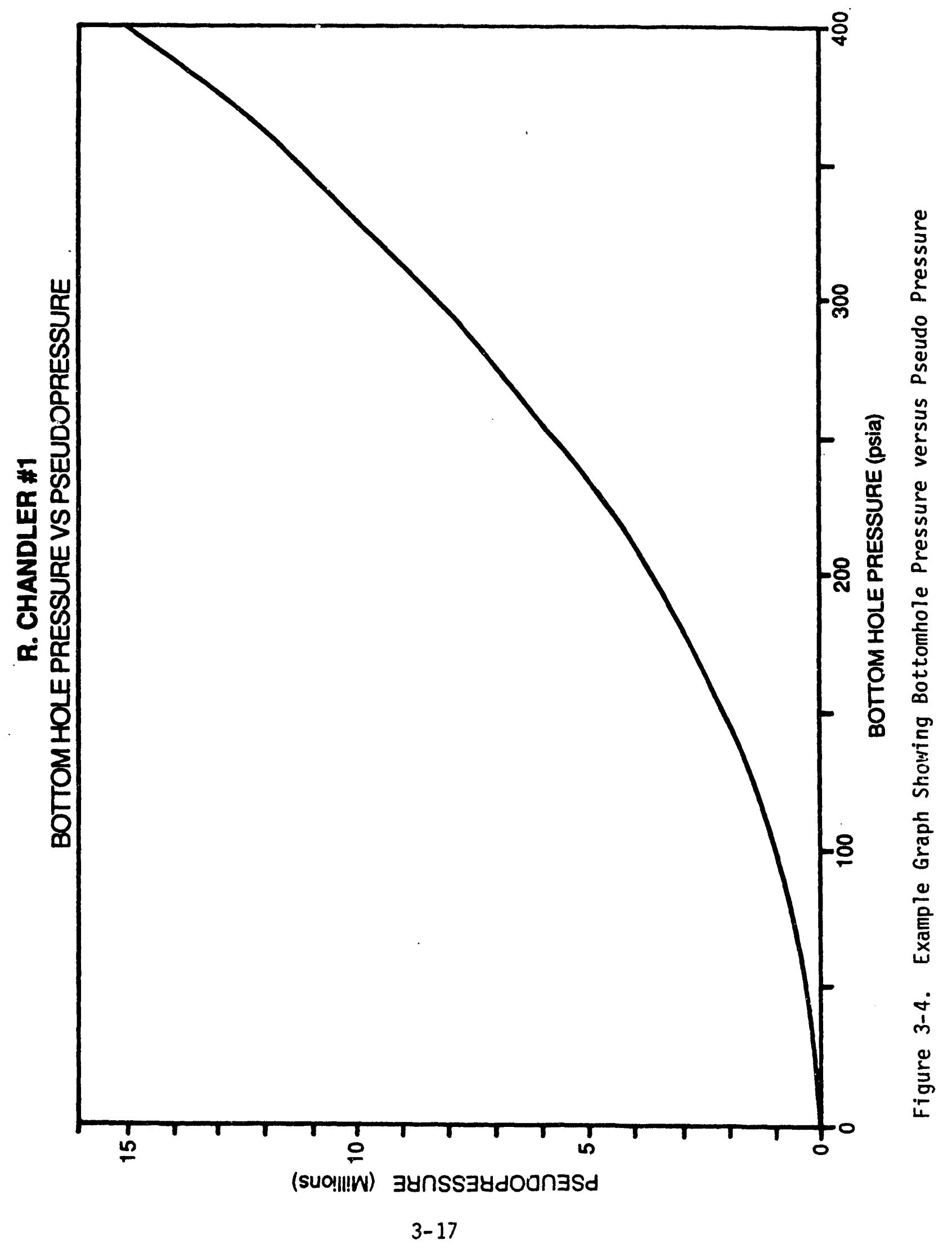


At the beginning of any production test the subsurface flowing rates are greatly influenced by the amount of gas or liquid stored in the wellbore. Actually, all initial production originates within the wellbore volume and there is a finite period of time that elapses before subsurface or "sandface" flow predominates. This phenomenon is wellbore storage distortion. Therebore, it was necessary to characterize flow regimes including wellbore storage encountered during production and build-up tests.

Figure 3-5 is an example of a plot of the $\log$ of pseudo pressure change versus log production time. Plots such as this will sometimes show three distinct patterns for a well. These patterns include:

(1) Initial early time slope $=1.0$, indicative of wellbore volume loading/unloading;

(2) Middle time region slope $=0.5$, indicative of linear flow from a fracture, if one exists;

(3) Late time region slope breaking convex, indicative of radial reservoir flow.

As can be seen in this esample, any wellbore distortion appears to have ceased by the point of log time $=0.52$ (time $=3.32$ hours). Little or no half slope was evident in this example, perhaps until log time $=0.80$ (time $=6.31$ hours). The well had not been stimulated at this time, therefore, the curve is probably more representative of radial flow rather than linear flow into a fracture.

For a constant rate test, a semi-log plot of pseudo pressure versus the $\log$ of production time exhibits a straight line proportional to formation permeability. Figure 3-6 illustrates such a plot. For a constant rate flow test, wellbore storage can be expected to influence well test pressure response until 1 to $1.510 \mathrm{~g}$ cycles after the end of the unit slope line of Figure 3-5. Therefore, only the points after $\log$ of time equal to approximately 1.6 on the semilog plot in this example would be considered valid. Formation permeability is related to the slope from the semilog plot by the following equation:

$$
K=\frac{1636.36}{m h} T q g
$$




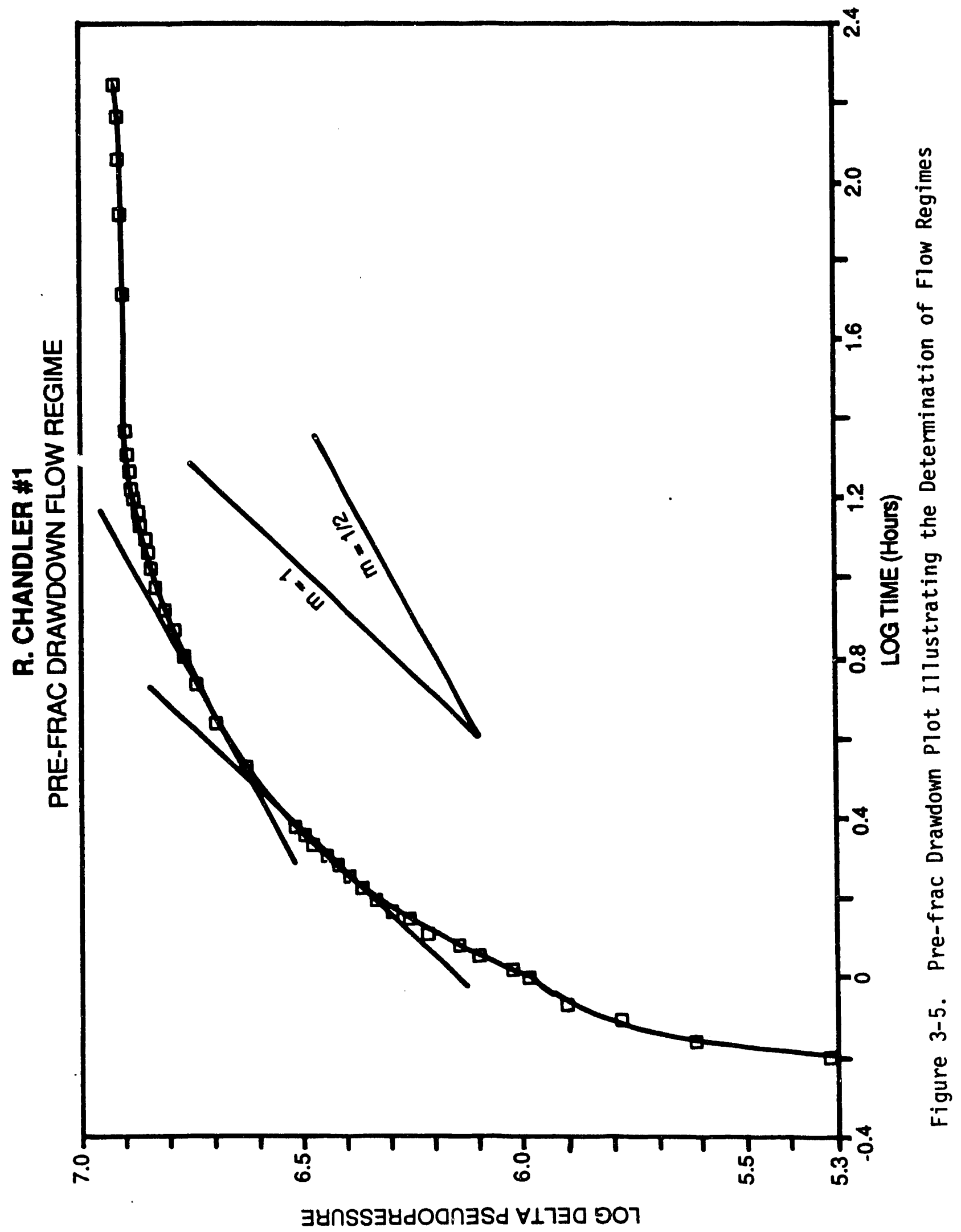

3-19 


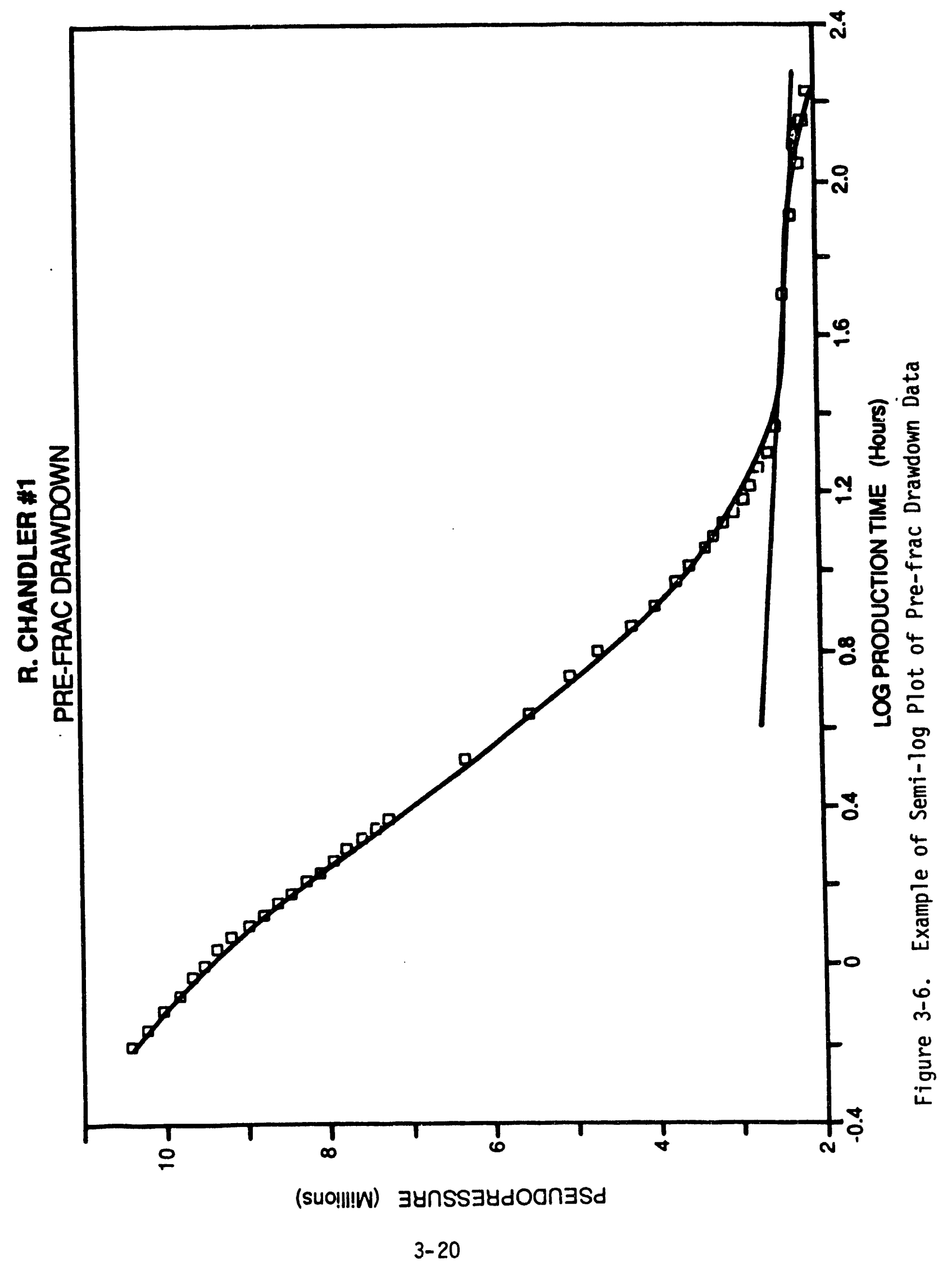


Similar analyses were conducted on the build-up phase of the tests, again using log-log type-curve analysis first, and then plotting pseudo pressure versus the log of Horner time on a semilog plot to obtain better reservoir parameter values. Figure 3-7 illustrates the Horner time semilog plot for build-up analysis. 


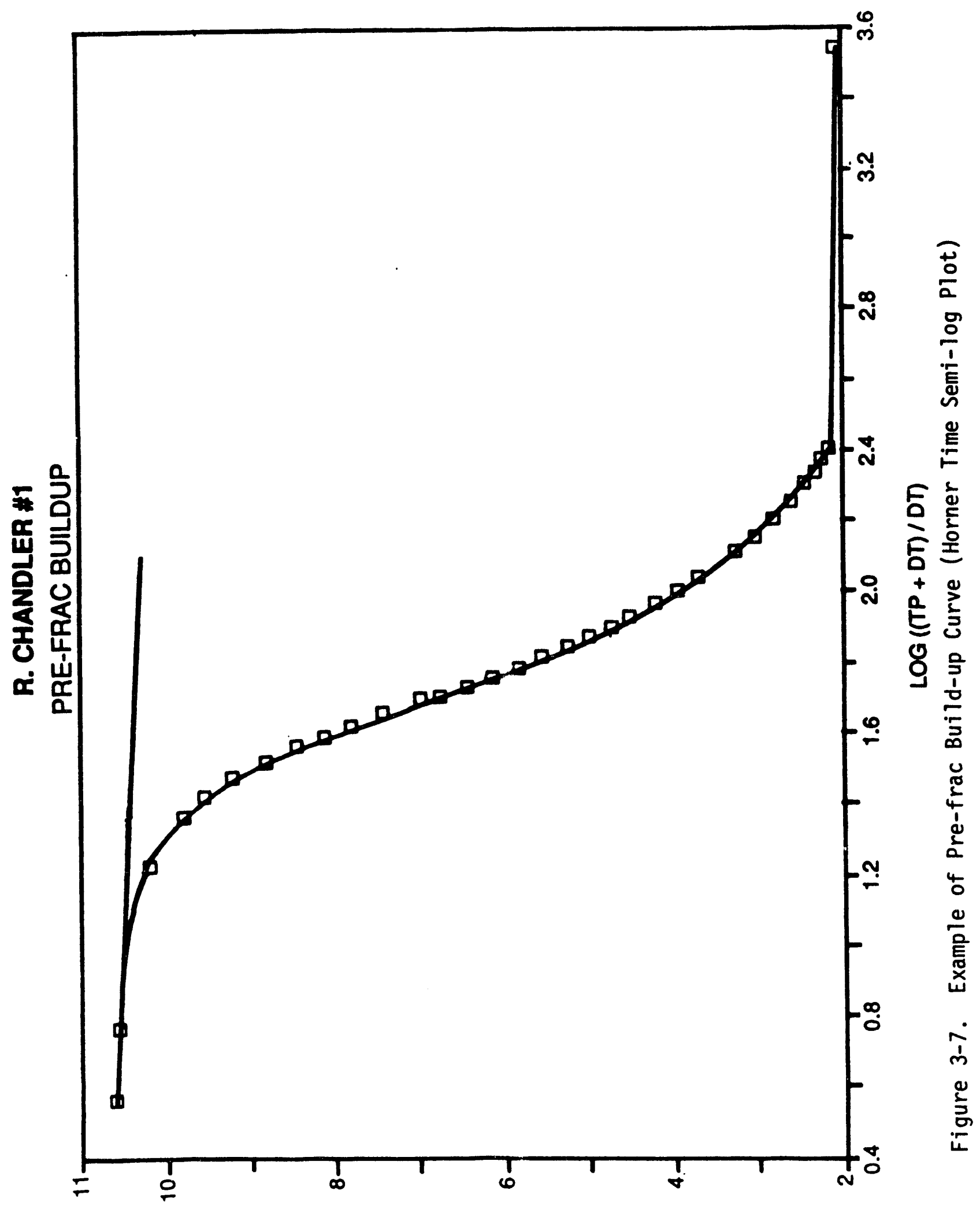

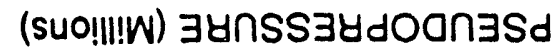




\subsection{OFFSET WELL TEST FACILITY}

The Offset Well Test Facility was established adjacent to the Raymond Chandler, et al, No. 1 well in Whitley County, Kentucky. The Chandler No. 1 met the most significant of the contract-specified selection criteria (see Section 2.0) and presented an opportunity to obtain detailed reservoir information on the Chattanooga shale in an area that previously had not been investigated.

This section presents a summary of the activities conducted at the Offset Well Test Facility. Section 5.0 presents the findings that were derived from these activities. Detailed information concerning specific tests, stimulation treatments, and geological factors are provided and/or have been provided previously in the form of raw data, subcontractor reports, the individual well report for the Raymond Chandler No. 1 well, and a separate activity report for Phase II of the contract.

\subsection{The Test Site}

The choice of the Whitley County, Kentucky, site adjacent to the Raymond Chandler No. 1 well for the Offset Well Test Facility was approved by the U.S. Department of Energy in January, 1987. Negotiations for the site were finalized between BDM and Alpha Gas Development, the principal owner and operator of the lease, in April 1987. Approval of the agreement and authorization to proceed was given by the Department of Energy in July, 1987. The first offset well was spudded at the site on September 7, 1987.

The initial well pattern chosen for the site was based on rock mechanics information conducted by Michigan Technological University on the core taken from the Chandler No. 1 and is shown in Figure 4-1. Rock mechanics data indicated that the most probable orientation of an induced hydraulic fracture was $N 20^{\circ} \mathrm{E} \pm 10^{\circ}$. To minimize the probable effect on test results of the induced fracture already existing in the Chandler No. 1 well, and to take advantage of the probable permeability orientation, the pattern was aligned so that the Chandler No. 1 was 


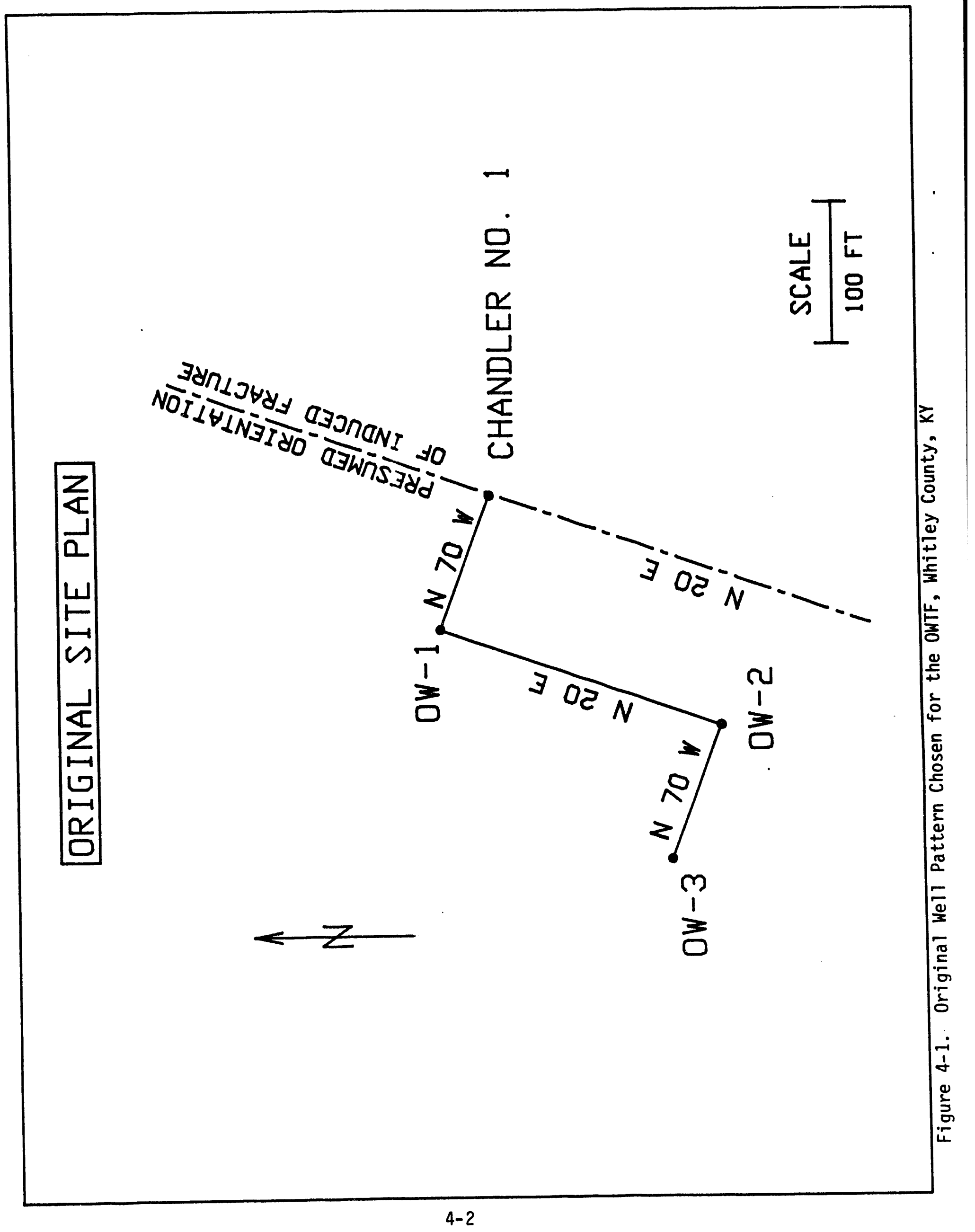


approximately 100 feet away on a line bearing approximately $S 70^{\circ} \mathrm{E}$ from Offset Well No. 1. Offset Well No. 2 was approximately 200 feet away on a line bearing approximately $520^{\circ} \mathrm{W}$ from offset No. 1. Offset Well No. 3 was approximately 225 feet away on a line bearing approximately $547^{\circ} \mathrm{W}$ of offset No. 1 and approximately 100 feet away and on a line approximately $\mathrm{N} 70^{\circ} \mathrm{W}$ from offset No. 2 .

During the drilling of the first offset well (Well \#OW-3 in Figure 4-1), commercial quantities of gas were discovered in the "Big Lime" formation, approximately 500 feet above the target Devonian Chattanooga Shale. Because of the high volumetric flow rate from the Big Lime, it was agreed that Alpha Gas Development would take over the well and complete it in the Big Lime. Rather than to risk damage to the Big Lime well and/or create a safety hazard by drilling the well deeper to the target zone, the well pattern was altered and new well locations for the offset wells were selected. The revised pattern was shifted to the opposite side of the Chandler No. 1 well in a mirror image of the original pattern (see Figure 4-2).

All of the wells in the pattern were gyroscopically surveyed to determine the actual bottomhole locations of the wells for use in reservoir calculations. The resulting bottomhole well pattern is shown in Figure 4-3.

\subsection{Field Operations}

The major field operations at the offset Well Test Facility site consisted of the drilling and completion of the three offset wells, testing the wells individually, pulse-testing between the pattern wells, conducting longer-term interference tests, conducting a limited-entry foam-frac stimulation of offset Well No. 3, conducting a tiltmeter study of the site during the foam-frac, conducting post-frac tests, recompletion (dual completion) of offset Wells No. 1 and No. 2 in the Big Lime as part of an effort to assess interference between Big Lime production and Chattanooga shale production, and pulse-testing the Big Lime between pattern wells. 


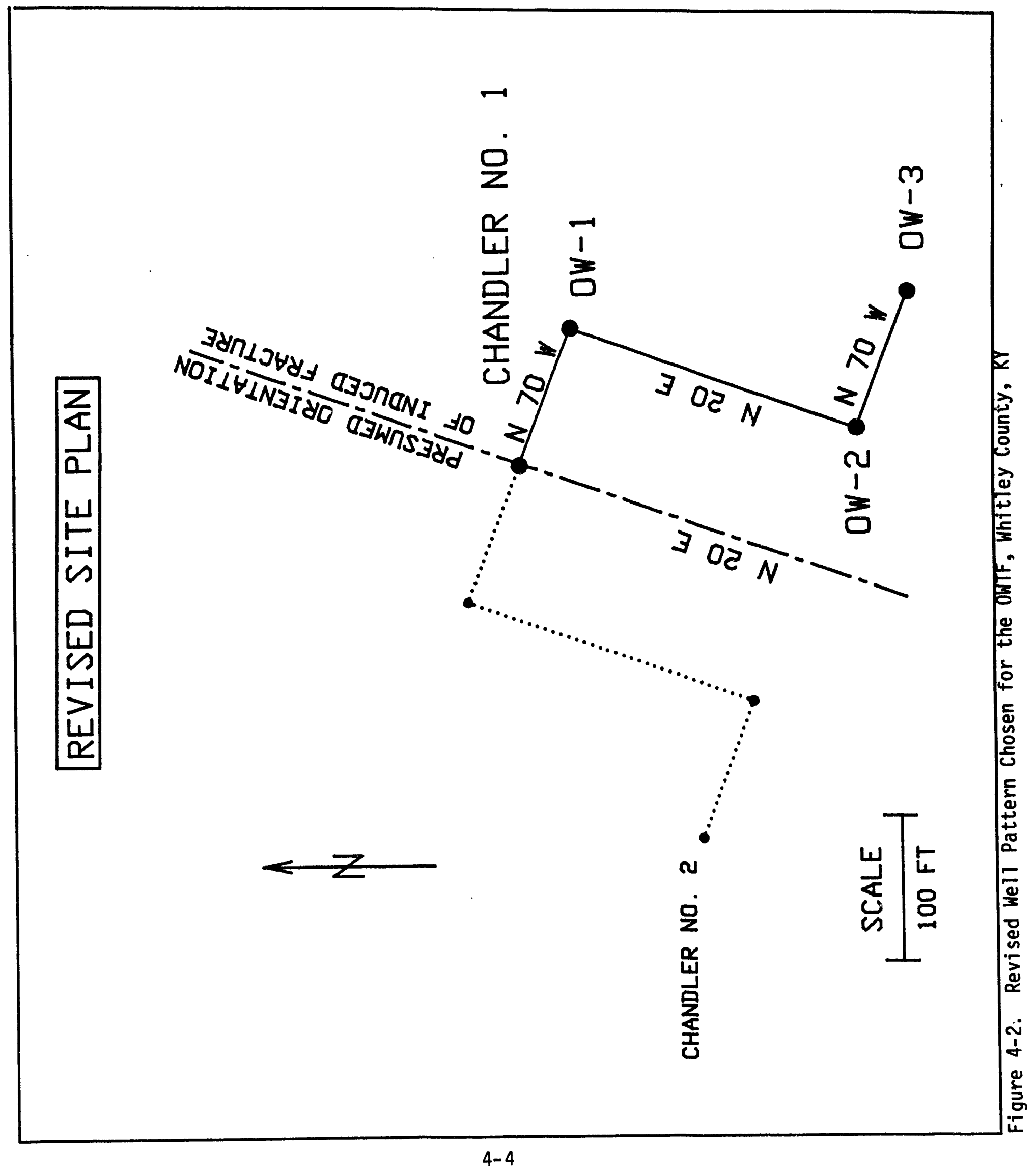




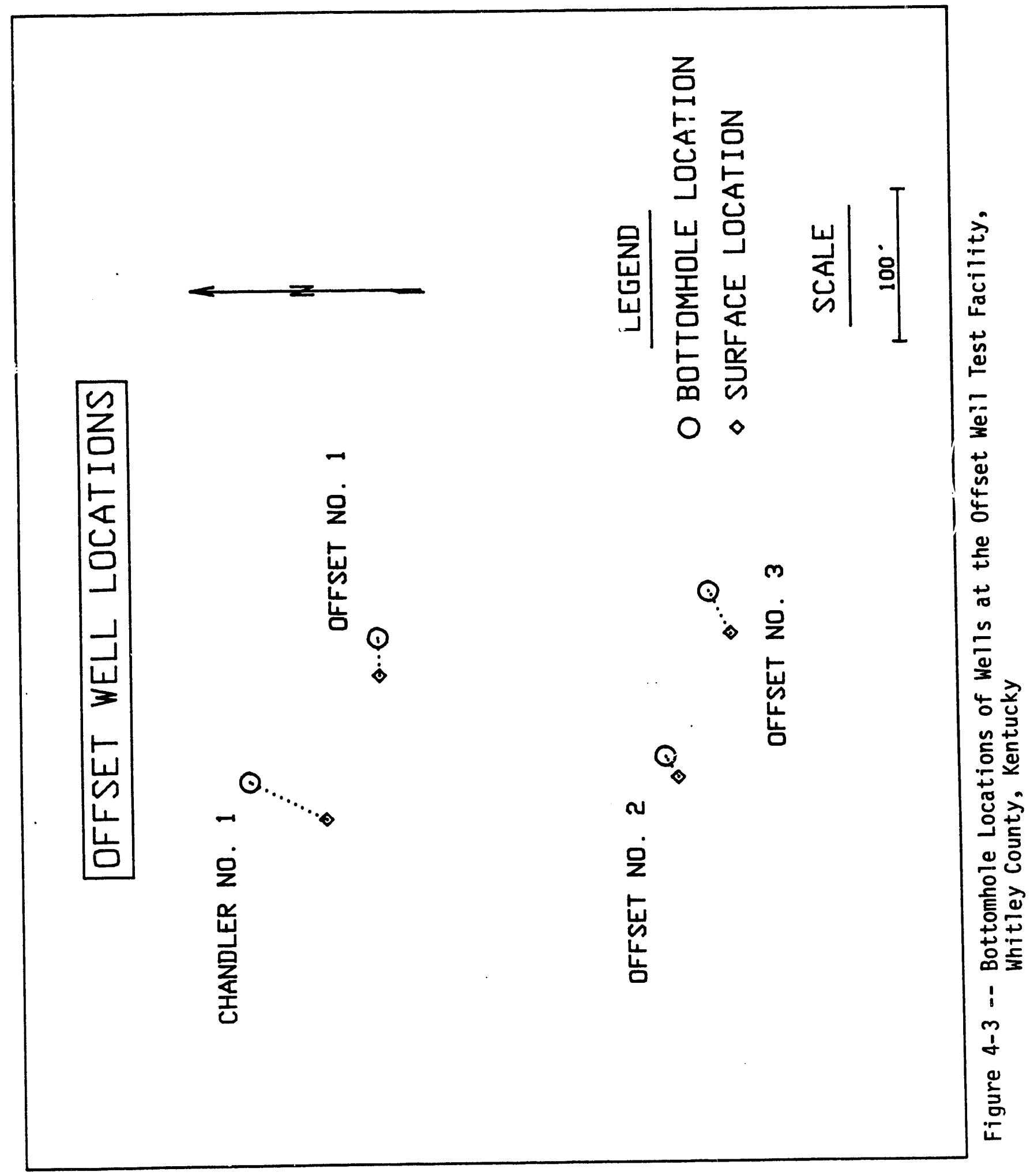




\subsubsection{Drilling and Completion Activities}

The first of the three offsets, designated as offset Well No. 3, was drilled and completed in September, 1987. The well was drilled on air to a depth of 2102 feet, logged, and pulse-tested in conjunction with the Chandier No. 1 well to determine whether or not there was any potential for a direct or nearly-direct connection with the induced frcture in the Chandler No. 1. The pulse test was conducted because future plans called for stimulating Offset Well No. 3 and this would be the final opportunity to revise the well pattern. No evidence of a direct connection was found. The well was completed initially "open hole" with a packer set on tubing at the top of the Chattanooga shale. Initial open flow potential for the well was approximately $20 \mathrm{mscf} /$ day after 24 hours.

The second of the three offsets, designated Offset Well No. 1, was spudded in late September, 1987, and completed in early October. This well, located about 360 feet east-northeast of the Big Lime producing well (see Section 4.1, Figure 4-2) had a good.show of gas in the Big Lime. Offset No. 1 was completed similarly to Offset No. 3 with 7-inch casing set in the Big Lime below the gas show and the rest of the hole open through the Chattanooga. This well was also completed using 2-inch (numinal) tubing set on a packer at the top of the Chattanooga. The initial open flow from the shale in this well was only 4 mscf/day after 48 hours.

The third of the 3 offsets, designated as Offset Well No. 1, was drilled and completed in early October, 1987. This well, approximately 300 feet southeast of the Big Lime well, also had a good show of gas in the Big Lime. Offset No. 2 was also completed by setting 7-inch casing in the Big Lime below the gas show with the rest of the hole open through the Chattanooga. The well was completed for testing with 2-inch (nominal) tubing set on a packer at the top of the Chattanooga. The well completion configurations for the offsets are shown in Figure 4.4 . 


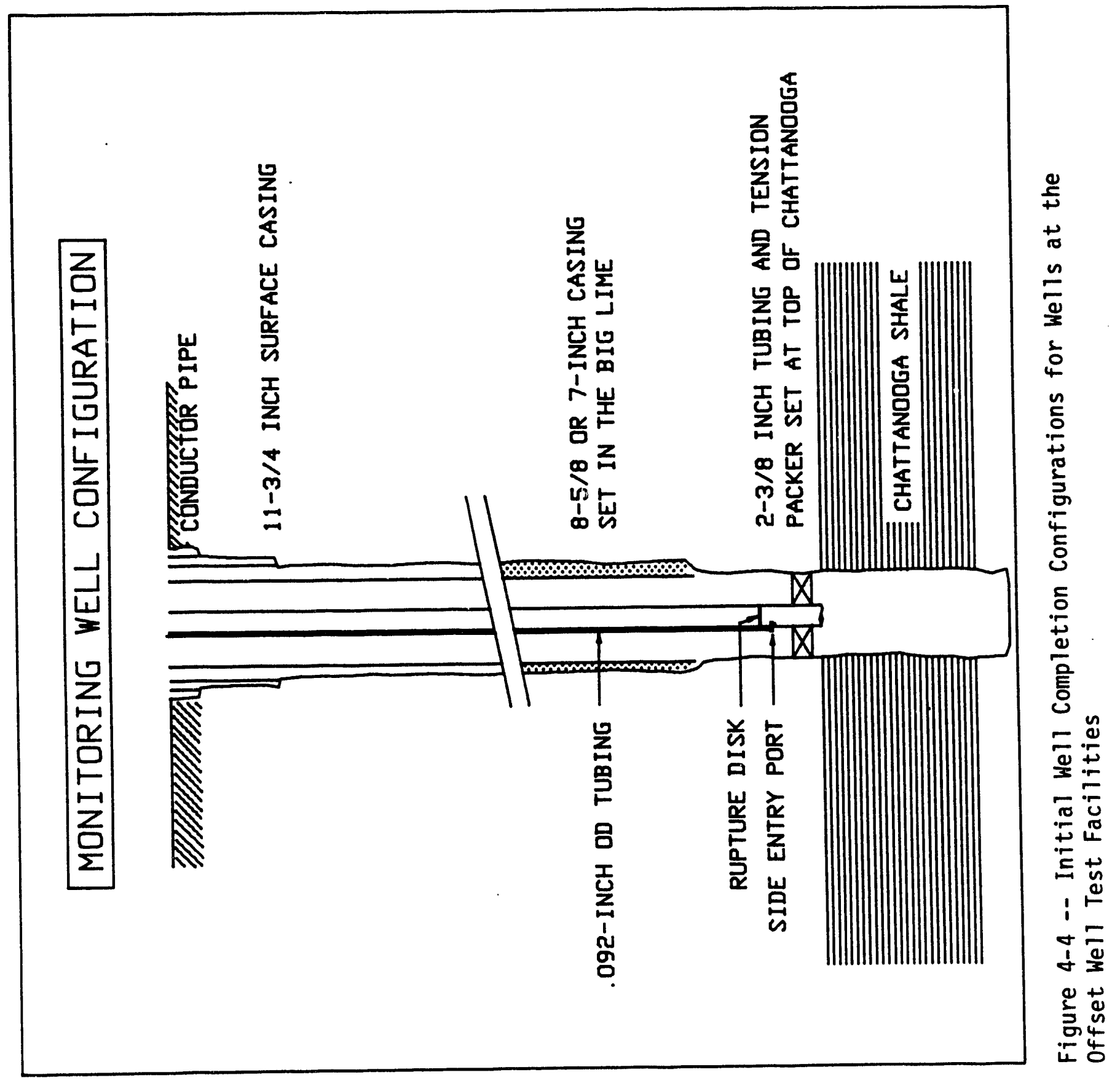


Because of the low natural production rate of 0 ffset Well No. 1, the proposed control well, a very small nitrogen stimulation was conducted on it. A total of $95 \mathrm{mscf}$ of nitrogen gas was injected at rates which were gradually increased from $1500 \mathrm{scf} / \mathrm{min}$ to $9500 \mathrm{scf} / \mathrm{min}$. Maximum pressure recorded was approximately 2000 psig (wellhead). The ISIP was approximately 1000 psig (wellhead). No measurable pressure response was recorded in either the Chandler \#1 well or on the \#3 offset during the treatment. A mechanical problem with the pressure transmission system in the \#2 offset prohibited measurement of a response in that we11. Sma11, but measurable responses were seen in both monitoring wells in as little as 45 minutes after initiation of the treatment (approximately 30 minutes after shutting down).

Figures 4-5 and 4-6 show the pressure histories recorded during the stimulation. Figure 4-5 shows the pressures of all three wells during the treatment and the next 14 hours following. Figure 4-6 shows the pressure histories for the monitoring wells on an expanded scale during the same time period. As can be seen in Figure 4-5, pressures increased by as much as 3 psi over a 6-hour period following the treatment.

\subsubsection{Offset Well Testing}

Offset wells No. 1,2 , and 3 were individually tested and analyzed utilizing the same procedures as described in Section 3.0. Two controlled pulse tests were conducted; the first utilizing the Chandler No. 1 well as the pulsed well while monitoring the three offsets, and the second test utilizing Offset No. 1 as the pulsed well while monitoring. Longer-term interference tests were conducted utilizing Offset Well No. 1 and Offset Well No. 3 as source wells. The first pulse test was carried out in late April, 1988, and consisted of two flow periods of approximately 10 hours each from the Chandler No. 1 well separated by shut-in periods of approximately 4-1/2 hours. Flow rate for the pulses was a constant 28 mscfd. Pressures were monitored at each of the offsets. Figure 4-7 is a graphical presentation of the pressure responses that occurred at the offset wells during the pulse test. Pulse amplitudes varied from 


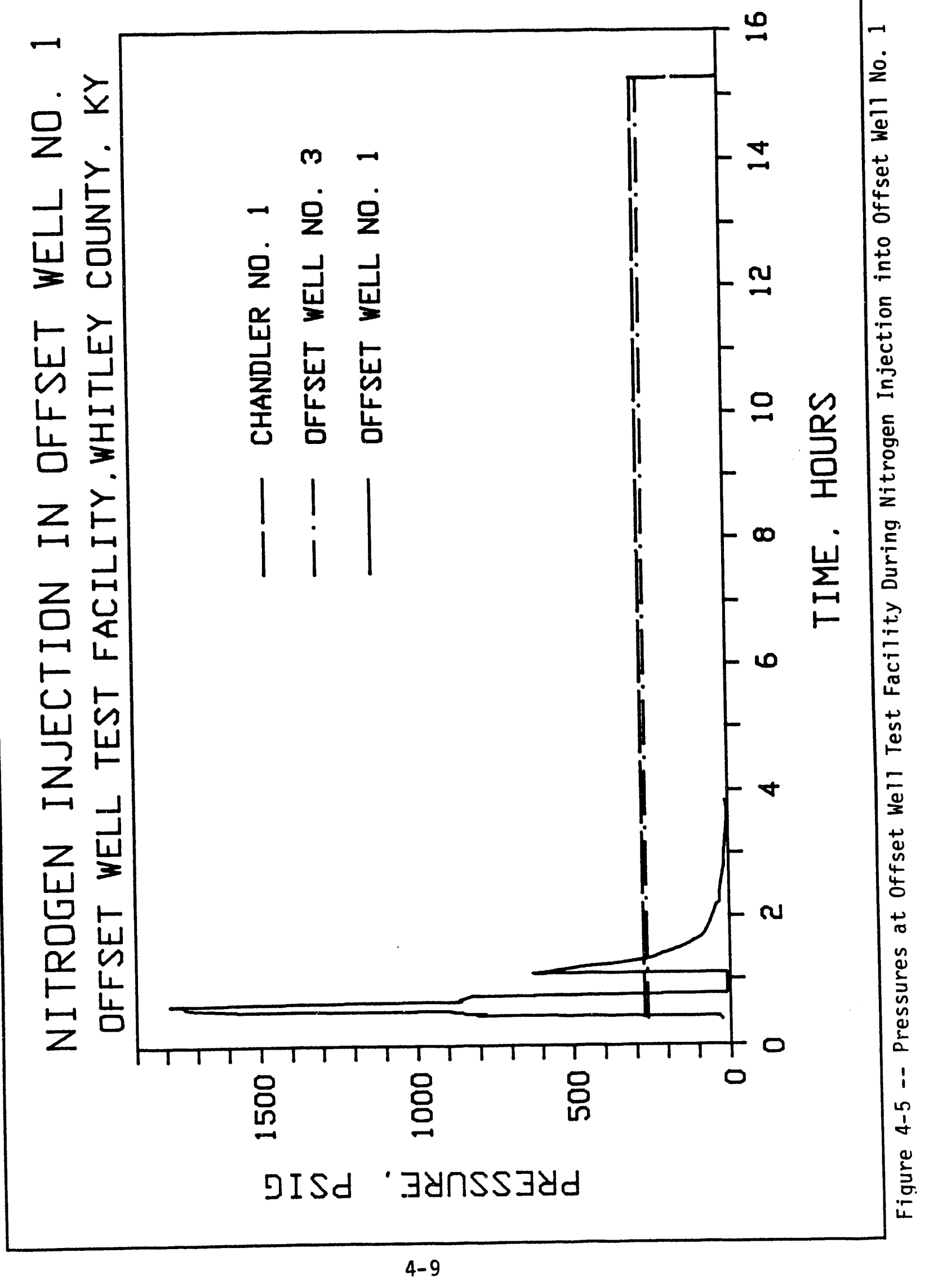




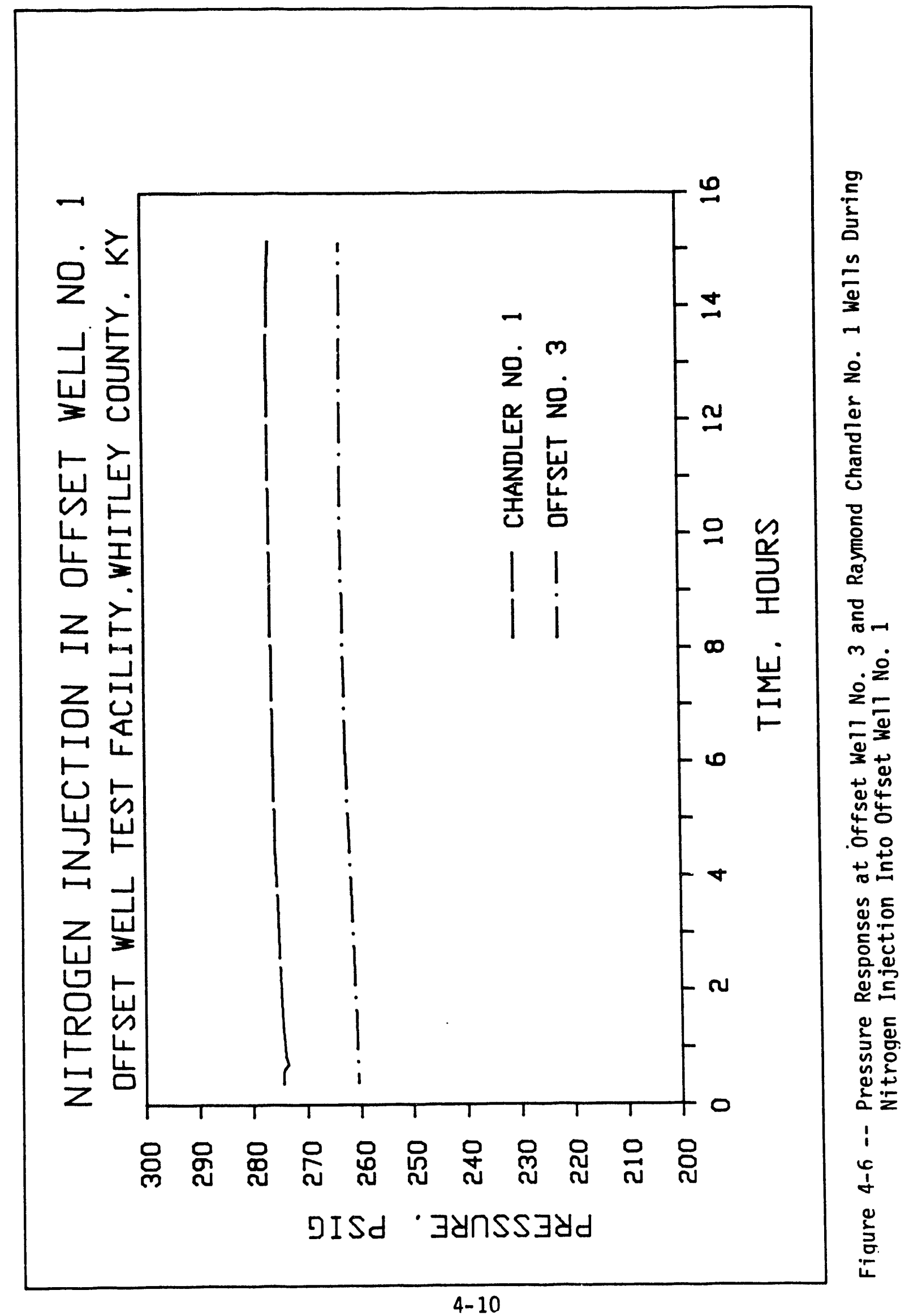



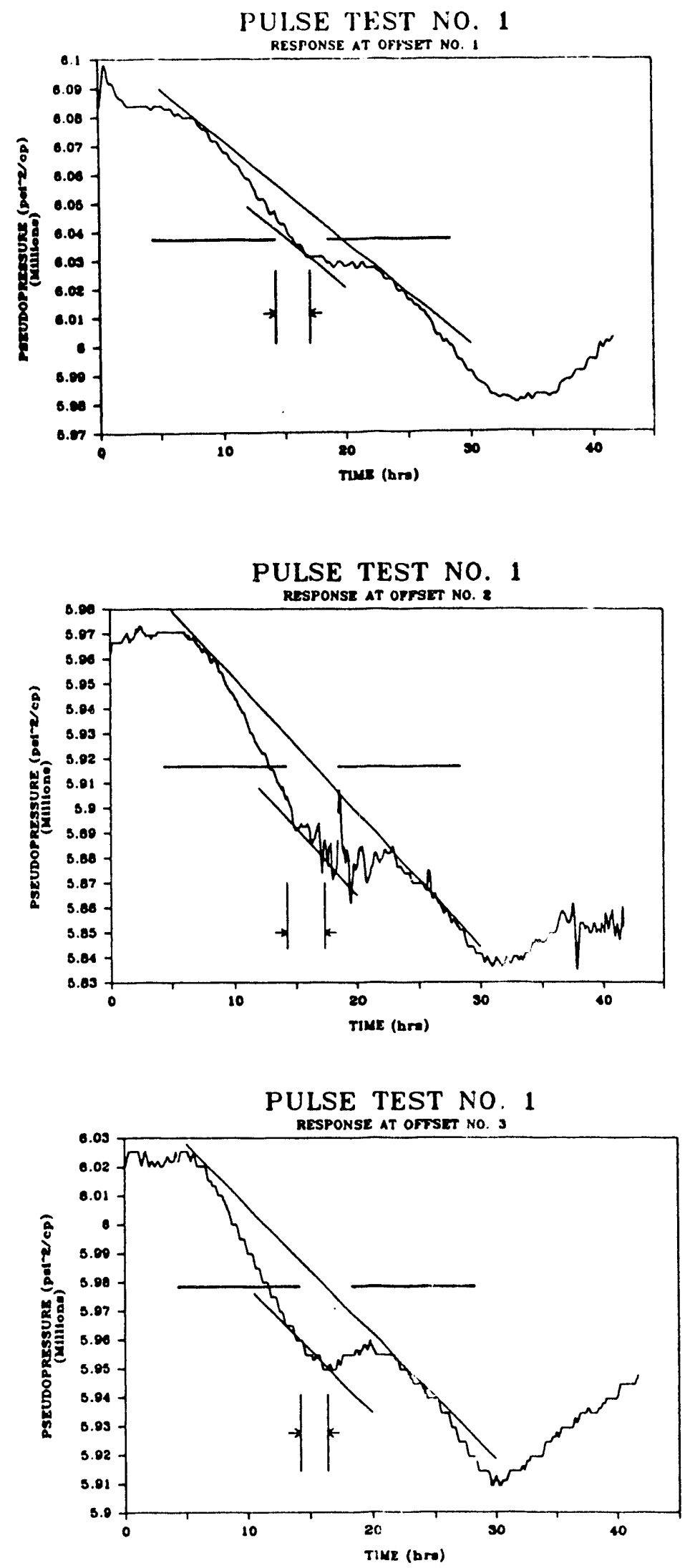

Figure 4-7 -- Pressure Responses at the Offset Wells During Pulse Testing; Pulses Applied to the Chandler No. 1 Well 
a low of approximately 0.3 psi at Offset Well No. 1 to a high of approximately 0.6 psi at offset Well No. 2. Pulse time lags, the length of time between the end of a pulse and the occurrence of maximum pulse amplitude, ranged from a low of 2.23 hours at offset Well No. 3 to a high of 3.08 hours at Offset Well No. 2. The second pulse test conducted at the site consisted of two pulses of approximately 9-1/2 mscfd applied to Offset No. 1 for approximately 10 hours each, separated by shut-in periods of approximately 4-1/4 hours each. Offset Wells No. 2 and 3 were both monitored but only offset No. 2 yielded usable data. The amplitude of responses at Offset Well No. 3 were too small for accurate analysis. Figure 4-8 shows the response at Offset Well No. 2 to the pulse input at offset No. 1 .

Interference testing was also conducted during which pressures were monitored at the site wells while one of the wells was produced and/or shut-in for a period of several days. In December, 1987, Offset Well No. 1 was flowed at a constant rate of 8.5 mscfd while pressures were monitored at Offset Wells No. 1, 2, and 3 and at the Chandler No. 1. After àproximately three weeks, Offset Well No. 1 was shut in and pressures were monitored at all wells during the build-up. Figure 4-9 shows the pressure responses observed during these tests.

\subsubsection{Foam-Frac Stimulation of Offset Well No. 3}

Offset Well No. 3 was designated to be the test well for comparing stimulation techniques. It was so-chosen because it was located farther from the Chandler No. 1 producing well than any of the other offsets; therefore, it ws probably the least likely to cause any damage or create production problems in the Chandler No. 1 . Offset Well No. 3 was also most similar to the Chandler No. 1 well in that it had very nearly the same initial open flow potential as the Chandler No. 1 , and one of the objects of this test was to compare the use of a singlestage limited entry stimulation to the two-stage treatment given to the Chandler No. 1. 


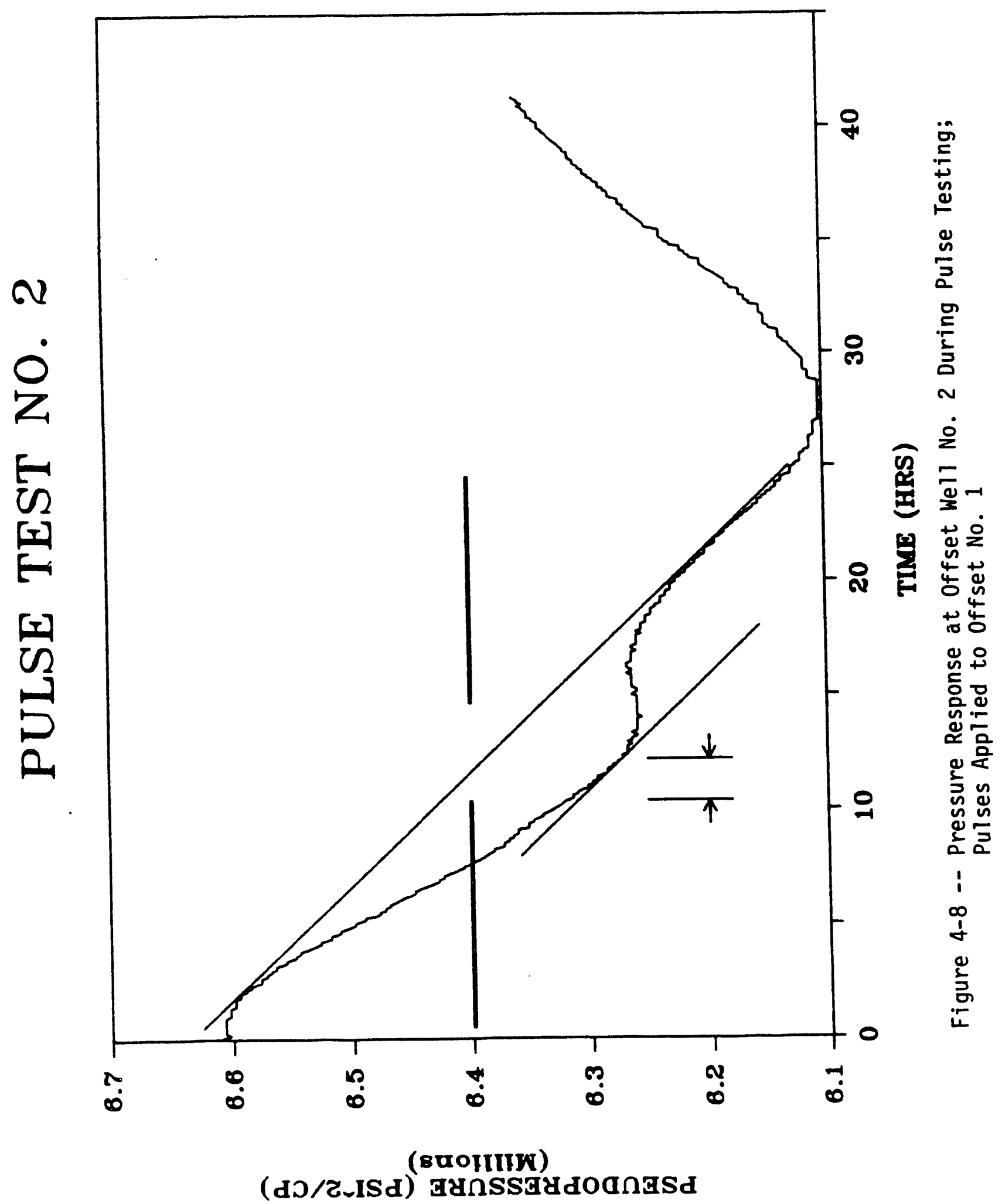

4-13 


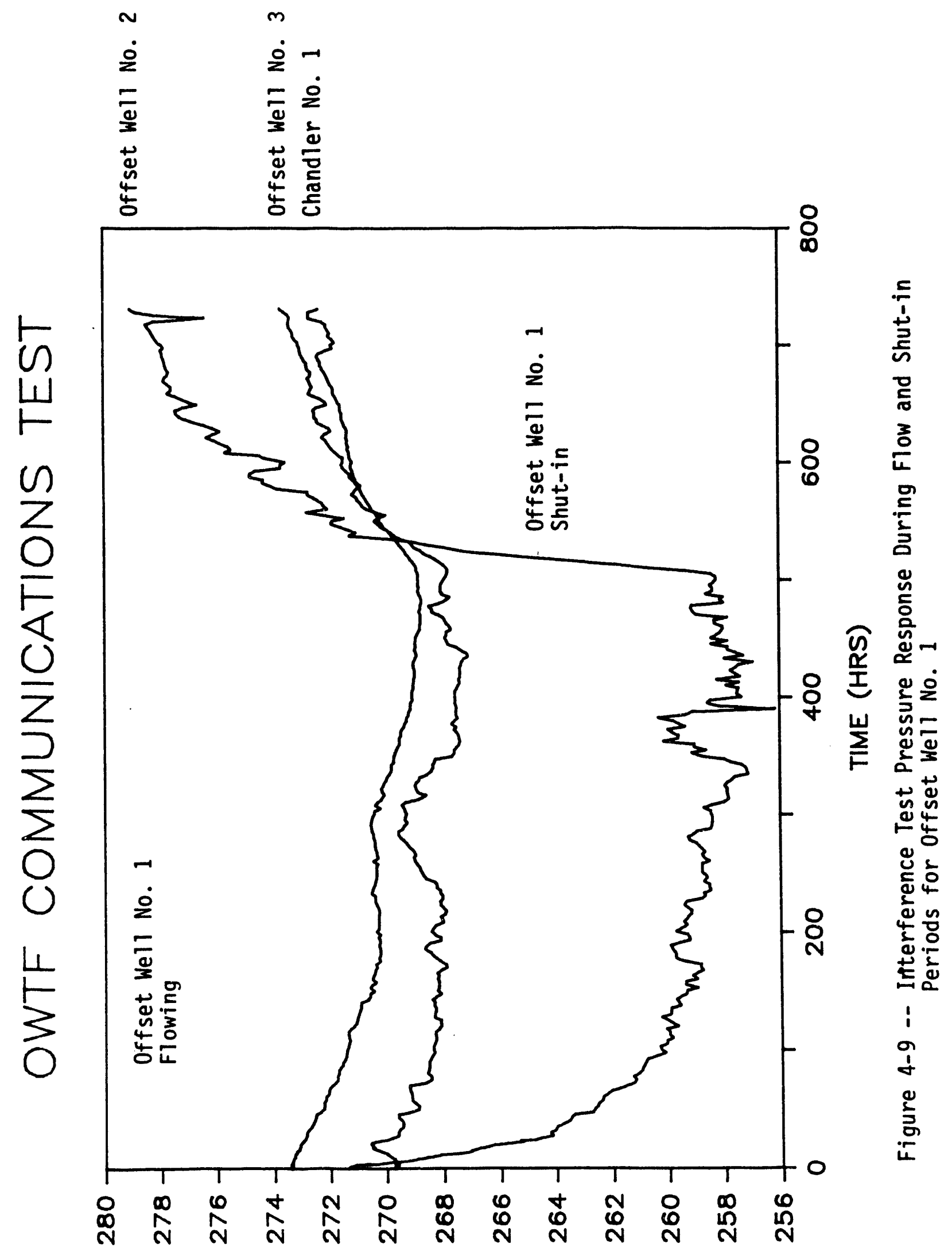

(כISd) $\exists y n S S \exists y d$ 
Because of the fact that this was to be a limited-entry treatment, it was necessary to run 4-1/2-inch casing through the Chattanooga Shale, cement it in place, and perforate. Casing that previously had been used in and retrieved from the Edna McClain \#22-18 Reservoir Properties well in Upshur County, West Virginia, was shipped to the site and run in offset Well No. 3 in preparation for stimulation. The casing was cemented in place and perforated with 10 shots opposite the Chattanooga Shale. Preparation of the well was completed on January 13, 1988, for the stimulation on the following day.

Another objective of this test was to determine the probable induced fracture orientation. Tiltmeters were installed approximately one month before the foam-frac treatment so that tiltmeter sites could be adequately conditioned, stabilized, and calibrated prior to measuring tilts at the earth's surface resulting from the stimulation. The tiltmeters were installed in a circular pattern around offset Well No. 3 at distances ranging from approximately 600 to 1000 feet. Six tiltmeters were installed on an irregular circle at the lesser of these two radii and another six at the greater of the two for a total of 12 tiltmeters. Figure 4-10 illustrates a typical tiltmeter installation. Figure 4-11 shows the locations of the tiltmeter sites relative to offset Wel1 No. 3.

In conjunction with the preparation of the sites for installation of the tiltmeters, earth resistivity profiles and gecchemical surveys were conducted to verify the existence of suspected fracture zones identified from SLAR (Side-looking Airborne Radar) and Landsat imagery maps and to locate other evidence of fractures at the surface of the site. Figure 4-12 shows the location of the survey lines and the SLAR/Landsat-detected fracture. zones with respect to the wells at the site.

Pressure-monitoring instruments were installed at each well and consisted of strain-gage transducers mounted at the wellhead and connected to the bottom of well by $0.094-i n c h$ I.D. stainless steel tubing strapped to the 2-3/8-inch tubing installed in each well. Pressures 


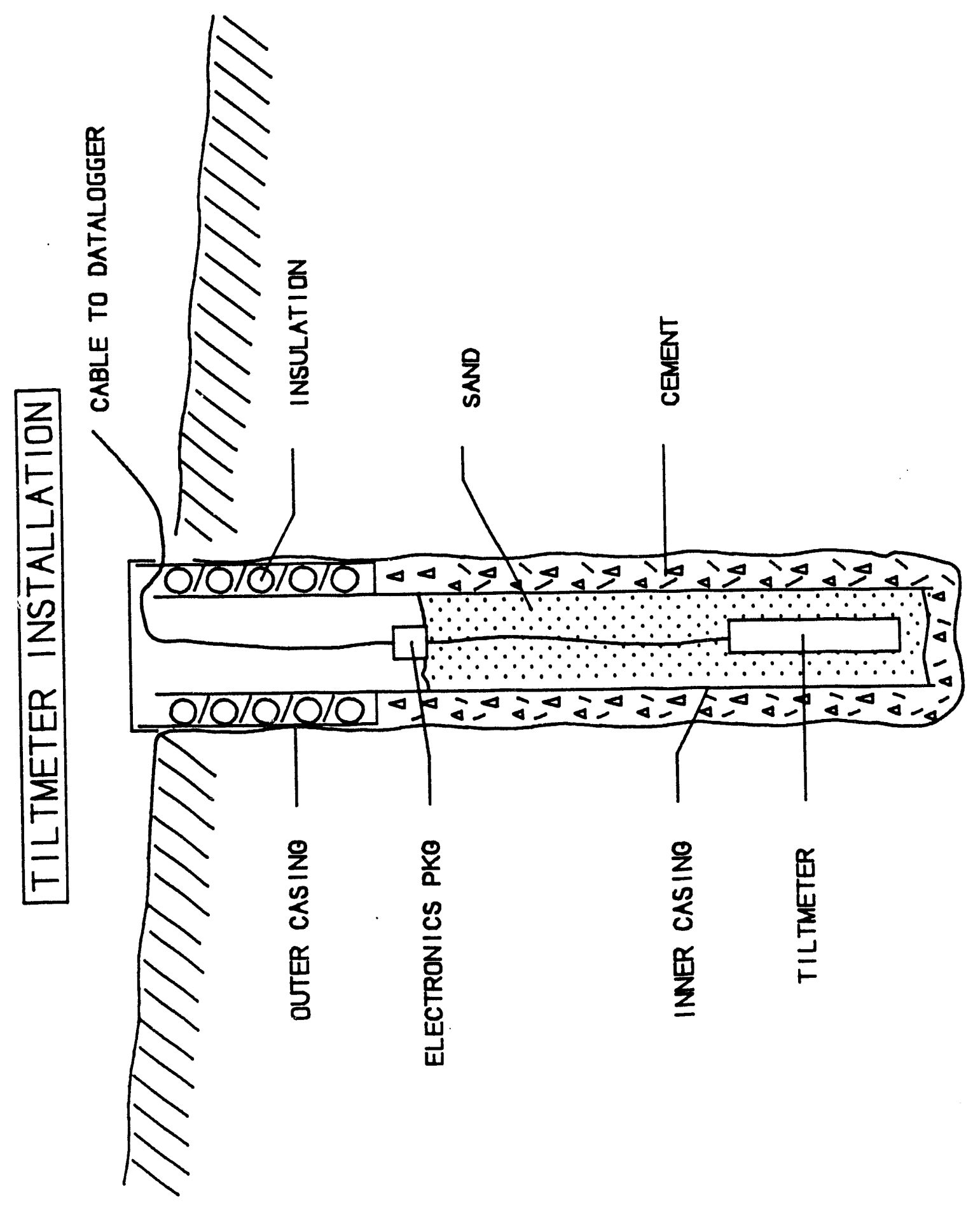

Figure 4-10 -- Typical Tiltmeter Installation 


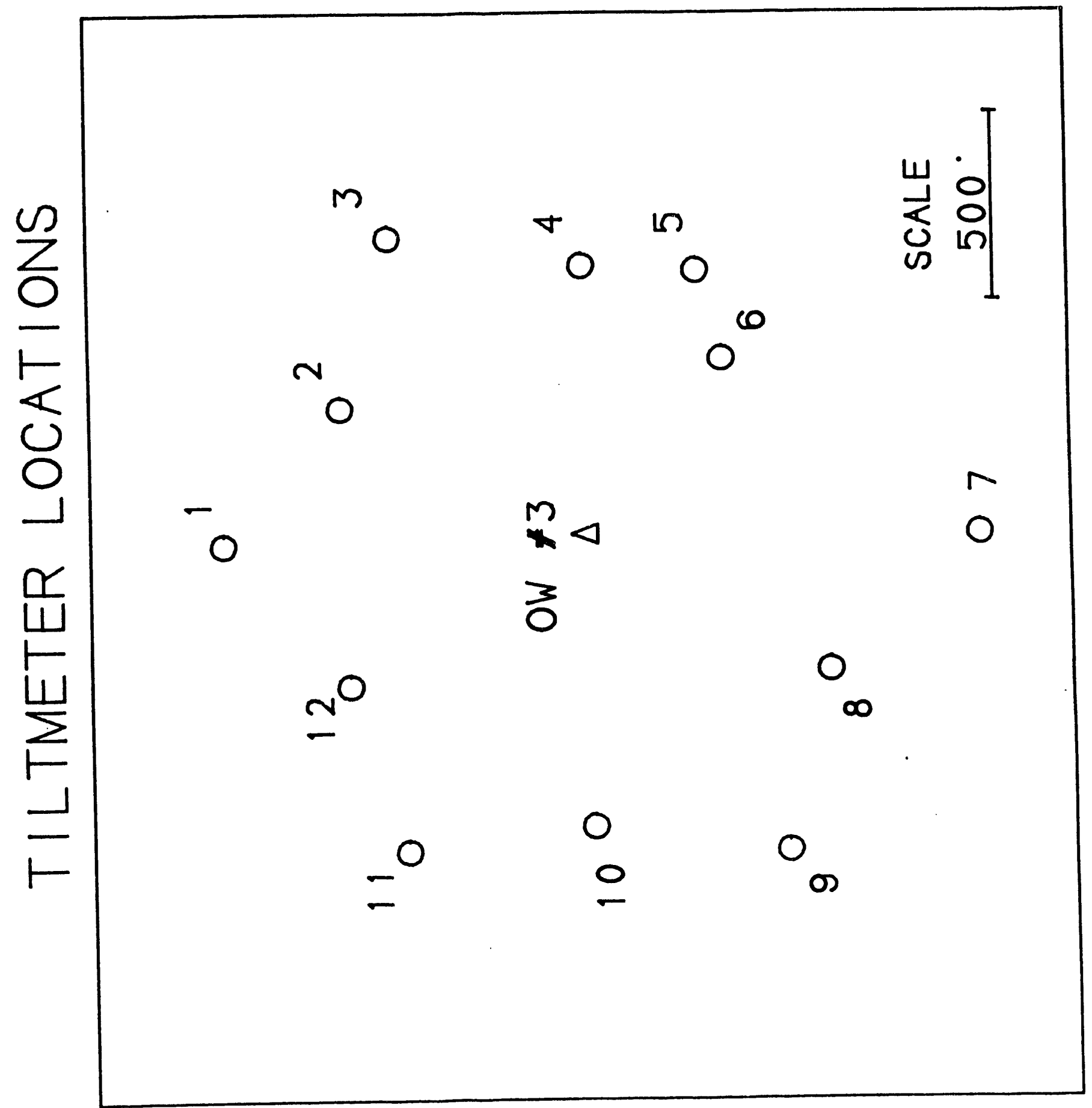

Figure 4-11 -- Location of Tiltmeter Sites 


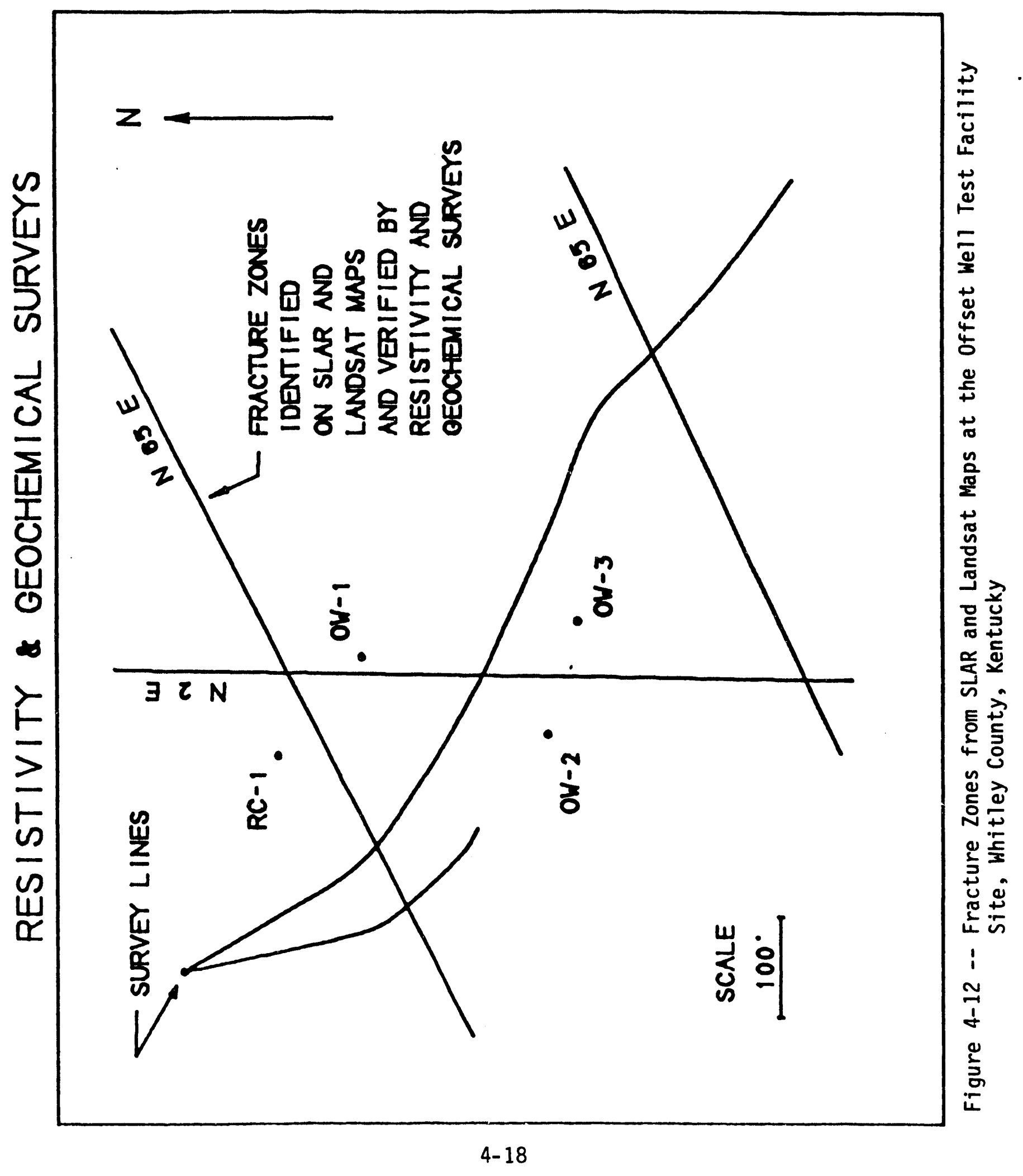


were transmitted to the surface pneumatically through the helium-filled, small-diameter tubing. A variation of this technique was used to monitor the pressure of Offset Well No. 3 while it was being stimulated. For this well, an expansion chamber was suspended on the small-diameter tubing inside 2-3/8-inch tubing for protection while frac fluids were injected down the annulus between the 2-3/8-inch tubing and the casing. Figures 4-13 and 4-14 illustrate the two methods for monitoring pressures during the stimulation.

On January 14, 1988, Offset Well No. 3 was stimulated with a limited-entry design single-stage foam-frac treatment. Approximately 70,000 gallons of sand-laden foam were injected at a nearly constant rate of $20 \mathrm{bbl} / \mathrm{min}$. Mechanical problems caused a shutdown after an hour and 15 minutes of injection, at which time the casing was flushed with nitrogen to prevent possible sanding off. Injection was restarted with no difficulty after having been shut down for 30 miriutes. Approximately 55,000 galions of fluid were injected during the first injection period with the remaining fluid being injected during the second injection period. Bottomhold and surface pressures in offset Well No. 3 are shown in Figure 4-15.

All tiltmeters were observed to respond to the fluid injection and all three monitoring wells recorded increases in pressure. No electronic or mechanical problems occurred to the tiltmeter equipment; however, four of the meters recorded responses that could not be readily reconciled with the rest of the tiltmeter data. These tiltmeters may have been affected by some other external influence or may have been recording the tilts caused by a more complex induced fracture system developed that could be explained by single- or dual-plane fracture models. The pressure monitoring equipment performed well during and following the stimulations; however, the cable to the transducer on offset Well No. 2 was severed by service trucks leaving the location after the job was completed. The transducer on offset Well No. 1 was inadvertently valved off after 17 hours of monitoring while pressure was still climbing at that location. Figures 4-16 and 4-17 show the pressure responses measured at the monitoring wells during and following the treatment. 


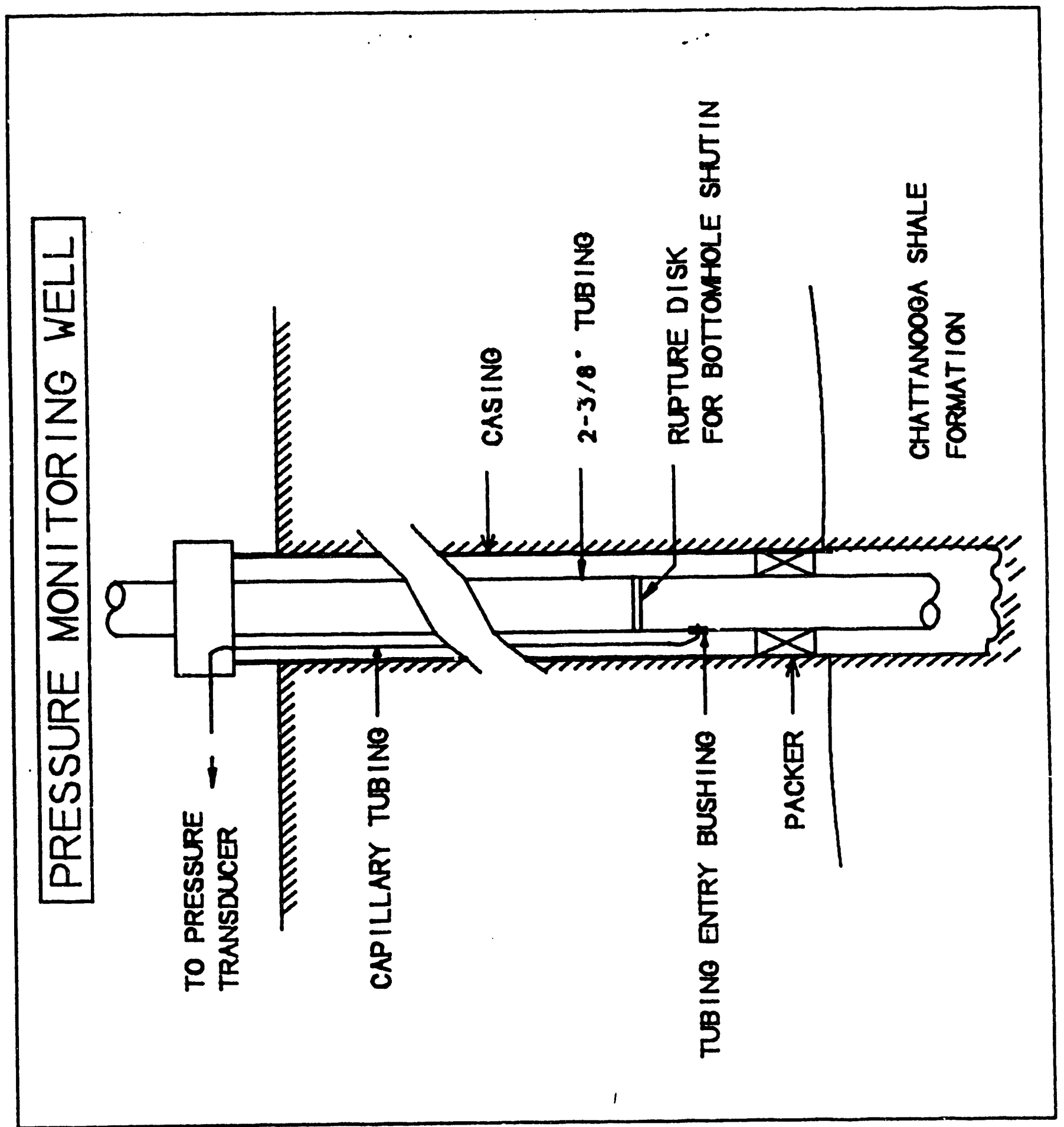

Figure 4-13. Schematic of Offset Pressure Monitoring Wells During Stimulation of Offset Well No. 3 


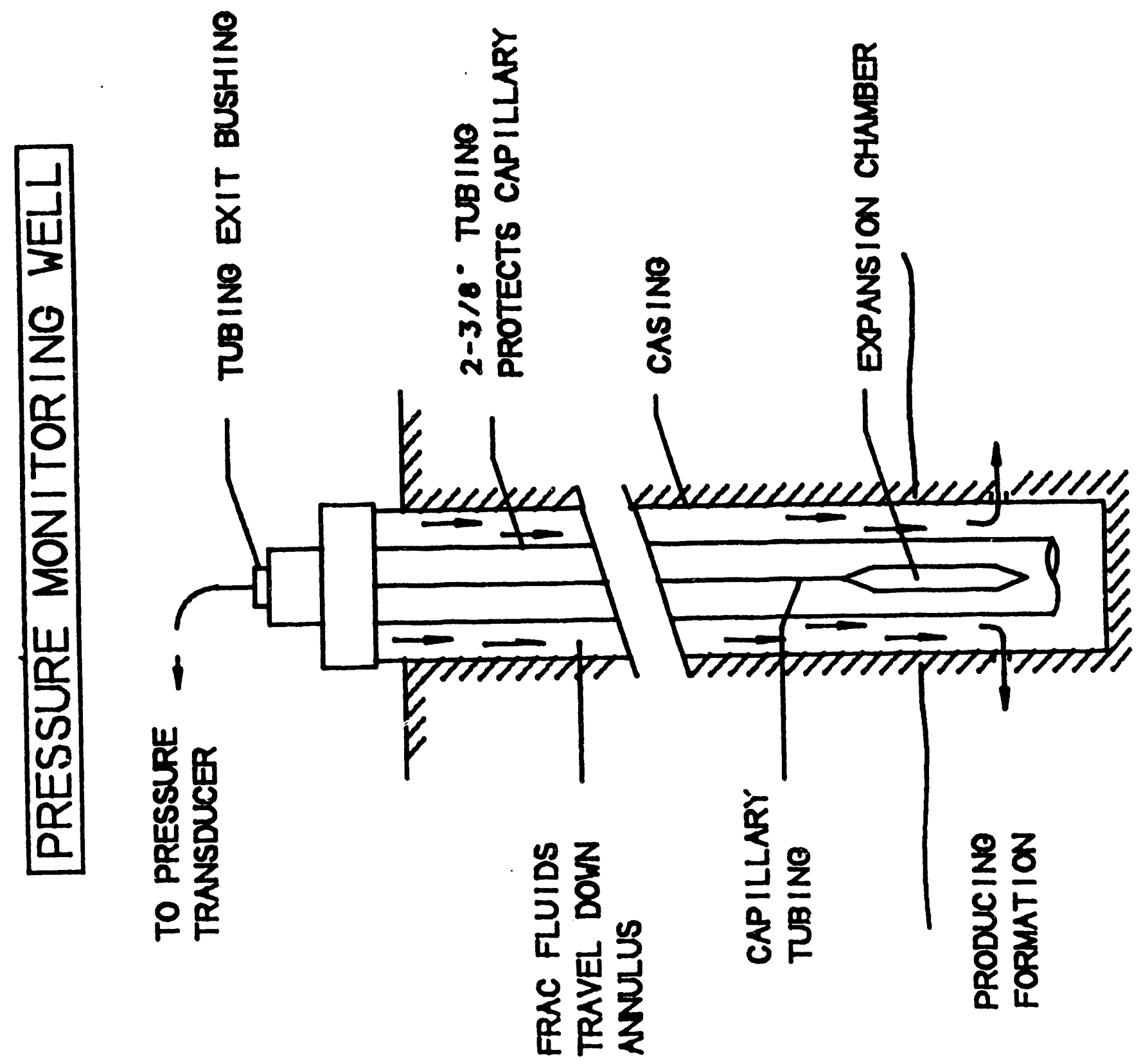

Figure 4-14. Schematic of Pressure Monitoring System for OWTF \#3 During its Foam-Frac Treatment 


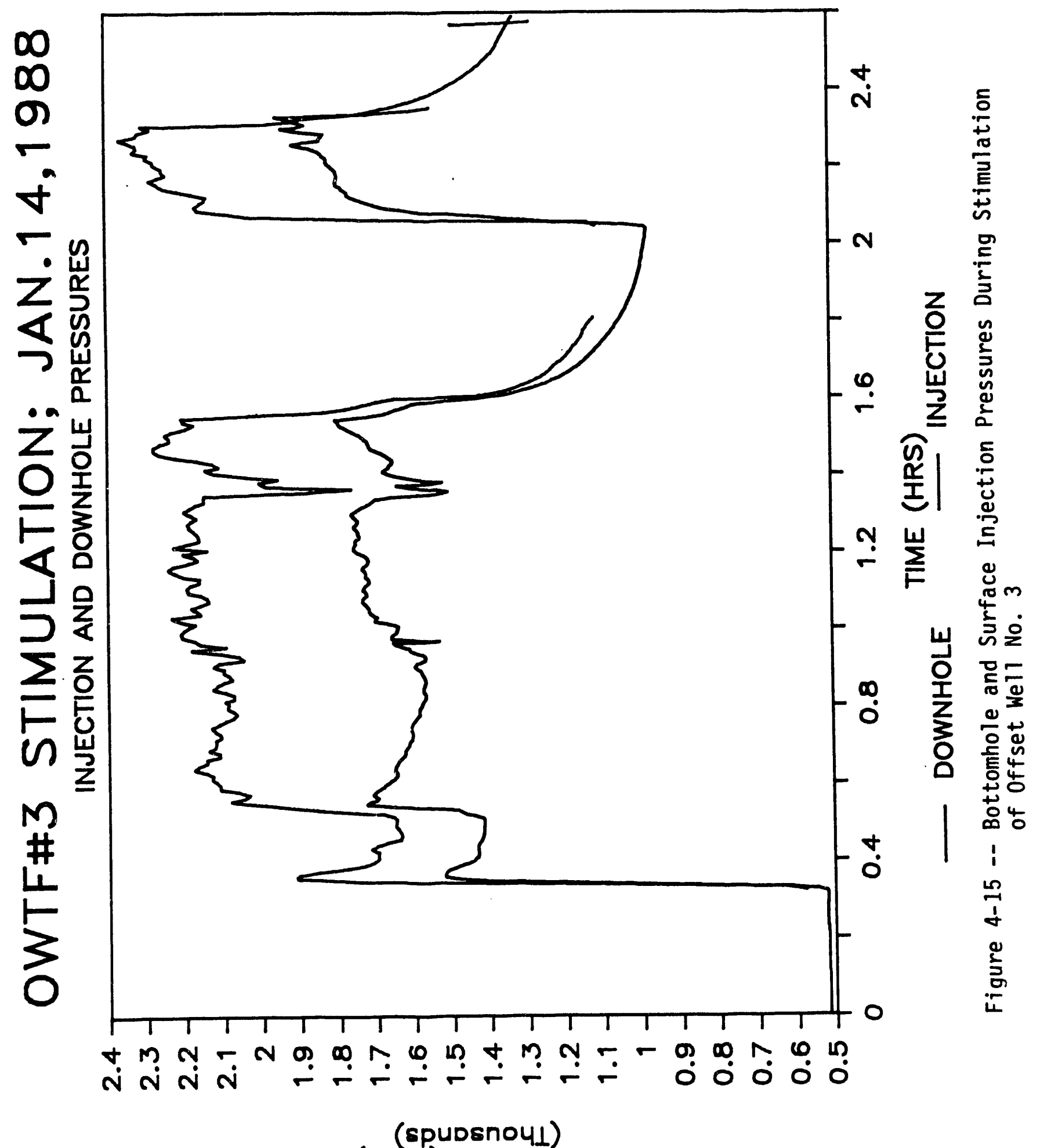

(गISd) उynsşadd 


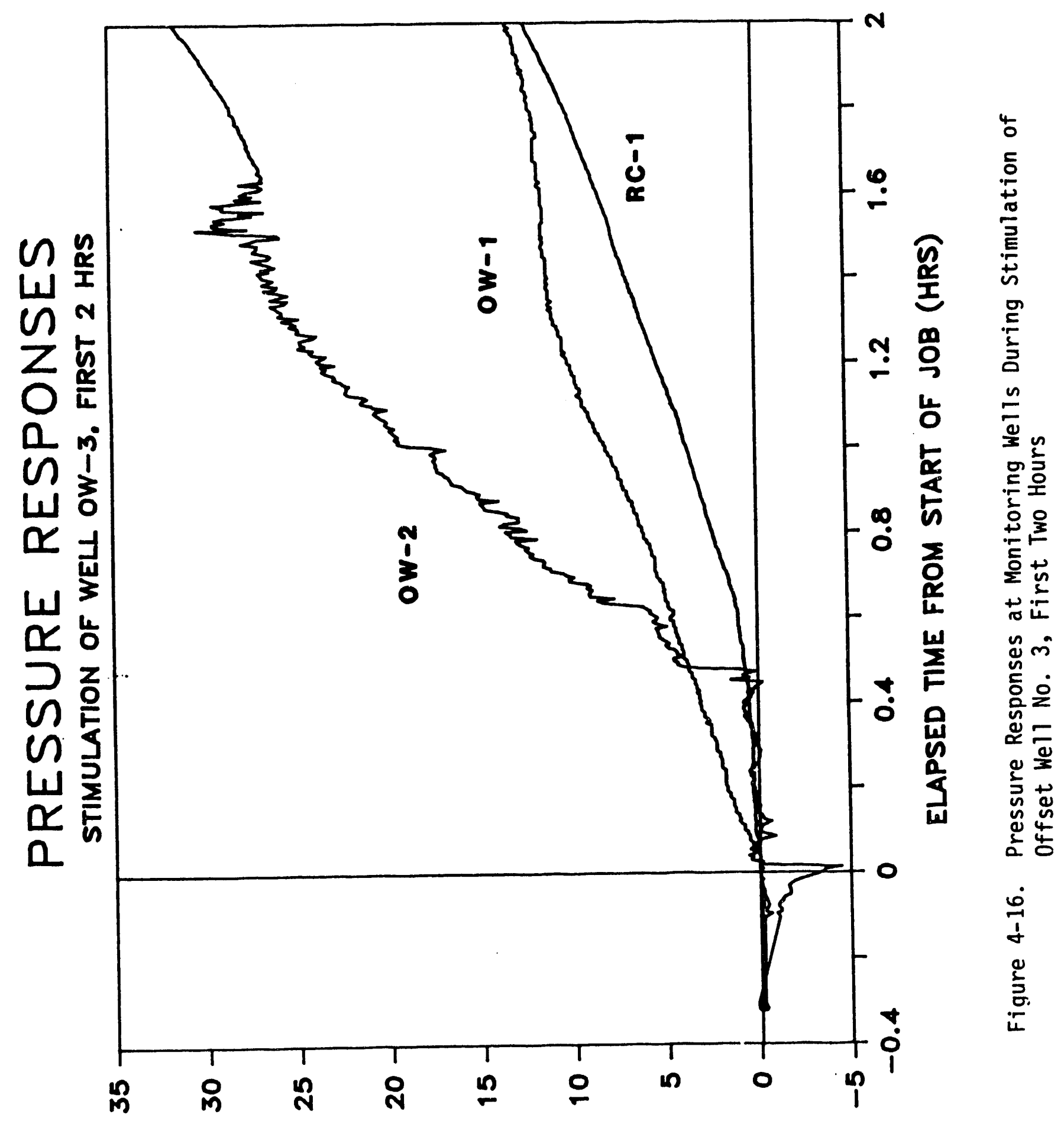

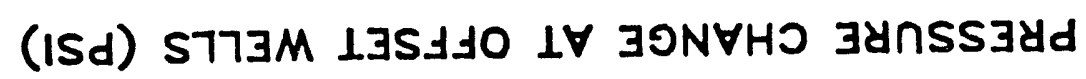




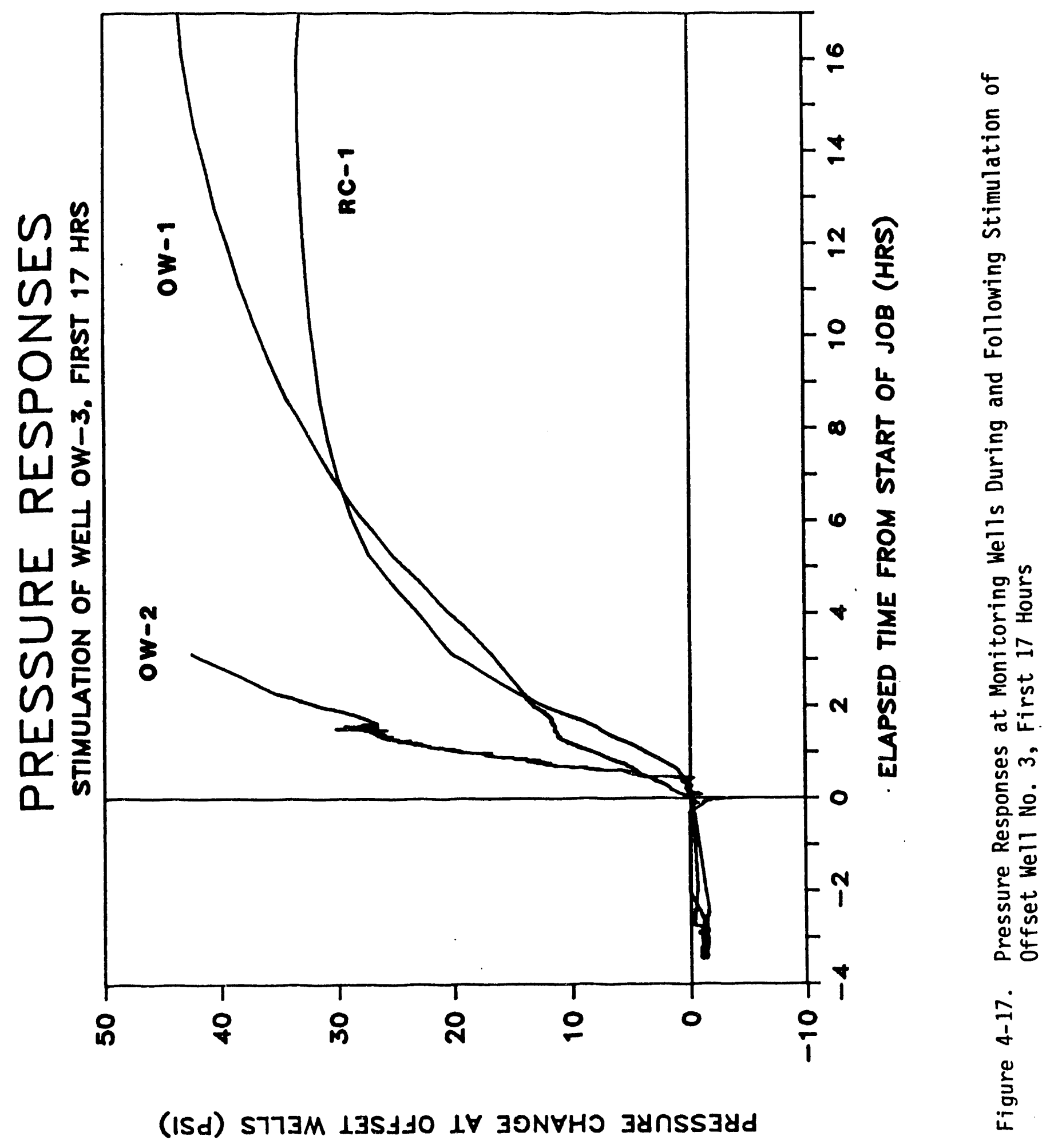


Following the stimulation of offset Well No. 3 , the well was allowed to clean up for approximately two weeks at which time the well had stabilized at approximately 60 mscfd but was not able to produce the water that had accumulated in the wellbore. A workover rig was moved onto the well and the tubing was checked for possible sandplugging, lowered to the depth just below the lowest perforation, and then swabbed to remove any remaining water. Following final clean-up, the well was shut-in and allowed to build up to a stabilized pressure prior to initiating post-frac testing. Post-frac testing consisted of a 4-week drawdown test beginning March 24, 1988, followed by a build-up test. Procedures for these tests were the same as for previous singlewell tests described in Section 3.0.

\subsubsection{Big Lime Recompletions}

During the series of tests conducted during early 1988, the reservoir pressure in the Chattanooga Shale at the Offset Well Test Facility site was observed to have declined significantly from its original value of approximately 330 psia, even though very little gas had been produced at the site from the Chattanooga. This fact, coupled with the fact that the Big Lime well (see Figure 4-2) had been placed on production in mid-December, raised the question of possible vertical interference between the Big Lime at a depth of approximately 1500 feet and the Chattanooga Shale at a depth of approximately 2000 feet. The intervening shale sequence was known to be somewhat naturally-fractured and gas-productive in some wells in the area. Therefore, the Big Lime was investigated to determine its reservoir characteristics, and to determine if it might be in communication with the Chattanooga.

Offset Wells No. 1 and 2 were the only wells other than the Big Lime producing well (Raymond Chandler No. 2) to have significant shows in the Big Lime, so these two wells were recompleted in the Big Lime interval for use in determining Big Lime reservoir characteristics. The wells were perforated through the 7-inch casing into the Big Lime at the point where these wells had indicated previous gas shows. Offset 
Well No. 2 was successfully recompleted by simply perforating the 7-inch casing; however, Offset Well No. 1 had to have a small amount of acid displaced through the perforations to establish a connection with the Big Lime reservoir. After acid displacement in offset Well No. 1 , the gas flow from the Big Lime was too strong to allow installation of dualcompletion equipment without incurring excessive cost and/or excessive risk; therefore, a bridge plug was set in the 7-inch casing below the Big Lime perforations to isolate the Big Lime from the formations below. Offset Well No. 2 was dual-completed in the Big Lime and the Chattanooga by running a dual-packer assembly on 2-3/8-inch tubing, with the lower packer set just above the Chattanooga and the upper packer set in the 7-inch casing just below the Big Lime. Figures 4-18 and 4-19 show the wellbore equipment configurations for testing the Big Lime.

Investigations of possible Big Lime production influence on the Chattanooga Shale included examination of Big Lime production from the Raymond Chandler No. 2 well, analysis of the production history including periods of relative constant production rates and occasional shut-in periods of up to 10 days, and pulse-testing between the Chandler No. 2 and the two Offset Wells No. 1 and 2. The pressure history for the Chandler No. 2 well is shown in Figure 4-20.

The pulse test on the Big Lime was conducted on July 11, 1988, by generating four pulses alternating flow rates on the Big Lime well between $250 \mathrm{mscfd}$ and $60 \mathrm{mscfd}$ for periods of 35 and 15 minutes, respectively, to achieve the optimum 0.7 and 0.3 to 1.0 pulse times to total pulse period ratios. The pulse test pressures at all three wells are shown in Figure 4-21. As can be seen from the pressures in Figure 4-21, the pressure wave was transmitted very rapidly from well to well, indicative of a fractured reservoir. in the Big Lime. 


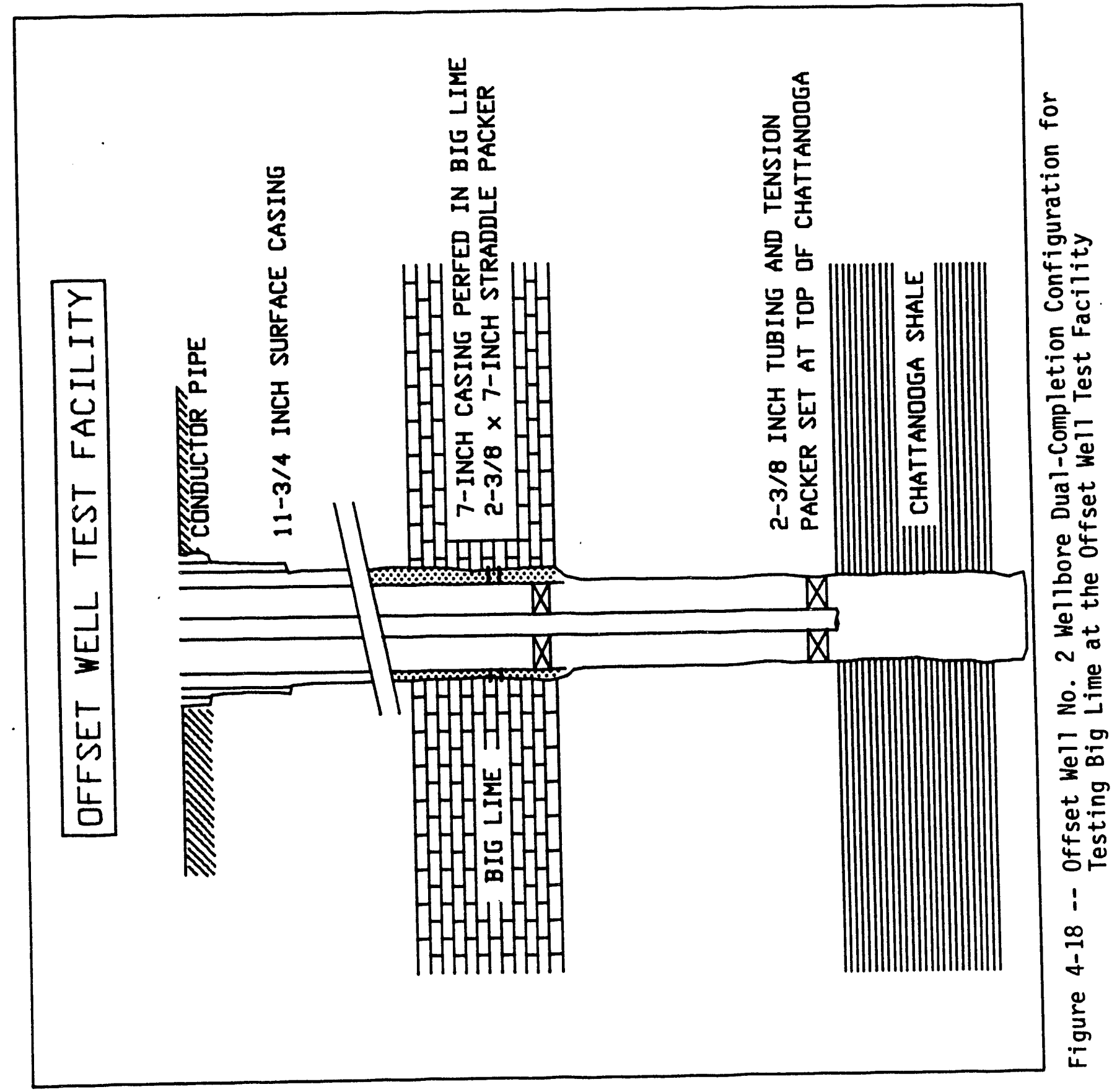




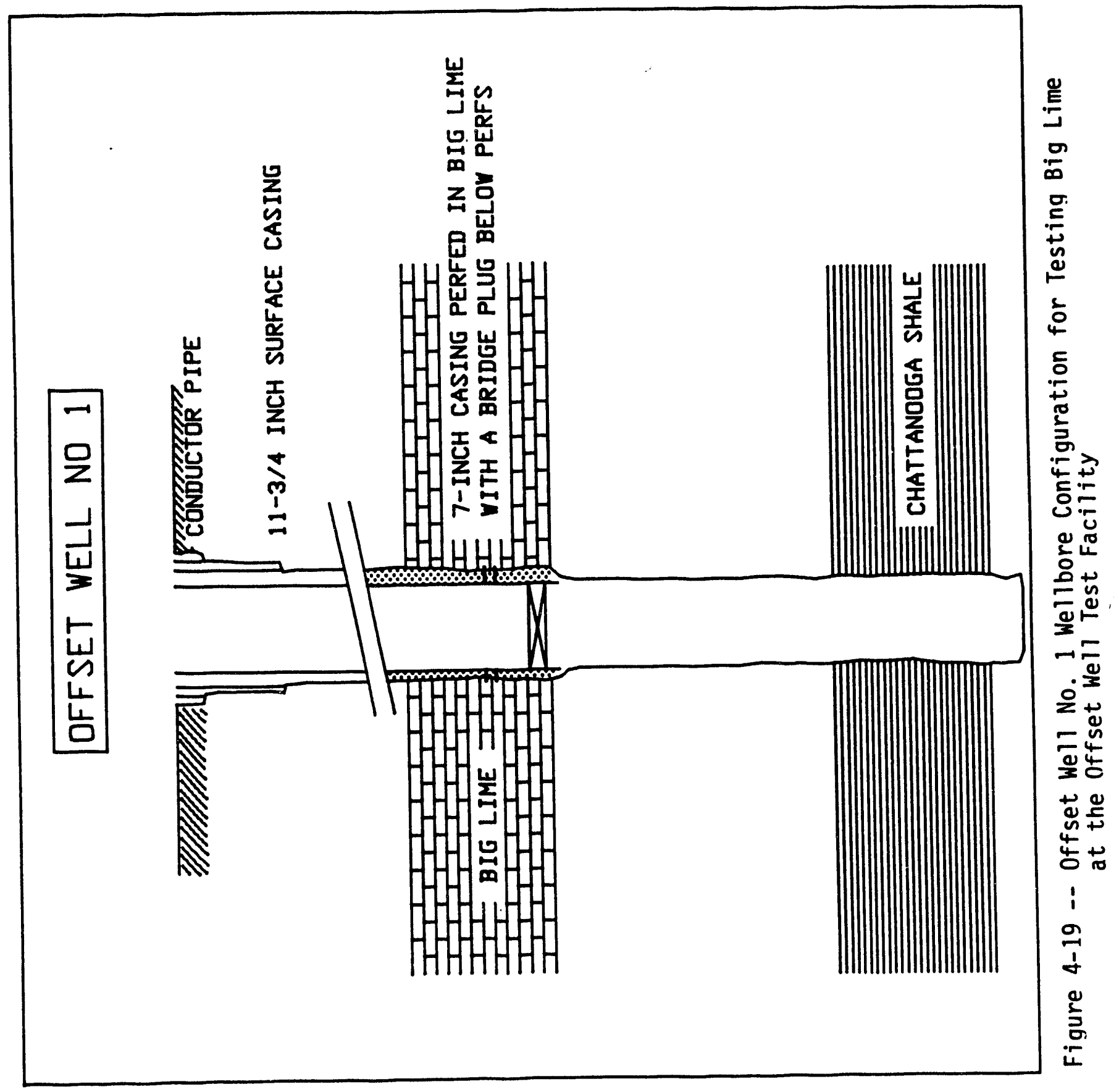




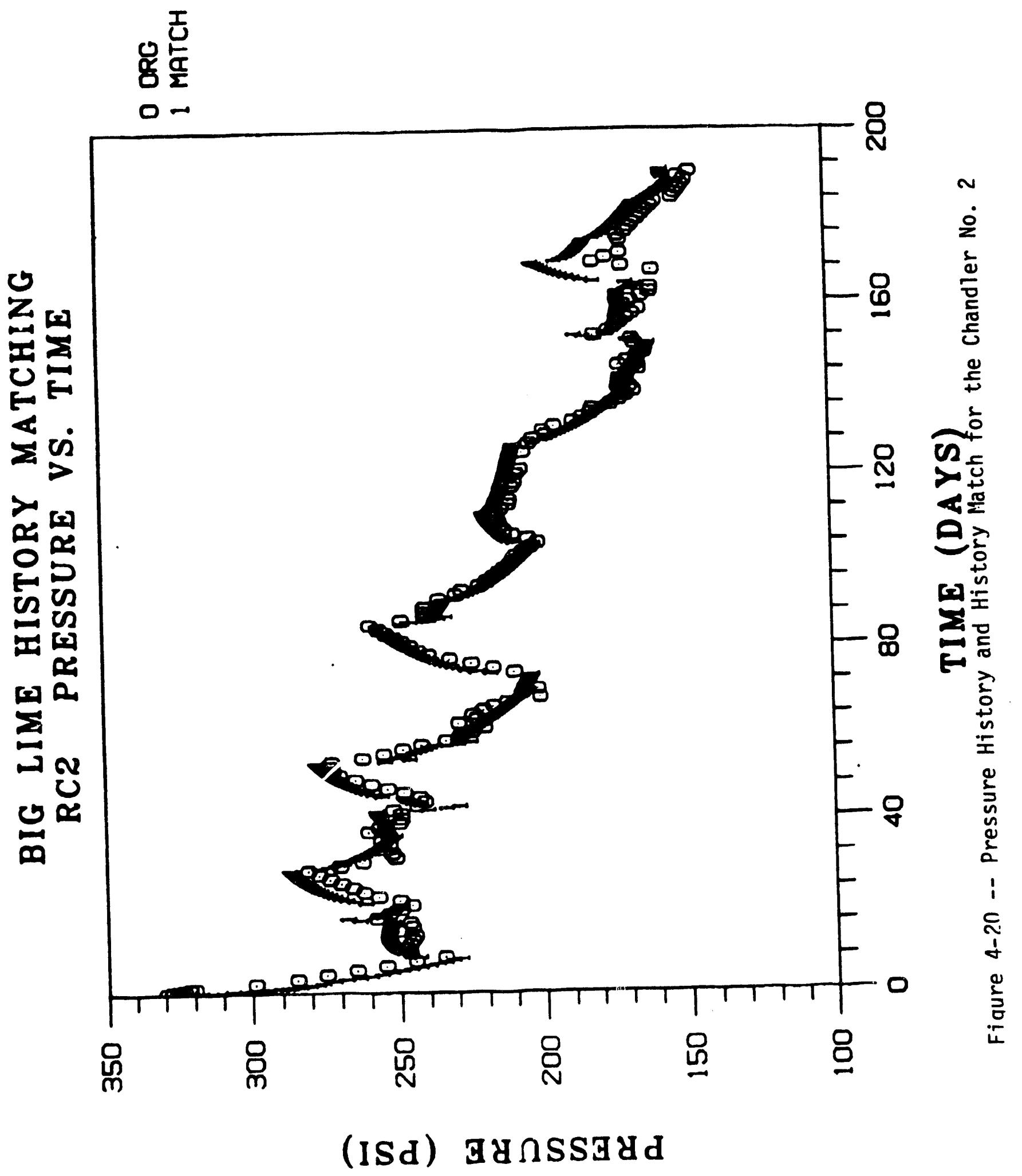




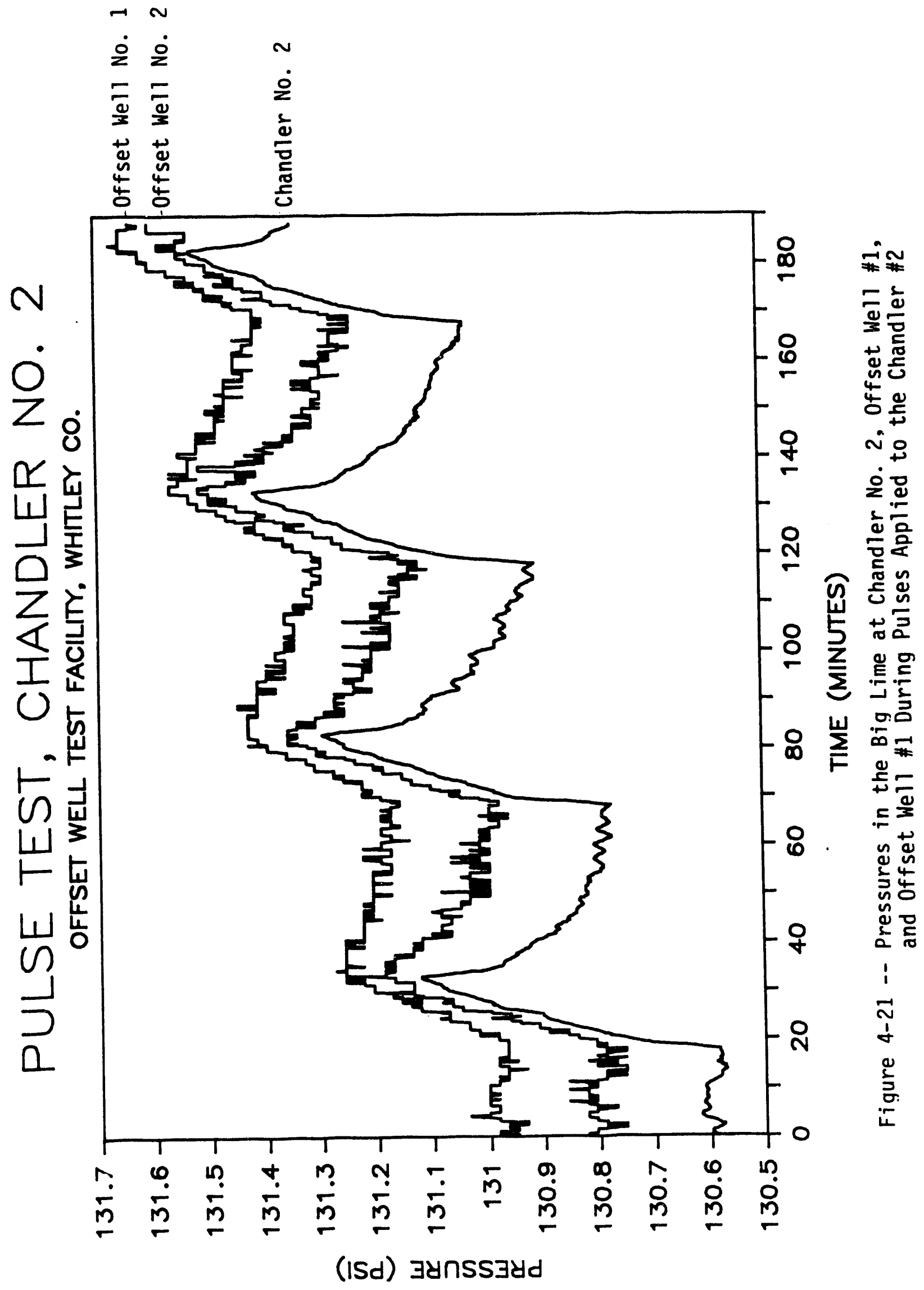




\subsection{RESULTS AND CONCLUSIONS}

\subsection{Core Analyses}

Core analyses consisted of both basic and special core analyses procedures. The results of these tests are summarized in Tables 5-1 through 5-5. Detailed basic core analysis results are shown in Table 5-1 for each sample tested and for each well cored. Table 5-2 shows a summary of the core-fracture data for each well. Table 5-3 summarizes the results of gas desorption studies including minimum, maximum, and average gas recovery on a volume-of-gas per volume-of-core sample basis. Table 5-4 presents averaged data for vitrinite reflectance, thermal alteration index, water saturation, porosity, and gas permeability (under confining pressures of approximately one psi per foot of depth). Table 5-5 summarizes the results of rock mechanics testing to determine probable orientations of fractures induced in the target shale formation for each of the cored wells.

\subsection{Well Test Analysis of Reservoir Properties Wells}

Well tests were conducted on each of the Reservoir Properties Wells-of-Opportunity as described in section 3.0. Where possible, both gas and water samples were taken from the wells and analyzed. The results of these tests are summarized in Tables 5-6 through 5-8. Table 5-6 shows permeability and stress ratio data for each of the wells tested. Table 5-7 shows the results of chromatographic analyses of natural gas samples taken from each of the wells. Brine samples were acquired and analyzed for the Stevens, McClain, and Bolt wells. These results are shown in Table 5-8. 
TABLE 5-1

BASIC CORE ANALYSIS SUMMARY

\begin{tabular}{|c|c|c|c|c|c|c|c|}
\hline WELL & \multirow[t]{2}{*}{$\begin{array}{l}\text { SAMPLE } \\
\text { NUMBER } \\
\end{array}$} & \multirow[t]{2}{*}{$\begin{array}{l}\text { DEPTH } \\
\text { (feet) } \\
\end{array}$} & \multirow[t]{2}{*}{$\begin{array}{c}\text { WATER } \\
\text { SATURATION } \\
\begin{array}{c}(\%) \\
\end{array}\end{array}$} & \multirow[t]{2}{*}{$\begin{array}{c}\text { AMBIENT } \\
\text { POROSITY } \\
(\%) \\
\end{array}$} & GAS & \multicolumn{2}{|c|}{$\begin{array}{l}\text { PERMEABILITY ( } \mathrm{dd}) \\
\text { Pnet (psi) }\end{array}$} \\
\hline & & & & & $\underline{1616}$ & 3232 & 6464 \\
\hline L.B. SOUTHWICK \#1 & $\begin{array}{l}1 \\
2 \\
3 \\
4 \\
5 \\
6\end{array}$ & $\begin{array}{l}3204.1 \\
3215.2 \\
3226.3 \\
3236.7 \\
3247.9 \\
3260.0\end{array}$ & $\begin{array}{r}100 \\
84 \\
91 \\
99 \\
90 \\
76\end{array}$ & $\begin{array}{l}2.4 \\
3.0 \\
2.7 \\
1.6 \\
1.3 \\
1.9\end{array}$ & $\begin{array}{r}5.69 \\
11.73 \\
18.14 \\
4.10 \\
0.12 \\
<0.01\end{array}$ & $\begin{array}{r}1.87 \\
4.87 \\
7.24 \\
0.91 \\
0.01 \\
<0.01\end{array}$ & $\begin{array}{l}0.16 \\
0.29 \\
0.63 \\
<0.01 \\
<0.01 \\
<0.01\end{array}$ \\
\hline & & & & & 1694 & 3388 & 6786 \\
\hline P.D. McCARTNEY \# 1 & $\begin{array}{l}1 \\
2 \\
3 \\
4 \\
5 \\
6\end{array}$ & $\begin{array}{l}3363.1 \\
3373.6 \\
3383.7 \\
3392.6 \\
3403.8 \\
3410.7\end{array}$ & $\begin{array}{l}46 \\
47 \\
49 \\
70 \\
66 \\
\text { ND }\end{array}$ & $\begin{array}{l}6.8 \\
4.5 \\
4.5 \\
4.2 \\
3.1 \\
2.3\end{array}$ & $\begin{array}{r}50.66 \\
0.71 \\
<0.01 \\
0.18 \\
0.20 \\
0.29\end{array}$ & $\begin{array}{r}10.32 \\
0.20 \\
<0.01 \\
0.03 \\
0.04 \\
0.08\end{array}$ & $\begin{array}{r}0.50 \\
0.01 \\
<0.01 \\
<0.01 \\
<0.01 \\
<0.01\end{array}$ \\
\hline & & & & & 2645 & 5290 & 10580 \\
\hline A.B. WILSON \#19 & $\begin{array}{l}1 \\
2 \\
3 \\
4 \\
5 \\
6\end{array}$ & $\begin{array}{l}5263.8 \\
5275.6 \\
5286.3 \\
5298.5 \\
5301.5 \\
5318.4\end{array}$ & $\begin{array}{l}82 \\
\text { ND } \\
\text { ND } \\
49 \\
\text { ND } \\
83\end{array}$ & $\begin{array}{r}3.2 \\
\text { ND } \\
\text { ND } \\
5.1 \\
\text { ND } \\
2.6\end{array}$ & $\begin{array}{r}0.05 \\
\text { ND } \\
\text { ND } \\
10.34 \\
\text { ND } \\
<0.01\end{array}$ & $\begin{array}{r}<0.01 \\
\text { ND } \\
\text { ND } \\
2.56 \\
\text { ND } \\
<0.01\end{array}$ & $\begin{array}{r}<0.01 \\
\text { ND } \\
\text { ND } \\
0.20 \\
\text { ND } \\
<0.01\end{array}$ \\
\hline & & & & & 724 & 1447 & 2893 \\
\hline STEVENS \#1-12 & $\begin{array}{l}1 \\
2 \\
3 \\
4 \\
5\end{array}$ & $\begin{array}{l}1424.5 \\
1434.0 \\
1445.6 \\
1458.5 \\
1470.5\end{array}$ & $\begin{array}{l}49 \\
54 \\
51 \\
81 \\
62\end{array}$ & $\begin{array}{l}5.3 \\
5.7 \\
5.6 \\
3.5 \\
4.7\end{array}$ & $\begin{array}{l}<0.01 \\
<0.01 \\
<0.01 \\
<0.01 \\
<0.01\end{array}$ & $\begin{array}{l}<0.01 \\
<0.01 \\
<0.01 \\
<0.01 \\
<0.01\end{array}$ & $\begin{array}{l}<0.01 \\
<0.01 \\
<0.01 \\
<0.01 \\
<0.01\end{array}$ \\
\hline & & & & & 970 & 1940 & 3880 \\
\hline R. CHANDLER \# 1 & $\begin{array}{l}1 \\
2 \\
3 \\
4 \\
5 \\
6 \\
7\end{array}$ & $\begin{array}{l}1918.2 \\
1920.4 \\
1945.8 \\
1958.0 \\
1974.9 \\
1988.9 \\
1999.9\end{array}$ & $\begin{array}{r}88 \\
71 \\
100 \\
100 \\
100 \\
93 \\
56\end{array}$ & $\begin{array}{l}2.75 \\
2.02 \\
1.34 \\
1.34 \\
1.36 \\
1.97 \\
1.34\end{array}$ & $\begin{array}{l}3.12 \\
<0.01 \\
<0.01 \\
<0.01 \\
<0.01 \\
<0.01 \\
<0.01\end{array}$ & $\begin{array}{l}0.60 \\
<0.01 \\
<0.01 \\
<0.01 \\
<0.01 \\
<0.01 \\
<0.01\end{array}$ & $\begin{array}{l}<0.01 \\
<0.01 \\
<0.01 \\
<0.01 \\
<0.01 \\
<0.01 \\
<0.01\end{array}$ \\
\hline
\end{tabular}


TABLE 5-1

BASIC CORE ANALYSIS SUMMARY (continued)

\begin{tabular}{|c|c|c|c|c|c|c|c|}
\hline \multirow[t]{2}{*}{ WELL } & \multirow[t]{2}{*}{$\begin{array}{l}\text { SAMPLE } \\
\text { NUMBER } \\
\end{array}$} & \multirow[t]{2}{*}{$\begin{array}{r}\text { DEPTH } \\
\text { (feet) } \\
\end{array}$} & \multirow[t]{2}{*}{$\begin{array}{c}\text { WATER } \\
\text { SATURATION } \\
(\%) \\
\end{array}$} & \multirow[t]{2}{*}{$\begin{array}{c}\text { AMBIENT } \\
\text { POROSITY } \\
(\%) \\
\end{array}$} & \multicolumn{3}{|c|}{$\begin{array}{c}\text { GAS PERMEABILITY ( } \mu d) \\
\text { Pnet (psi) }\end{array}$} \\
\hline & & & & & 754 & 2973 & 7395 \\
\hline \multirow[t]{2}{*}{ MEADOWLARK \# 1} & $\begin{array}{l}1 \\
2 \\
3 \\
4 \\
5 \\
6\end{array}$ & $\begin{array}{l}4397.1 \\
4407.2 \\
4420.1 \\
4428.8 \\
4440.8 \\
4448.4\end{array}$ & $\begin{array}{r}\text { ND } \\
93 \\
100 \\
100 \\
81 \\
76\end{array}$ & $\begin{array}{l}3.3 \\
2.1 \\
1.4 \\
0.9 \\
1.9 \\
3.2\end{array}$ & $\begin{array}{r}8.23 \\
9.43 \\
28.30 \\
4.00 \\
2.00 \\
\text { ND }\end{array}$ & $\begin{array}{r}3.22 \\
1.23 \\
2.54 \\
0.37 \\
1.54 \\
257.60\end{array}$ & $\begin{array}{r}0.32 \\
<0.01 \\
0.07 \\
<0.01 \\
<0.01 \\
42.70\end{array}$ \\
\hline & & & & & 3353 & 7105 & 11600 \\
\hline E. MCCLAIN \#22-18 & $\begin{array}{l}1 \\
2 \\
3 \\
4\end{array}$ & $\begin{array}{l}7137.1 \\
7141.7 \\
7147.7 \\
7153.4\end{array}$ & $\begin{array}{l}54 \\
70 \\
51 \\
53\end{array}$ & $\begin{array}{r}11.7 \\
9.4 \\
8.6 \\
13.1\end{array}$ & $\begin{array}{c}\ldots \text { POOR } \\
<0.01 \\
0.197 \\
4.97 *\end{array}$ & $\begin{array}{c}\text { SAMPLE } \\
<0.01 \\
0.145 \\
<0.01\end{array}$ & $\begin{array}{c}\text { QUALITY } \\
<0.01 \\
5.13^{\star} \\
<0.01\end{array}$ \\
\hline * Probable fract & eith & in $s$ & or in $\mathrm{e}$ & $y$ coat & & & \\
\hline
\end{tabular}




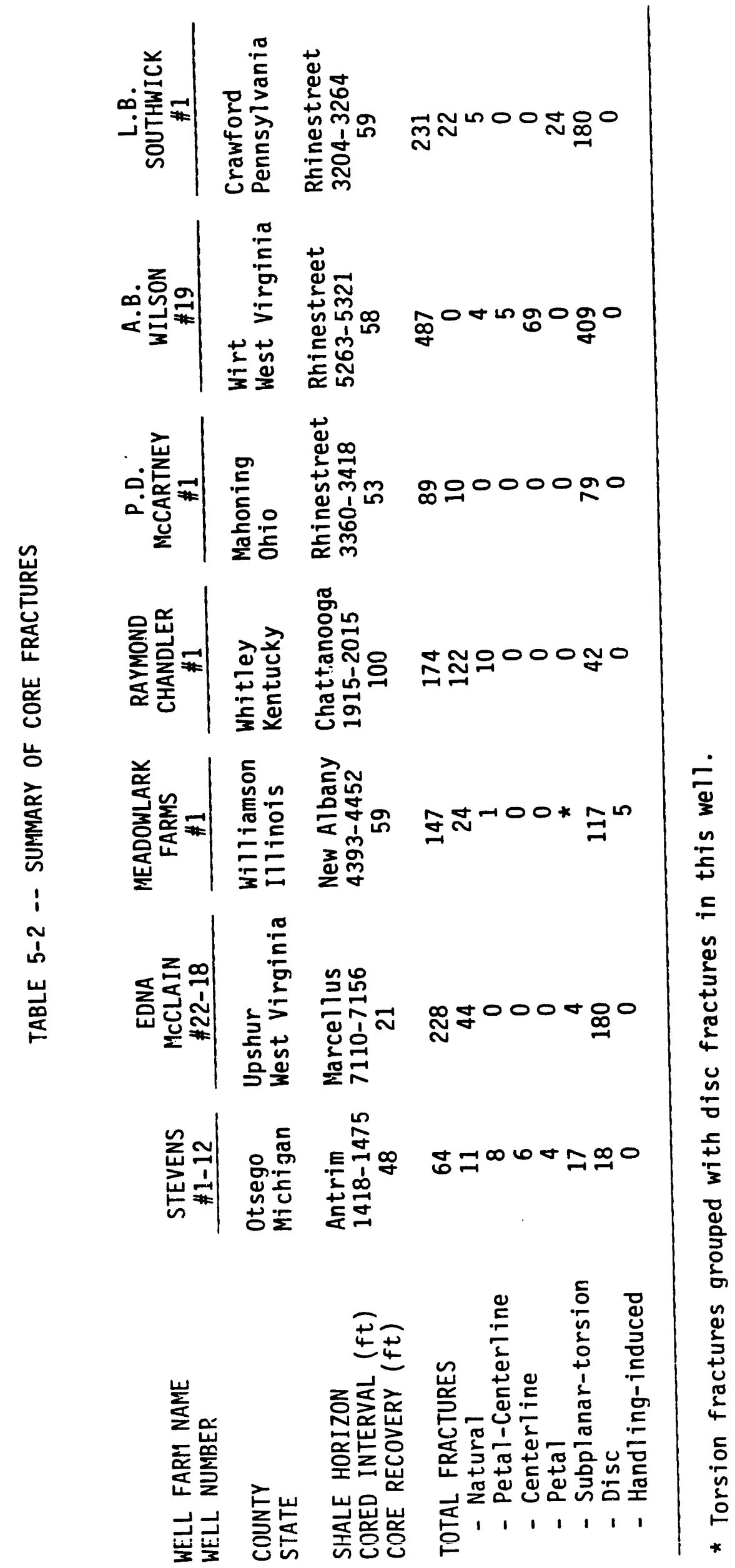




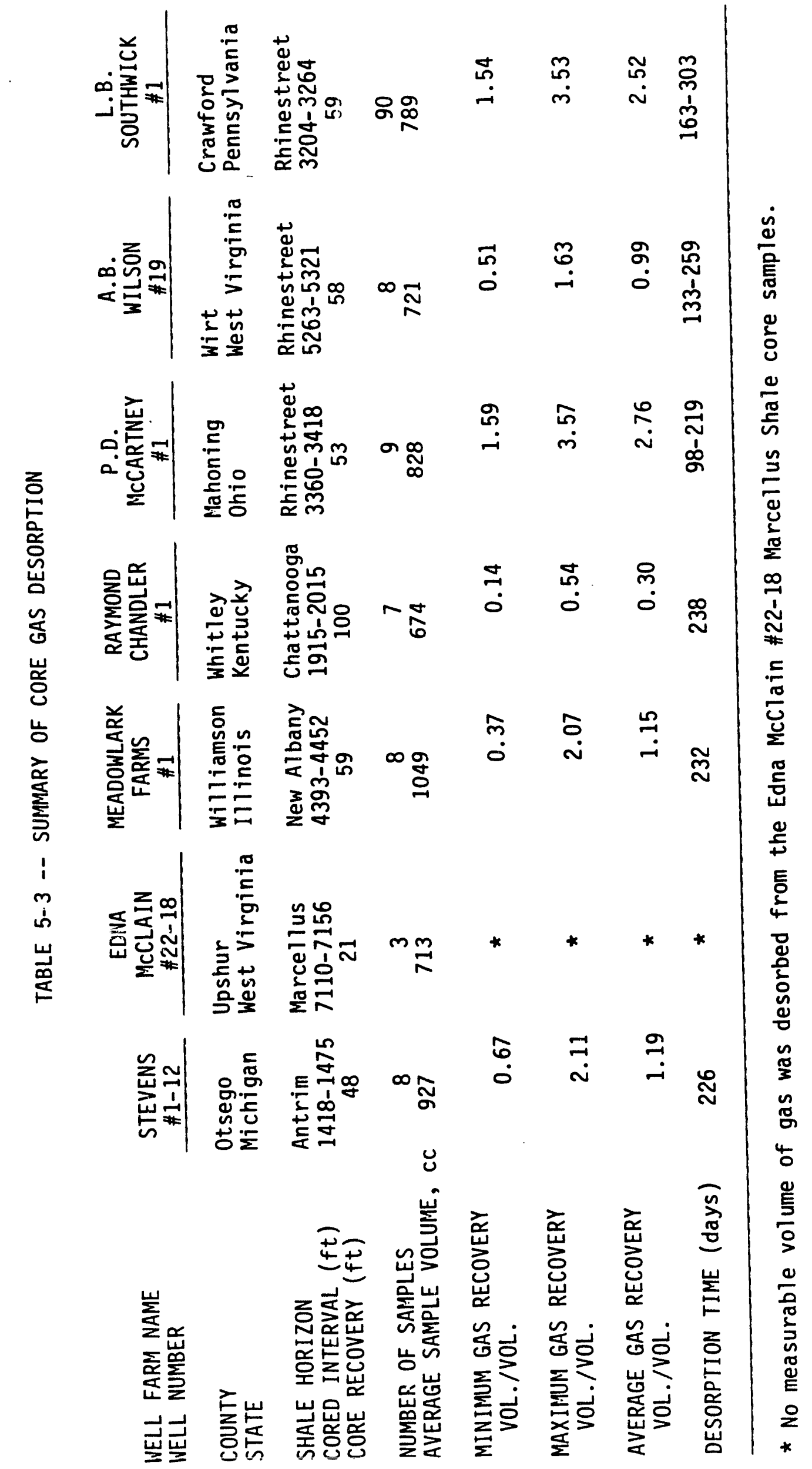




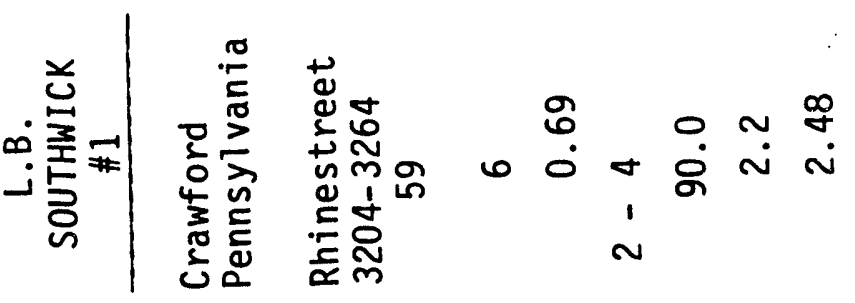

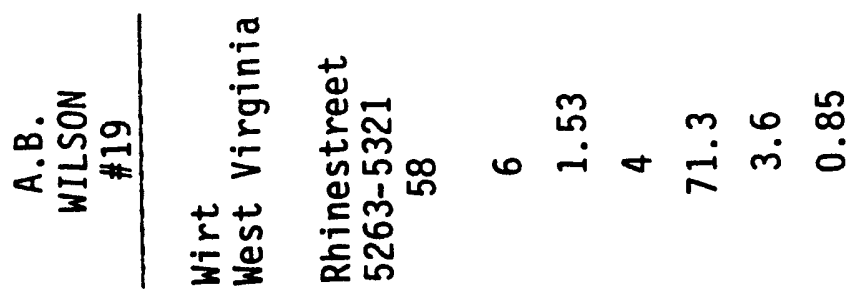

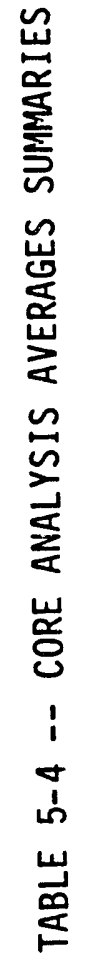

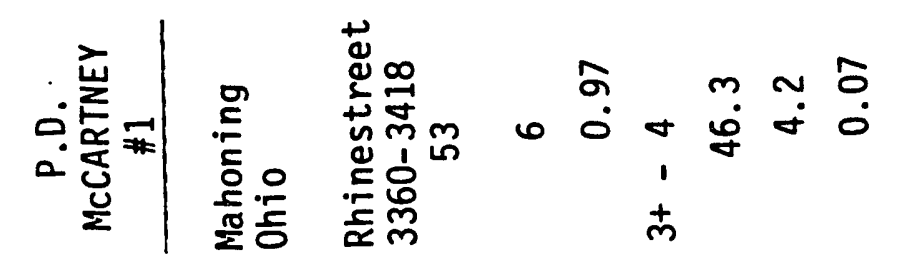

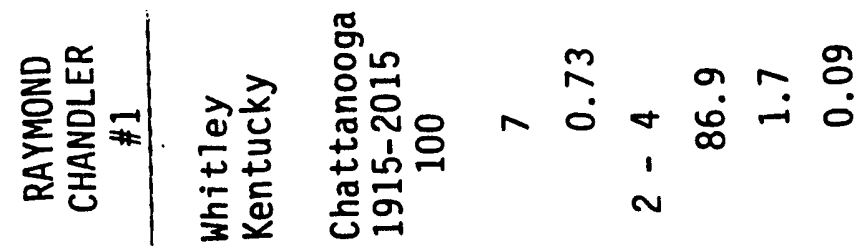

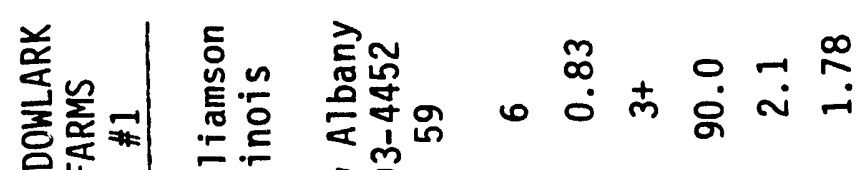

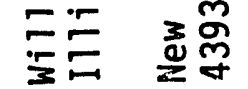

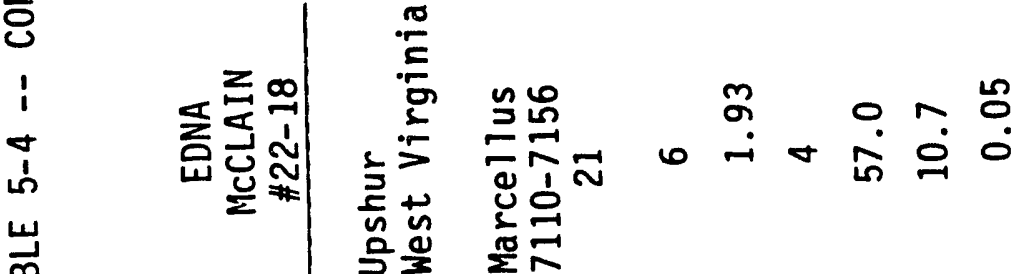

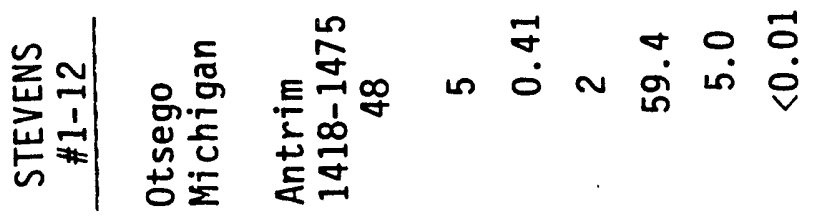

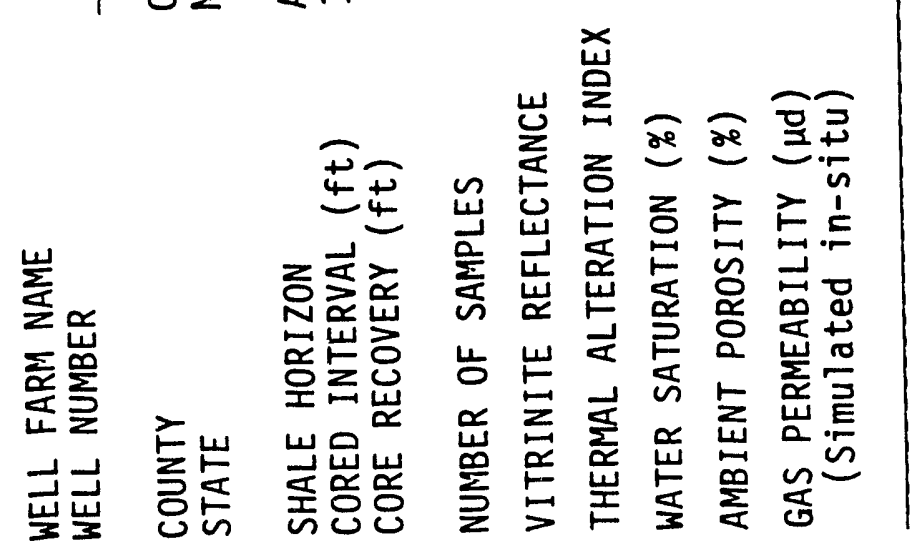




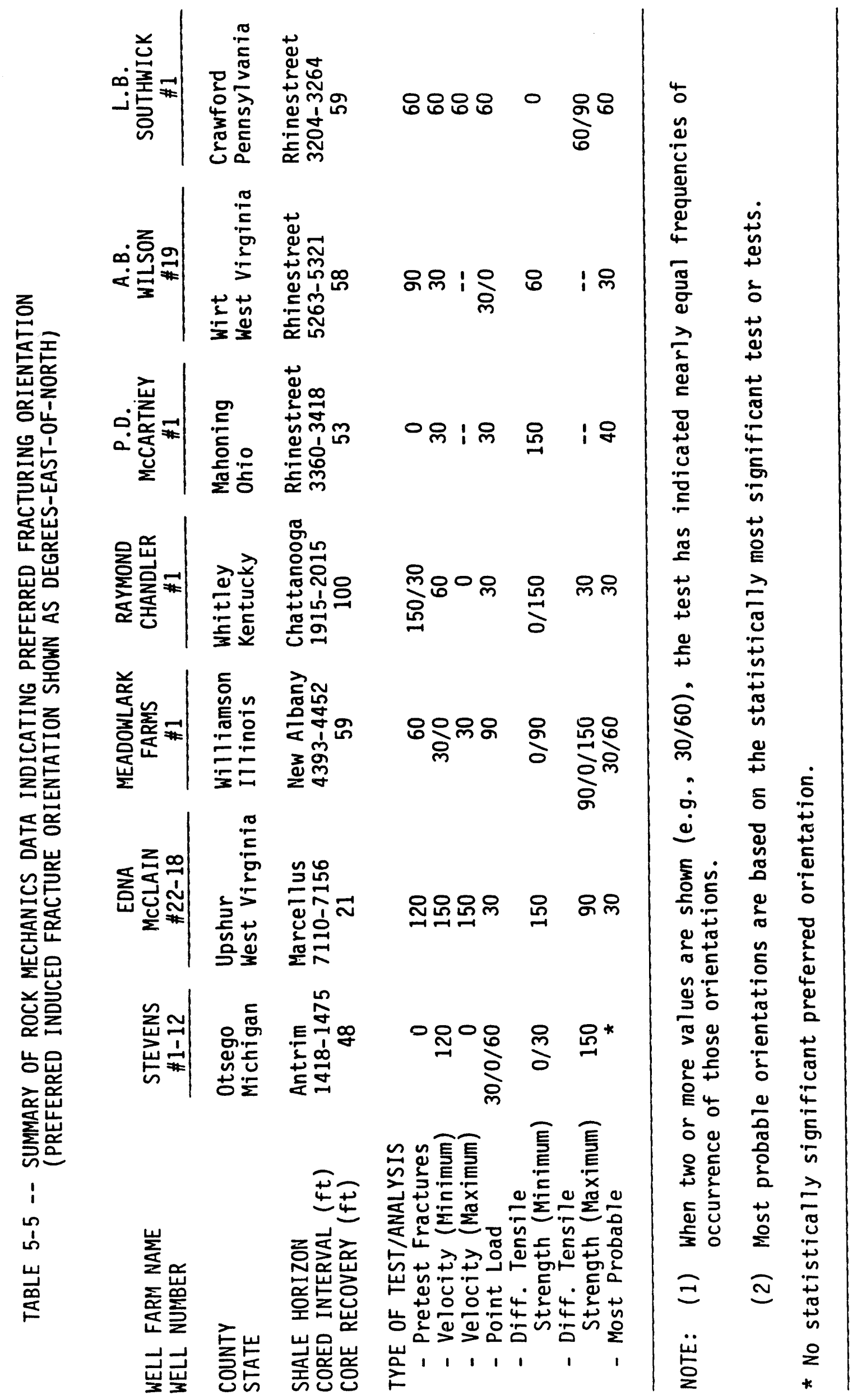




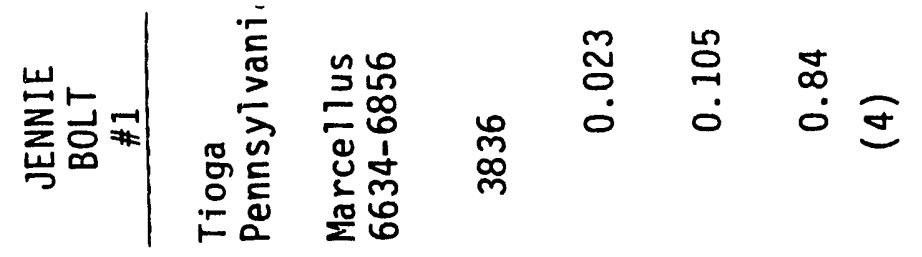

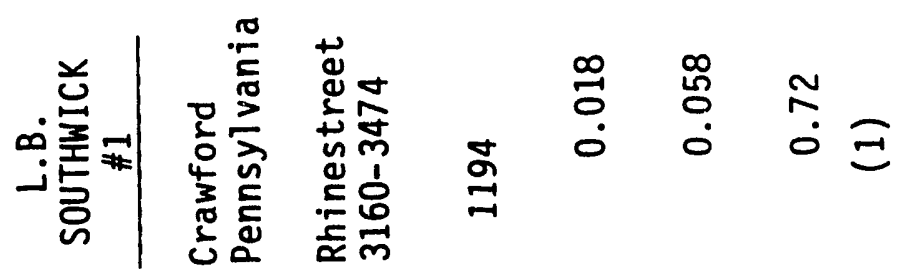

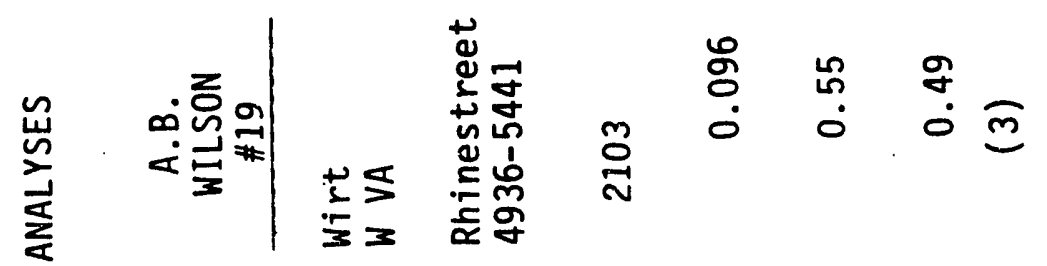

品

항

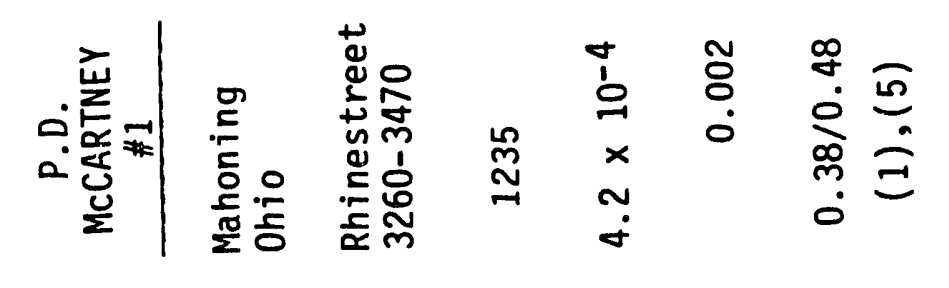

总

崫

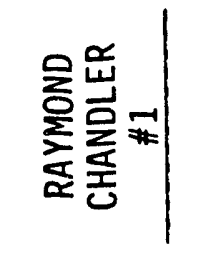

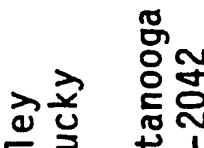

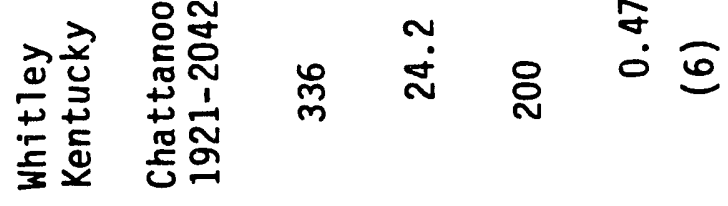

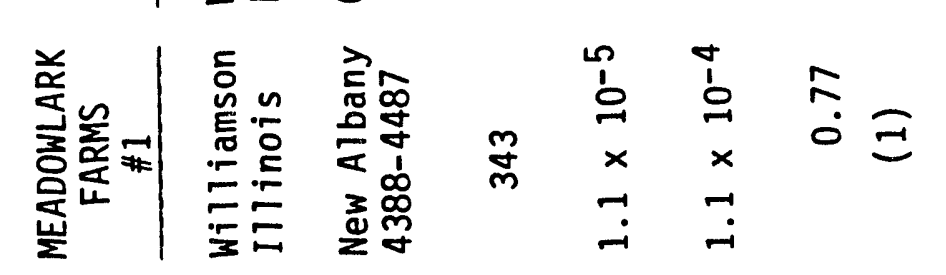

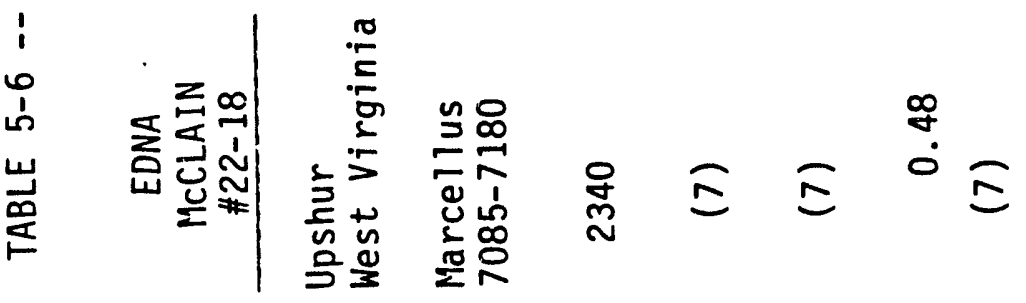

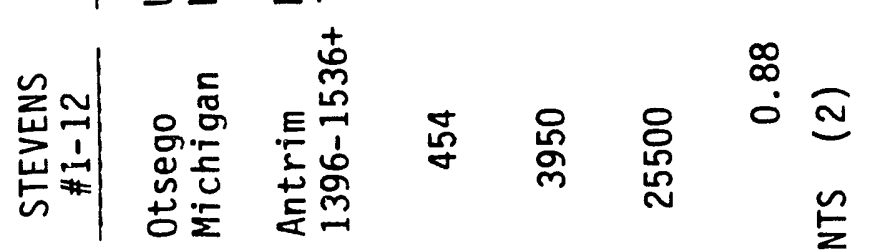

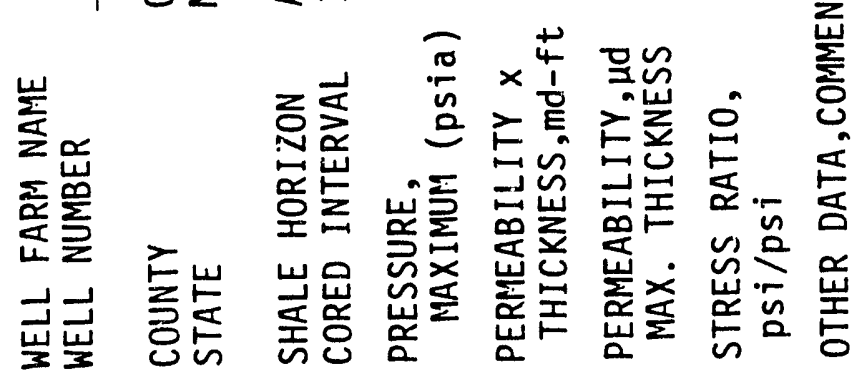


畗=

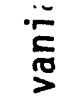

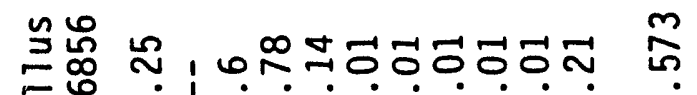

节造过

兽

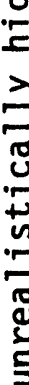

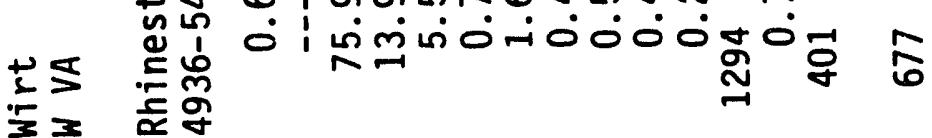

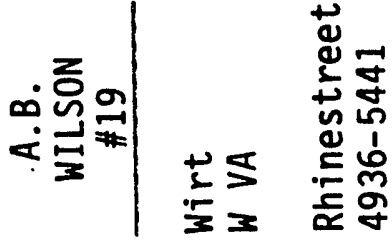

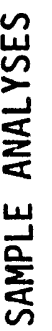

م:

㟧足

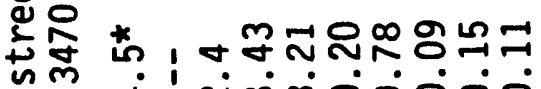

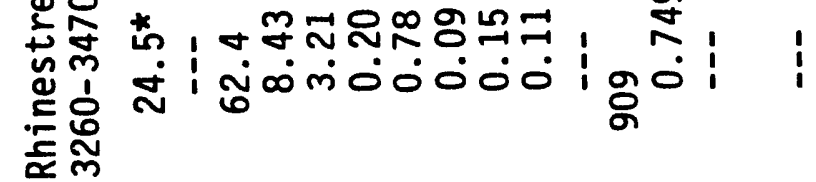

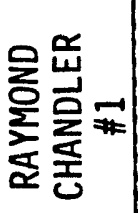

요

궁 융

융 $0,7 \sigma+1050 \%$

넌

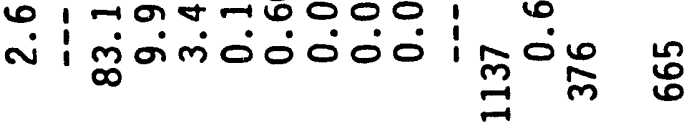

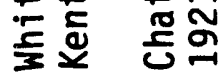

总

ธิ ऐิڤ

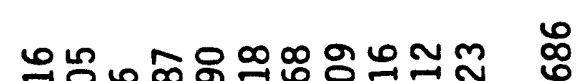

䛠웡

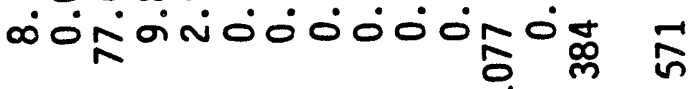

罙年 案曽

这这交交

$\stackrel{.0}{=}$

돈 $\cong$

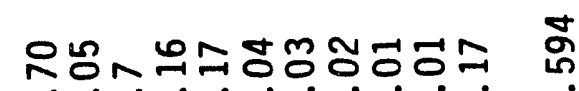

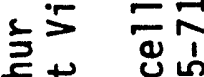

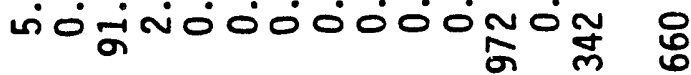

号告 垩员

妾 $\frac{1}{n}$

悎

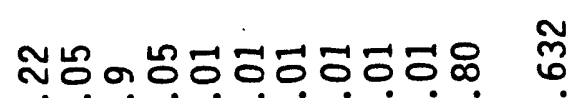

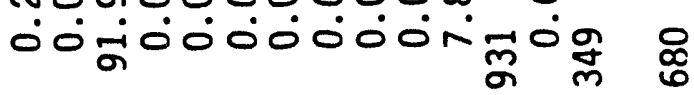

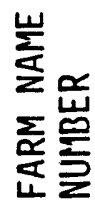

z⿸丆口

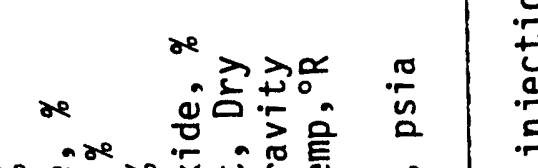

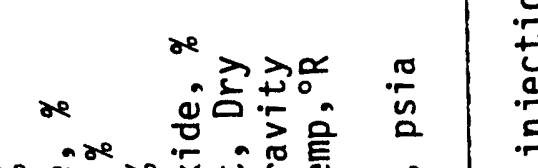

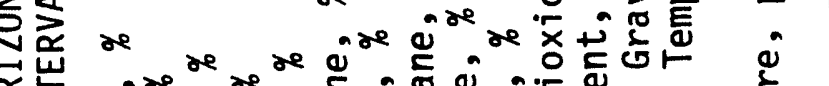

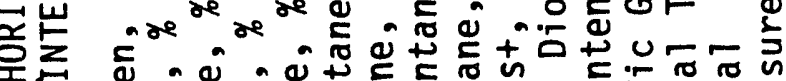

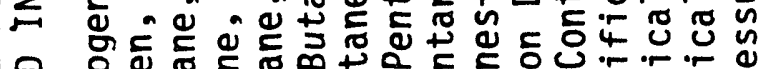

山二 岸

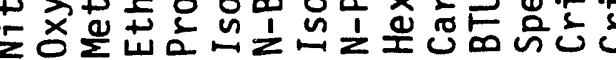




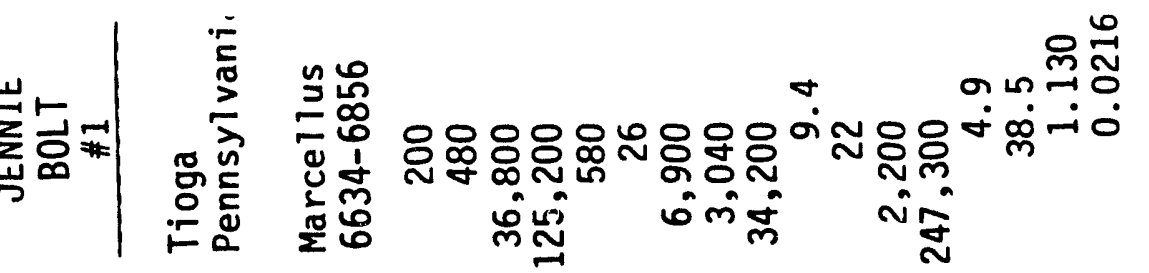

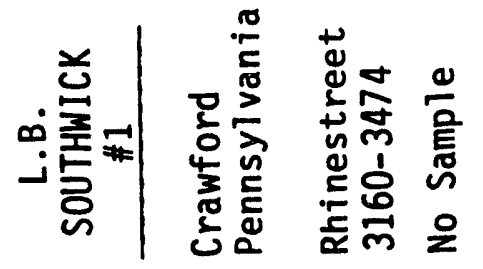

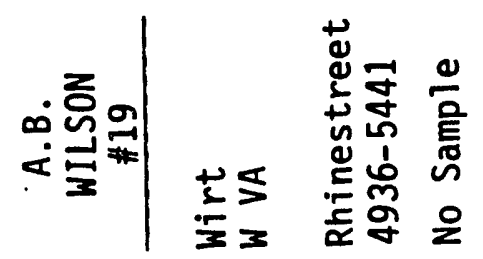

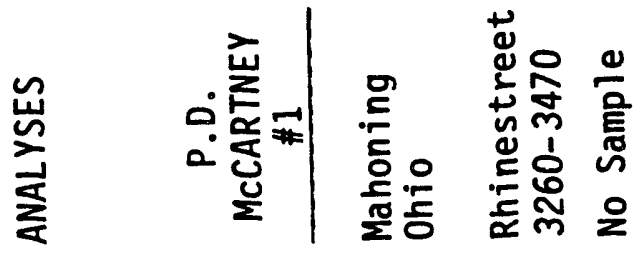

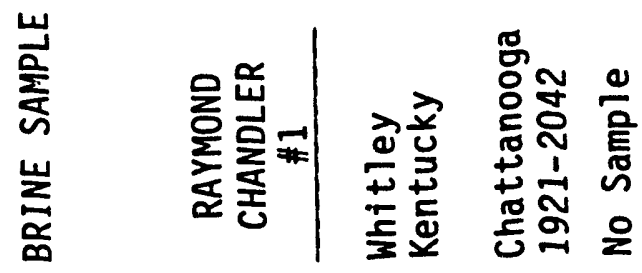

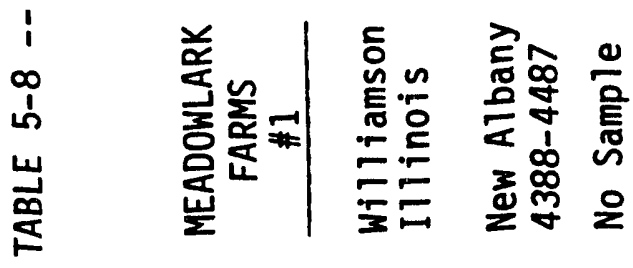

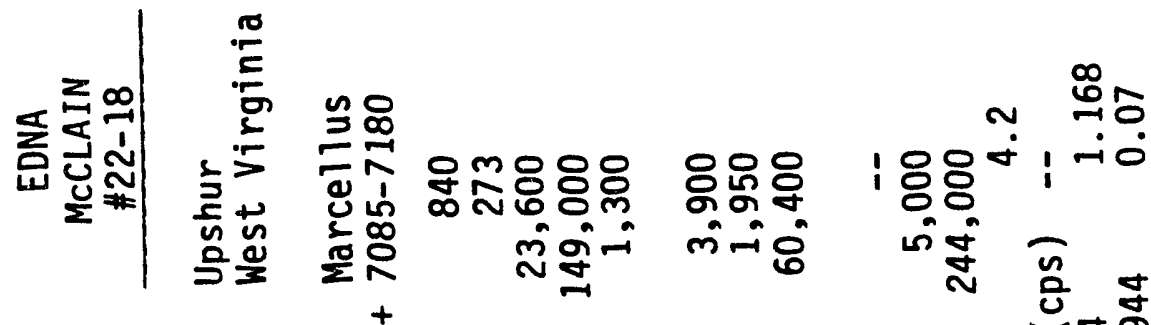

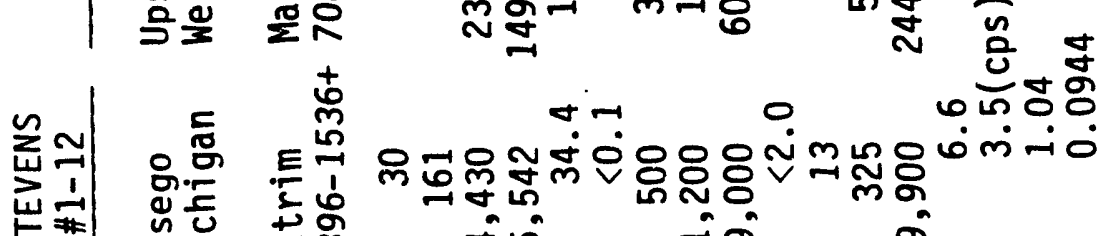

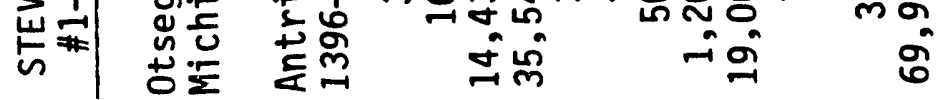

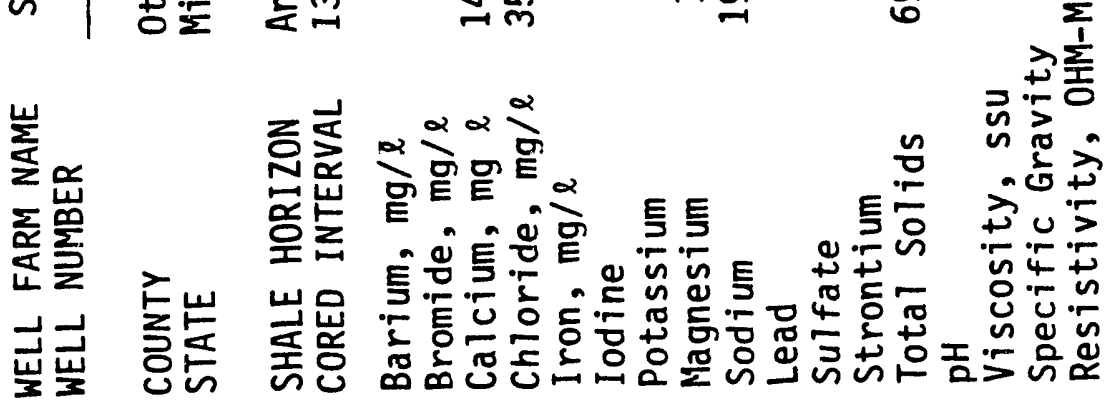




\subsection{Offset Well Test Facility}

Upon selection of the Raymond Chandler Chattanooga Shale gas lease in Whitley County, Kentucky, as the site of the Offset Well Test Facility, a series of tests were conducted to further characterize the site/area as to its reservoir characteristics, natural fracture intensity and orientation, induced fracture orientation, and overall quality. Those tests are described in Section 4.0. This section summarizes the results of the tests.

\subsubsection{Test Site Geology}

Most of the information on the geology of the test site was derived from regional studies and from the fractographic analysis of the core from the Raymond Chandler No. 1 well on the site. Petrophysical and rock mechanics analyses of the core also contributed significantly to the overall understanding of the site geology.

The southeastern portion of Kentucky lies in the maturely dissected Allegheny or Cumberland Plateau portion of the Appalachian Basin. Pennsylvania strata predominates on outcrop in the area, but Devonian shale is exposed at the base of the Pine Mountain Fault. The name Chattanooga shale has been applied to the Upper Devonian shale sequence in eastern Kentucky. Other terms such as the Ohio or Brown shale have been used interchangeably by geologists working in this area. Figure 5-1 shows the stratigraphic relationship among the units in southeastern Kentucky. The Chattanooga or Ohio shale is the result of the coalescing of the Huron shales in Ohio and West Virginia. Figure 5-2 shows the distribution of black shales facies in southeastern Kentucky. As noted in Figure 5-2, the Chattanooga shale is the result of the coalescing of the Huron shales. The thickness of the Devonian shales in southeastern Kentucky also shows a distinct thinning trend from northeast to southwest. In Pike County, near the West Virginia border, it is over 1700 feet thick. In McCreary County, just west of Whitley County, the shales are less than 40 feet thick. Regional isopach maps of the area 


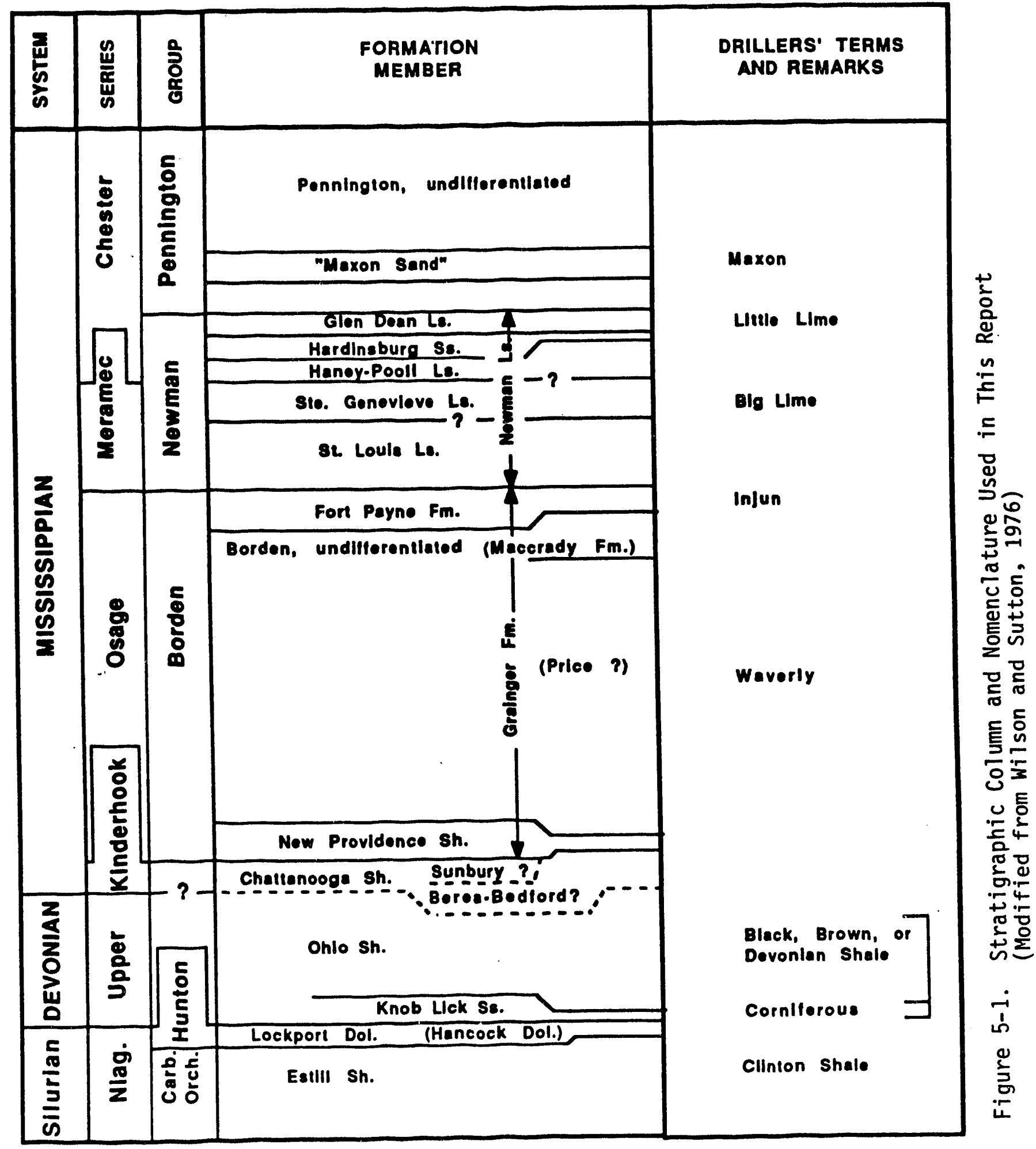




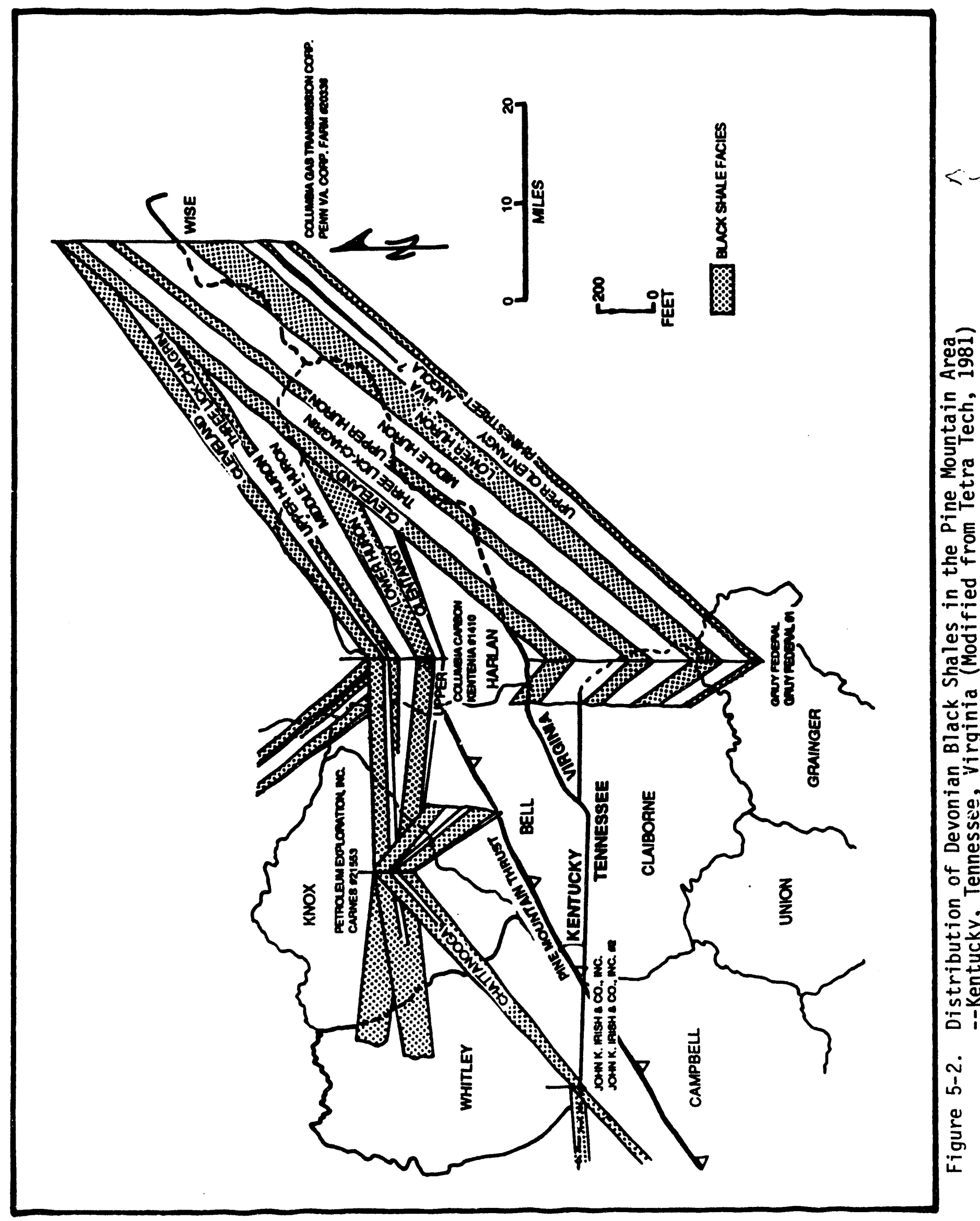


show an essentially uniform thinning trend, although fulton (1979) and Potter (1978) show closed isopachs on what appear to be isolated thick areas within the shale. Several of those thick zones occur in the Big Sandy gas field located in knott and Fletcher counties. Figure $5-3$ is an isopach map of the Chattanooga shale near the well site. The shale in this area also shows a thickened area on the Rockholds and Barboursville quadrangle boundary. A nose-like trend of thick shale is also noted trending off the northeast section of the map. This site appears quite similar to the isolated closed isopachs noted by fulton (1979) and Potter (1978).

The structure in the vicinity of the site appears deceptively simple on structural maps of the area. However, the Pine Mountain Thrust Fault, located 10 to 15 miles southeast of the site, very likely has influenced local geology. Pine Mountain is a decollement zone that developed as a subhorizontal shear that extended for great distances only in incompetent zones and shifted stratigraphic levels upward across short diagonal ramps. Appalachian master decollements such as Pine Mountain generally consist of a series of extensive subhorizontal faults where stratigraphics position changes from lower incompetent Cambrian rocks on the east to higher incompetent Devonian rocks on the west.

An examination of the core taken from the Chandler No. 1 revealec a total of 190 fractures and faults. Sixteen of these faults and fractures within the uppermost two feet of core (1915 to 1917 feet) were in a section of doubtfur core orientation. The 174 fractures and faults in the oriented core section included 44 thrust faults, 73 bedding plane faults, 4 strike-slip faults, 42 disc fractures, 10 petal-centerline fractures and one natural extension fracture. The one natural extension fracture was vertical with a N20E strike and penetrated the core from 1924.0 to 1927.8 feet. Uppermost and lowermost fracture terminations were within the core, and the fracture plane consisted of several coalescing joints. Each coalescing joint plane was mineralized with calcite and fairly smooth and plainer overall. The natural fracture had an 


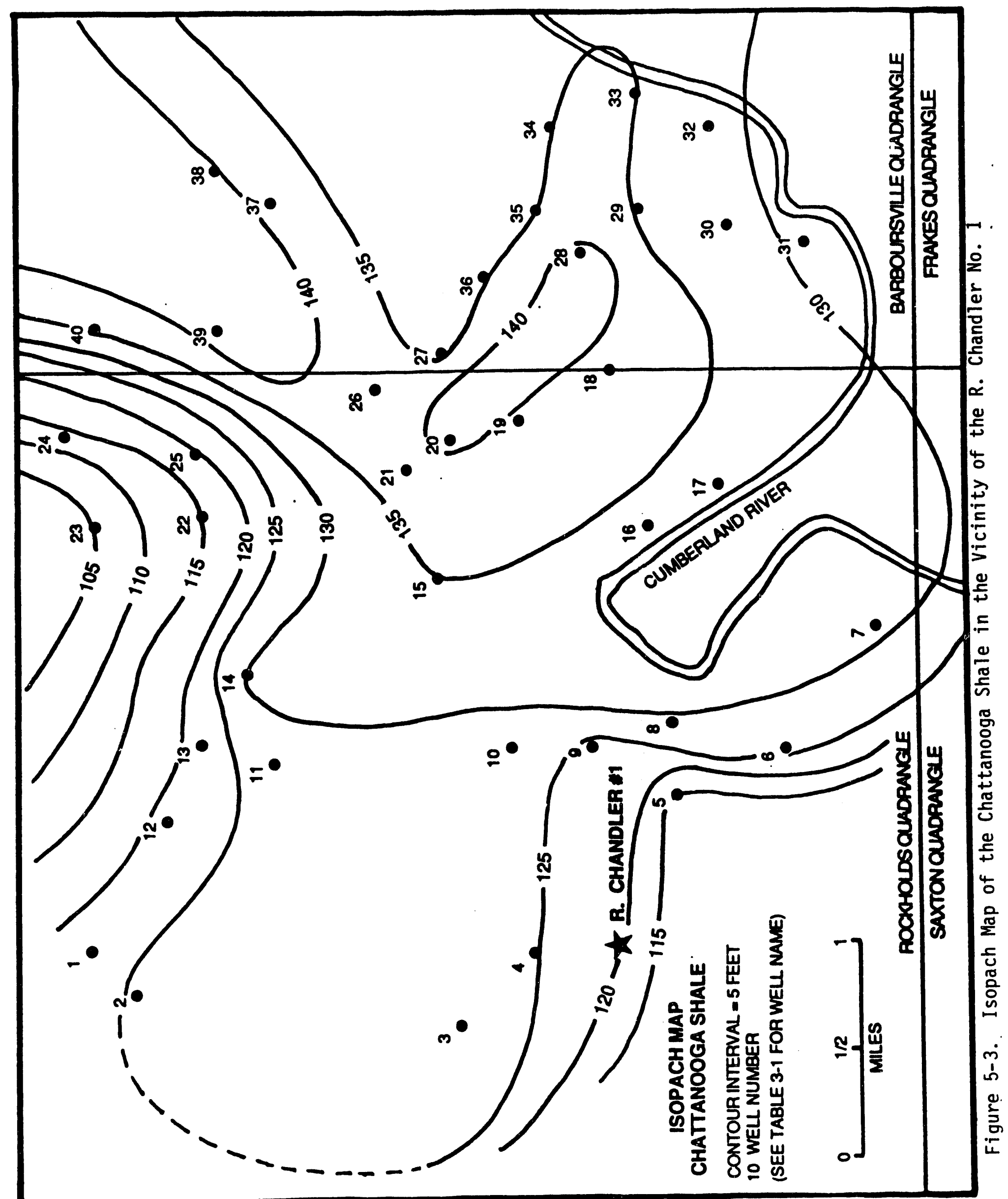


identical orientation to the major trend of the coring-induced petalcenterline fractures (see Figure 5-4). These trends were also observed to be paraliel to the general trend of first-formed Devonian shale outcrop fractures situated to the northwest (Figure 5-5) as shown by Long (1979). The cored natural fracture trend also showed agreement with one of the natural fracture trends in oriented cores from the VA-1 and KY-1 wells (Figure 5-6) as shown by Evans (1979). The cored natural fracture, and those mapped by Long (1979), trend paraliel to regional basin strike and the Cincinnati arch as shown by the Devolian shale isopach map (Figure 5-7). This relationship may indicate that these first-formed fractures reflect down to the basin tensile stresses present during Devonian basin development. If this is so, these natural fractures pre-date Alleghenian deformation.

The pervasive fault geometry and transport directions determined from the core did not completely reflect the geometry and transposition directions of the Pine Mountain sheet. Local lithology and thickness variations of the Devonian shale units in the area may in part be responsible for variations in plume axis orientations, in thrust fault attitudes and slip direction, and in lateral bedding fault movement directions. It is also possible that the cored fault sets and slickenline trends are unrelated to stresses responsible for emplacement of the Pine Mountain sheet.

Several lines of evidence suggest that the basement beneath Whitley county and surrounding areas is a mosaic of previously unrecognized basement faults trending east-west, north-south, northwest and northeast. Regional aeromagnetic data support this hypothesis showing strong preferred magnetic lineaments trending east-west, north-south, N40-60W and N20-40E. Regional gravity data show anomaly lineaments aligned in similar directions. One gravity low occurs over the east-northeast trending axis of Devonian shale thickening shown on Figure 5-7. In addition, Ammerman and Keller (1979) suggest a northwest trending basement structure in eastern Kentucky that may have affected sedimentation into Upper Ordovician and younger rocks. Finally, Thomas (1983) shows basement transform faults within the Virginia promontory and Tennessee embayment that can be projected N50-60W into the area of investigation.

$$
\text { 5- } 15
$$




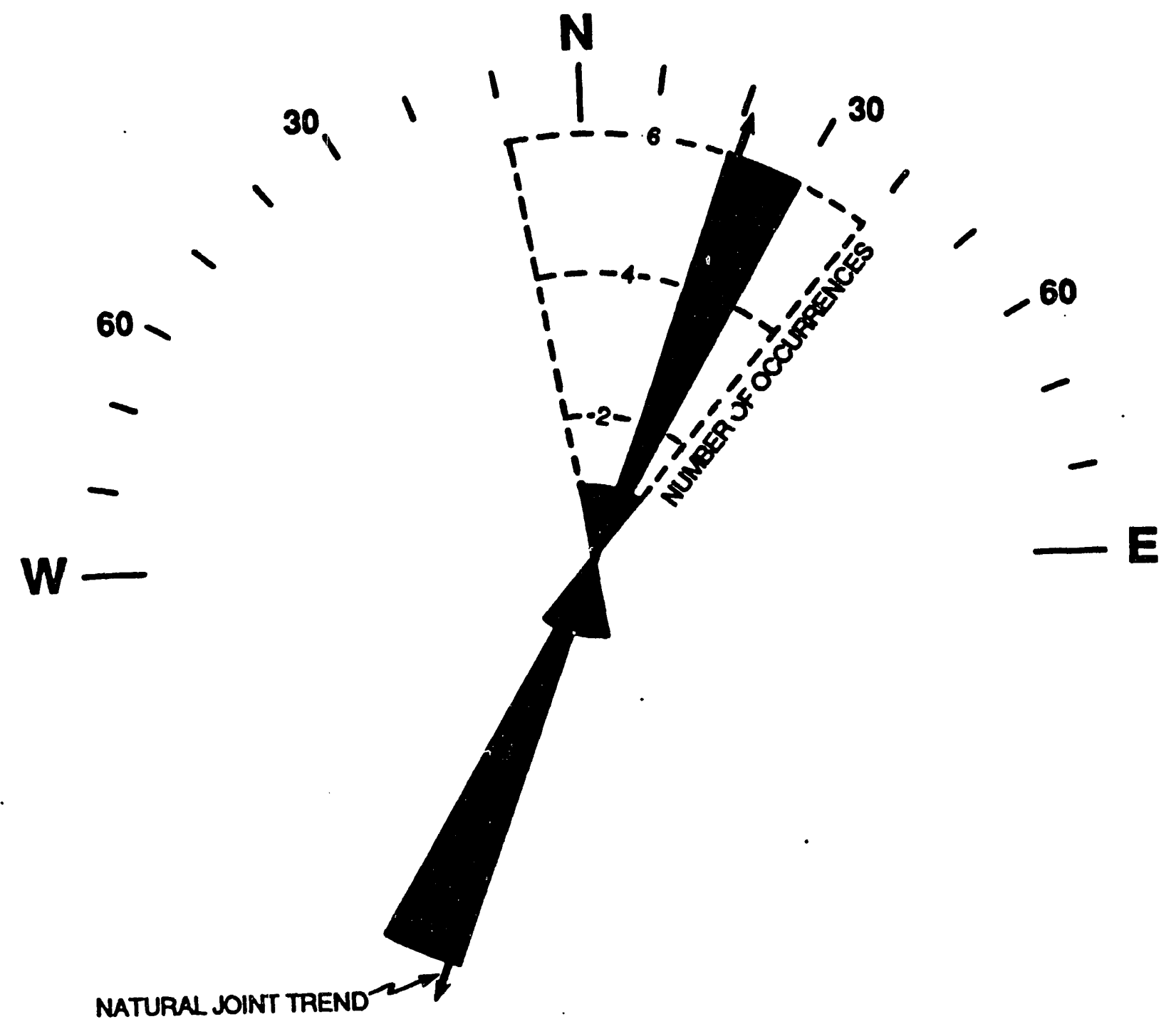

Figure 5-4. Coring-Induced Petal Centerline Strike Directions Including a Single Natural Joint Trend for the R. Chandler No. 1 


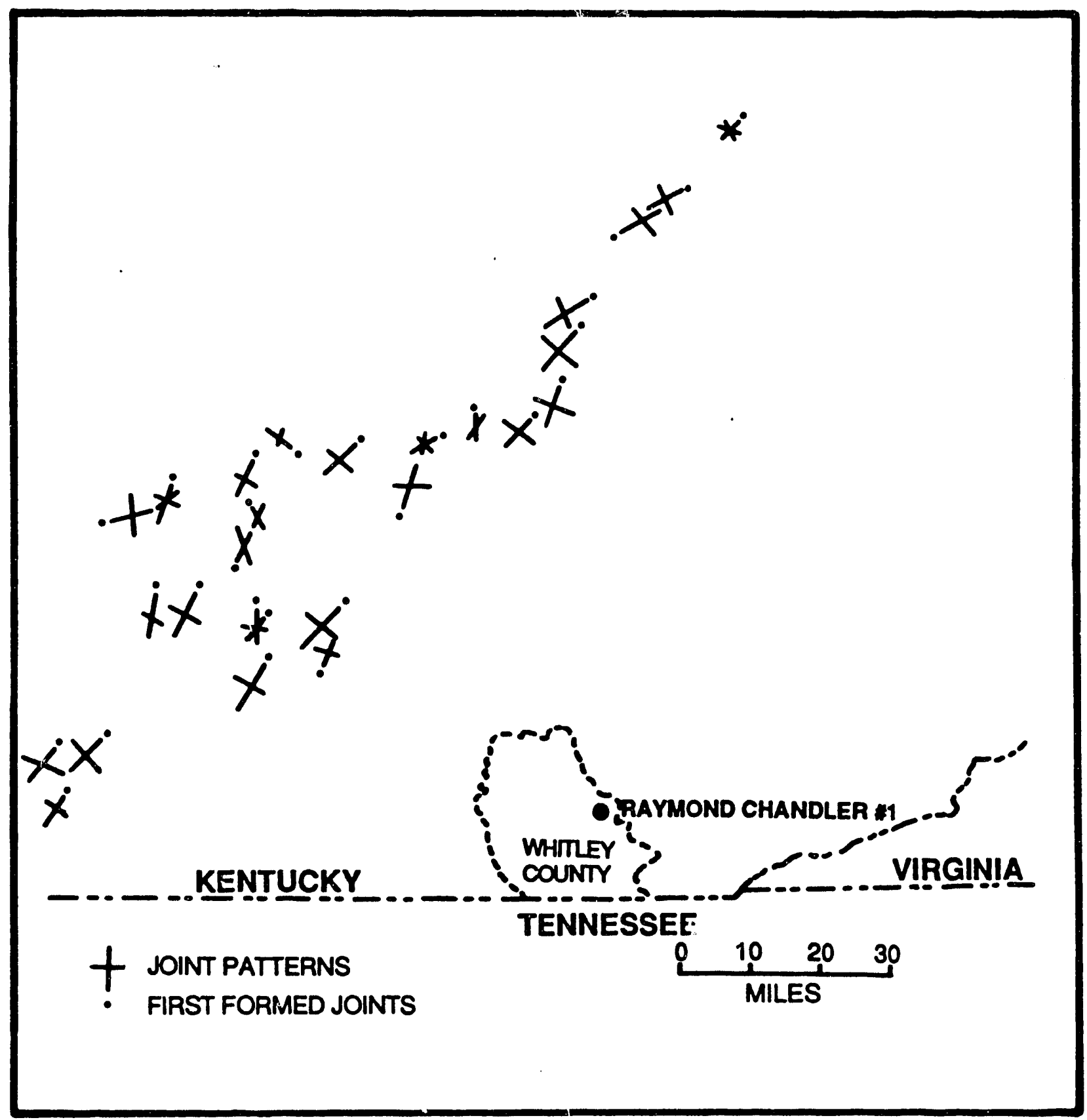

Figure 5-5. Devonian Shale Joints in Outcrop (from Tory, 1979) 


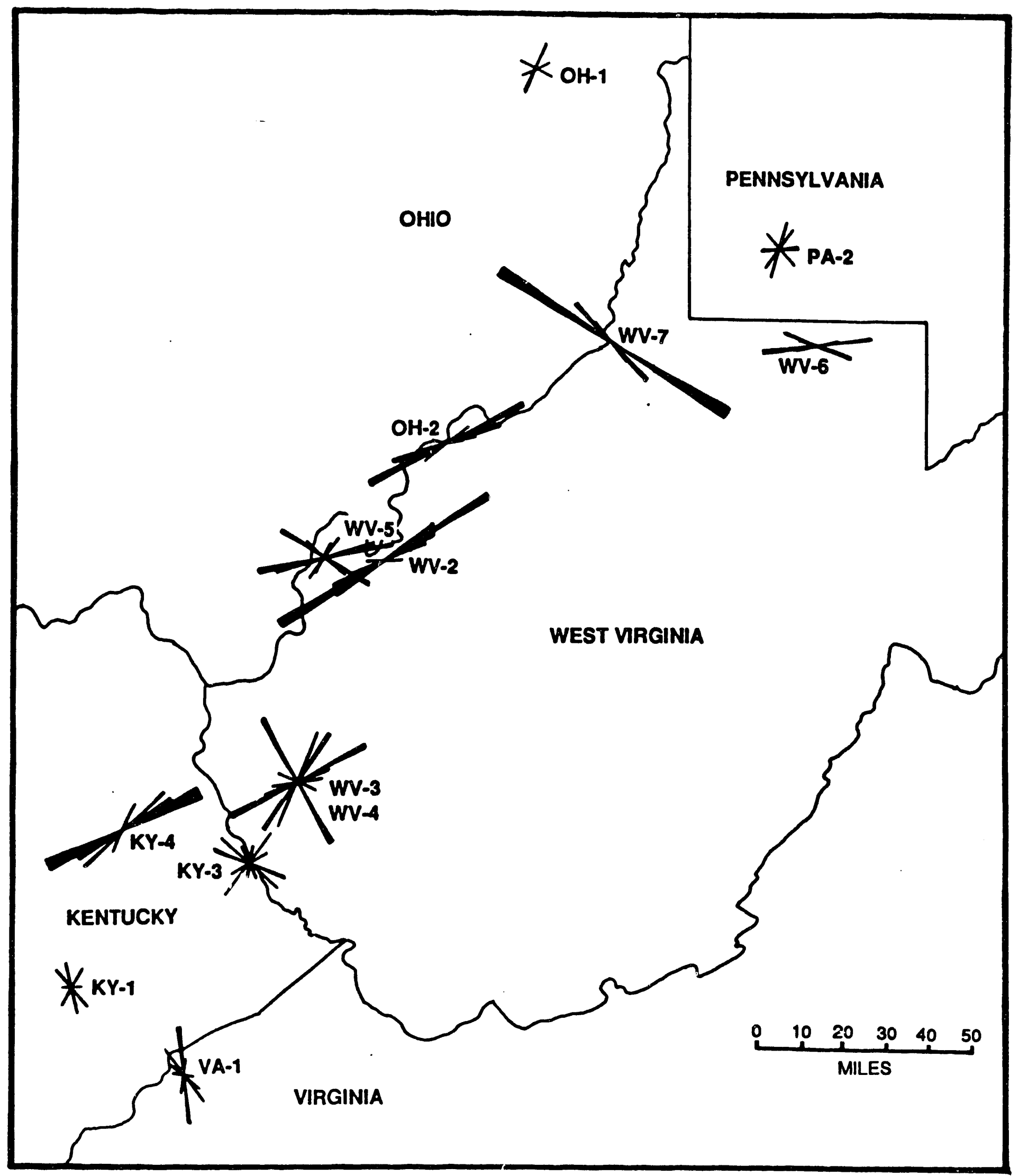

Figure 5-6. Regional Natural Fracture Trends in Devonian Shale Cores (after Evans, 1979) 5-18 


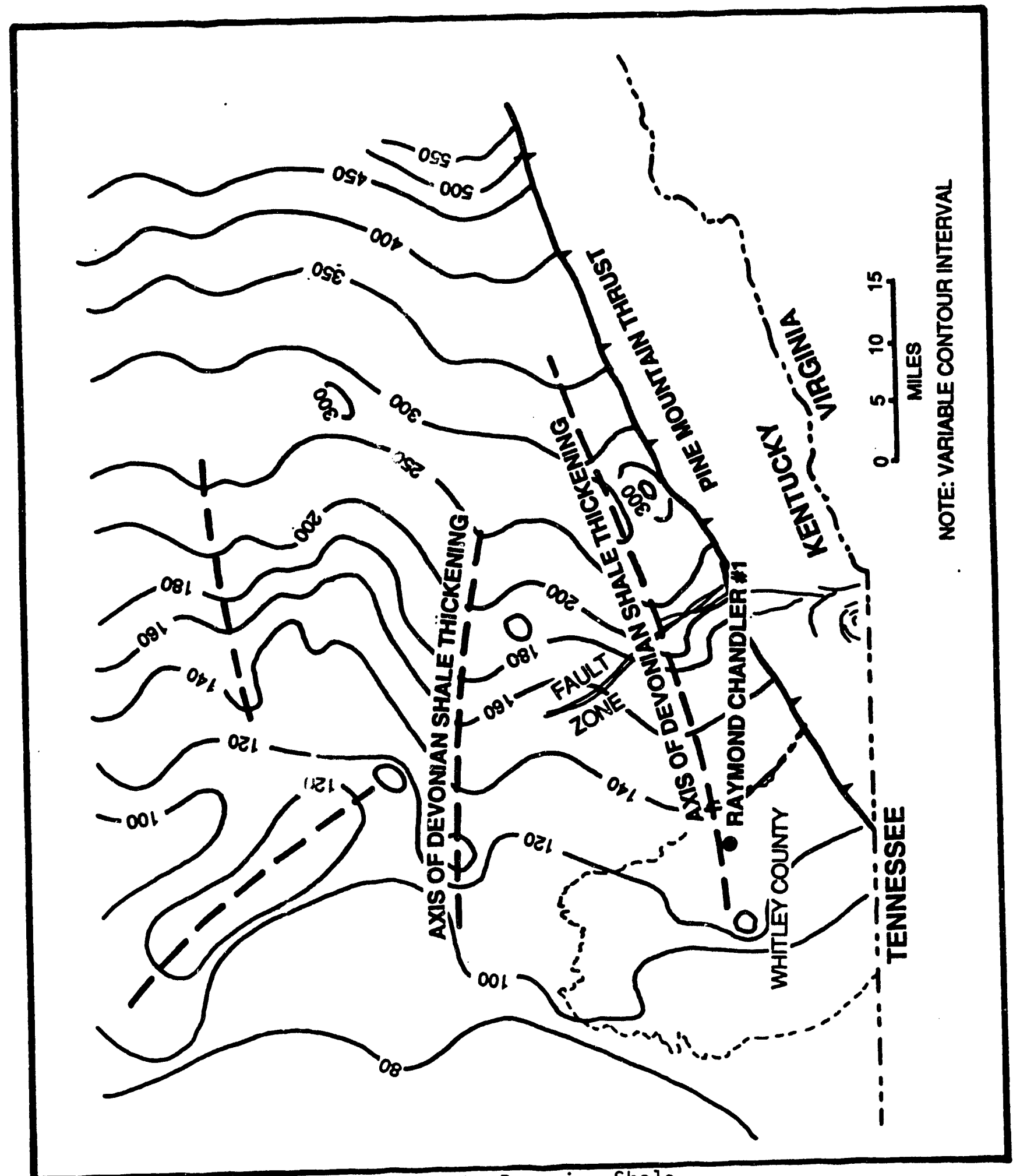

Figure 5-7. Regional Isopach of the Devonian Shale

a ter Schwalb and Potter, 1978) 
A tentative chronology for development of tectonic features in the examined core was postulated as follows: Thrust faults with mean trends $N 15 E, 48 S E$ and $N 46,42 N W$, and related slickenlines may have developed initially in response to a maximum principal stress that was directed along a N58W azimuth. Formation of thrust faults with mean trends of N3OW, 38NE and N4OW, 36SW, and related slickenlines, followed next, and are attributed to lateral stresses oriented N54E. This stress direction is subparallel to in-situ stresses further north as shown by Evans (1979), but are not directly related. Finally, formation of thrust faults with a mean trend of N88W and the conjugate strike-slip faults were formed last in response to stresses acting from $\mathrm{N} 2-18 \mathrm{E}$.

$0 i 1$ and gas occurrences in Whitley and adjoining counties may not be related directly to structures that reflect the geometry of the Pine Mountain sheet. Orientations of many of the faults and slickenlines do not possess a common geometry with this regional structure unless the Pine Mountain decollement has a significant N60W oblique slip component. However, the Raymond Chandler No. 1 core did contain a significant number of thrust faults and bedding plane slip surfaces that can be related to specific tectonic events. It follows that a certain portion of Devonian shale thickening (and thinning) may be related to lateral tectonics as well as possible passive basement control. On the other hand, early regional development of fractures in a subsiding Devonian basin would be unrelated to later horizontal transportatic rooted in these shales. The detection, as well as prediction and projection of specific structural or stratigraphic features that may contain enhanced permeability into adjacent areas is essential for successful hydrocarbon production from Devonian rocks throughout this complex region. 


\subsubsection{Interwe11 Transient Tests at Offset Well Test Facility}

Two types of interwell transient tests were conducted at tre Offset Well Test Facility. These tests are described in Section 4.0 and the results are summarized in this section. In conjunction with the interwell testing, conventional single well tests were conducted and analyzed. These results are also summarized in this section.

The two primary properties or characteristics normally derived from single well tests are reservoir permeability and wellbore damage, or "skin", assuming that certain other properties can be readily estimated (porosity, effective thickness, compressibility, etc.). The results of the single well testing series are shown in Table 5-9. Worthy of note regarding the permeabilities measured at the individual well sites is the much larger permeability $(0.24 \mathrm{md}$ versus $0.06 \mathrm{md})$ calculated for the Raymond Chandler No. 1 well, even though it is only about 125 feet from offset Well No. 1, and no more than 325 feet from any of the offsets. This leads one to speculate on the effects of high degrees of lateral heterogeneity and anisotropy. It is possible that the chandler No. 1 well may have been drilled very close to an intensely-fractured zone resulting in a relatively high calculated value of permeability. The high value for skin would indicate fracture plugging or the absence of fractures near the wellbore.

Two pulse tests were conducted at the site, the first utilizing the Raymond Chandler No. 1 well as the pulsed well and the second utilizing Offset Well No. 1 as the pulsed well. The pressure response curves are shown in Figure 4-7 and 4-8 and the re:jults are shown in Table 5-10. The results of the first test utilizing the hydraulically-fractured Chandler No. 1 well as the pulsed well appears to yield erroneous results and does not appear to have had its values adfquately corrected for the negative skin (induced fracture) existing at the Chandler No. 1 well. Permeabilities appear to be about one order of magnitude too high while porosity values, which should reflect mostly natural fracture porosity, appear to be one to two orders of magnitude too high. 


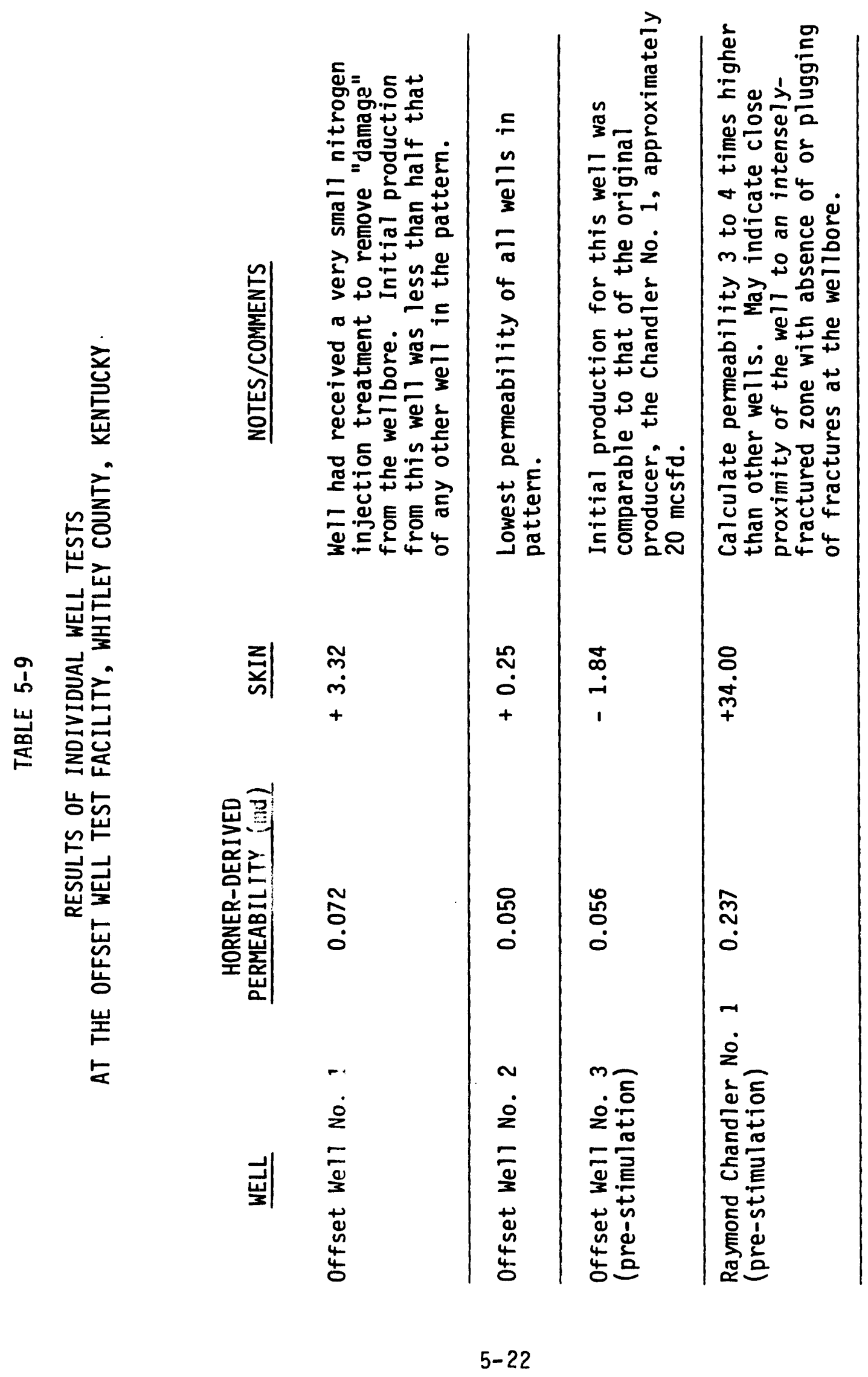


The results of the second test involving only offset Wells No. 1 and 2, both unstimulated wells, yielded results that are very much in agreement with the individual well tests. The permeability value of $0.066 \mathrm{md}$ is exactly the same as the average of the permeabilities of the two wells as calculated from the conventional single well tests. The porosity value of 0.00032 is in general agreement with previous estimates for shale fracture porosity and also represents a reasonable value for the permeability calculated.

An interference test was also conducted using offset Well No. 1 as the producing well while monitoring each of the other wells at the site. Table 5-11 shows the type-curve matching parameters derived for each of the wells in the test. Table 5-12 shows the values for permeability and for the porosity $x$ viscosity $x$ compressibility product. Based on these values and using the calculation procedure documented in Section 9.2 of SPE Monograph 5, Advances in Well Test Analysis, minimum, maximu, and average permeabilities were calculated to be $0.00755,0.990$, and 0.0865 respectively. Maximum permeability direction was calculated to be $N 18^{\circ} \mathrm{E}$, approximately in alignment with the one extension fracture observed in the Chandler No. 1 core and with the coring-induced petalcenterline fractures in the same core (see Figure 5-4).

A second interference test was conducted using offset Well No. 3 as the active well following that well's stimulation by foamfracturing. The results of this test reveal some interesting observations. Not only did the calculated average permeability increase from 0.0865 to 0.364 md (factor of $4 X$ ), but the orientation of maximum permeability was calculated to be $N 30.6^{\circ} \mathrm{W}$ compared to $N 18^{\circ} \mathrm{E}$, a difference of almost 50 degrees. The maximum permeability for this test was calculated to be $1.595 \mathrm{md}$ compared to $0.99 \mathrm{md}$ from the previous test, approximately 1.6 times higher. The minimum permeability was calculated to be 0.083 md, or approximately 11 times greater than the 0.00755 md calculated from the pre-stimulation interference test. The ratio of maximum to minimum permeability decreased from approximately 130 to 20 . The results of this test are summarized in Tables 5-13 and 5-14. A comparison of values between the two tests is shown in Table 5-15. 
TABLE $5-10$

PULSE TEST RESULTS

\begin{tabular}{|c|c|c|c|c|}
\hline \multirow[b]{2}{*}{ RESPONDING WELL } & \multicolumn{3}{|c|}{ TEST NO. 1} & \multirow{2}{*}{$\begin{array}{c}\text { TEST NO. } 2 \\
\text { OFFSET } \\
\text { NO. } 2 \\
\end{array}$} \\
\hline & $\begin{array}{l}\text { OFFSET } \\
\text { NO. } 1 \\
\end{array}$ & $\begin{array}{r}\text { OFFSET } \\
\text { NO. } 2 \\
\end{array}$ & $\begin{array}{r}\text { OFFSET } \\
\text { NO. } 3 \\
\end{array}$ & \\
\hline Time Lag (hours) & 2.78 & 3.08 & 2.23 & 1.82 \\
\hline Pseudo pressure (psiª $/ c p)$ & $15,870.0$ & $33,300.0$ & $27,800.0$ & $115,100.0$ \\
\hline Distance from Pulse Well (ft) & 124.2 & 262.4 & 315.1 & 197.3 \\
\hline Permeability (md) & .81 & .32 & .66 & .066 \\
\hline Porosity & .015 & .0015 & .0015 & .00032 \\
\hline
\end{tabular}

TABLE 5-11

TYPE-CURVE MATCHING PARAMETERS FOR INTERFERENCE TEST NO. 1 USING OFFSET WELL NO. 1 AS THE ACTIVE WELL

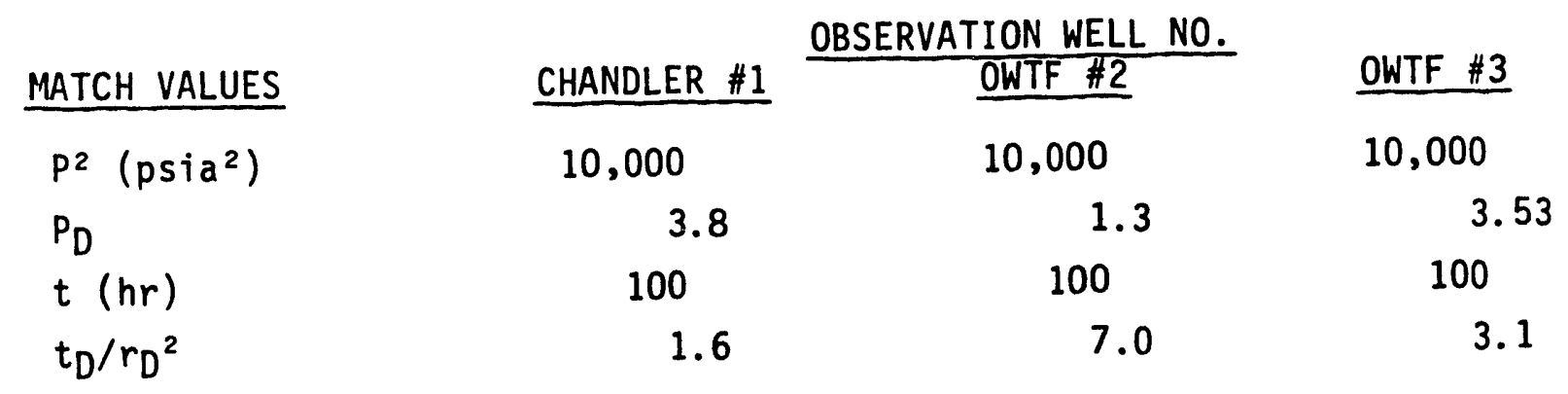

TABLE 5-12

RESULTS OF INTERFERENCE TEST NO. 1 USING OFFSET WELL NO. 1 AS THE ACTIVE WELL

\begin{tabular}{|c|c|c|c|}
\hline \multirow[b]{2}{*}{ PARAMETER } & \multicolumn{3}{|c|}{ WELL NUMBER } \\
\hline & CHANDLER \#1 & OWTF \#2 & OWTF \#3 \\
\hline *Distance, $r(f t)$ & 124.2 & 196.5 & 211.0 \\
\hline Permeability, $K(m d)$ & 0.219 & 0.087 & 0.228 \\
\hline$\phi \mu C_{t}\left(d p-p s i a^{-1}\right)$ & $2.34 \times 10^{-7}$ & $8.49 \times 10^{-9}$ & $4.36 \times 10^{-8}$ \\
\hline Thickness, $h(f t)$ & 121.0 & 104.0 & 108.0 \\
\hline
\end{tabular}


TABLE 5-13

TYPE-CURVE MATCHING PARAMETERS FOR INTERFERENCE TEST NO. 2 USING HYDRAULICALLY-FRACTURED OFFSET WELL NO. 3 AS THE ACTIVE WELL

MATCH VALUES

$p^{2}\left(p s i a^{2}\right)$

$P_{D}$

$t(h r)$

$t_{D} / r_{D}^{2}$

CHANDLER \#1 $\frac{\text { OBSERVATION WELL NO. }}{\text { OWTF \#2 }}$

100,000

5.8
1,000
74

100,000

4.4

1,000

24.5
OWTF \#3

100,000

5.2

TABLE 5-14

RESULTS OF INTERFERENCE TEST NO. 2 USING HYDRAULICALLY-FRACTURED OFFSET WELL NO. 3 AS THE ACTIVE WELL

PARAMETERS

*Distance, $r(f t)$

Permeability, $K(\mathrm{md})$

$\phi \mu C_{t}\left(c p-p s i a^{-1}\right)$

Thickness, $h(f t)$
CHANDLER \#1

315.5

0.394

$1.41 \times 10^{-8}$

121
OWTF \#1

211

0.344

$8.32 \times 10^{-8}$

105

\section{OWTF \#2}

111

0.410

$15.9 \times 10^{-8}$

104

TABLE 5-15

COMPARISON OF RESULTS OF INTERFERENCE TESTS NO. 1 AND 2 AT THE OFFSET WELL TEST FACILITY, WHITLEY COUNTY, KENTUCKY

TEST NO.1

TEST N0.2

(OFFSET WELL \#1 ACTIVE) (OFFSET WELL \#3 ACTIVE)

Maximum Permeability (md)

0.9895

1.595

Minimum Permeability (md)

0.0075

0.083

Average Permeability (md)

0.0865

0.364

$\emptyset \mu C_{t}\left(c p-p s i a^{-1}\right)$

$5.43 \times 10^{-8}$

$7.79 \times 10^{-8}$

Direction of Max. Perm.

$\mathrm{N} 18^{\circ} \mathrm{E}$ $\mathrm{N} 31.6^{\circ} \mathrm{W}$

Ratio Max/Min Perm. 


\subsubsection{Induced Fracturing and Fracture Diagnostics}

Offset Well No. 3 was stimulated to provide a comparison of limited-entry single-stage fracturing with the 2-stage treatment used to stimulate the Chandler No. 1 well and to provide an opportunity to obtain information concerning the probable orientation of induced fractures in the area. This test and the utilization of tiltmeters and other resources for estimating fracture geometry is described in Section 4.0.

The increase in productivity of offset Well No. 3 indicates that the single-stage limited-entry technique was as successful as the original 2-stage technique employed. Where economically feasible, the recommended completion technique, therefore, would be to set casing through the Chattanooga and selectively perforate using a minimum number of holes for better control of frac fluids.

Prior to the stimulation of Offset Well No. 3, tiltmeters had been installed at the site to monitor earth surface tilts and to estimate fracture geometry. The tilt vectors that resulted from the stimulation are shown in Figure 5-8. The tilts were analyzed by Hunter Geophysics, Inc., who had provided the field instrumentation and operation, first using a single-fracture source model and later using a dual-fracture model. The single-fracture solution had a minimum "mean square error" for the single fracture trending $N 30^{\circ} \mathrm{E}$ and dipping $70^{\circ}$ to the northwest. This orientation is supported by the rock mechanics information derived from core tests. Sites 5, 6, 7, and 11 were found to consistently contribute over $50 \%$ of the total error for each solution and were subsequently eliminated from the analysis.

The magnitude of the residual error associated with the single fracture solution was observed to be relatively large, indicating that a more complex induced fracture system was probabiy created. Hunter Geophysics extended their analysis to a dual-fracture system which reduced the error significantly. The best solution for the dual-fracture model described one of the fractures as trending $\mathrm{N} 35^{\circ} \mathrm{E}$ and vertical, while the other fracture was nearly horizontal, trending 


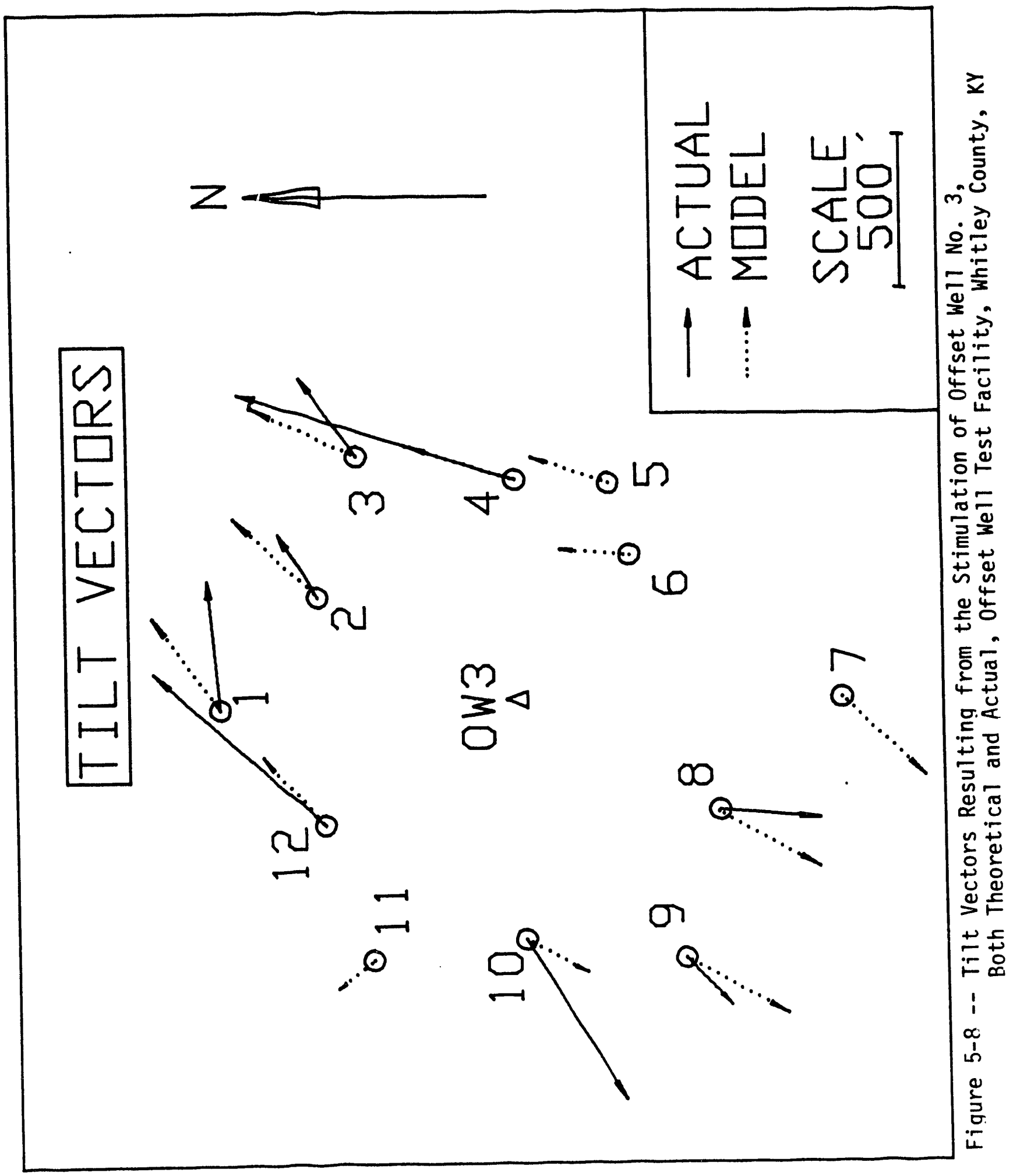


due north/south and dipping just 10 degrees to the west. Again, the tiltmeters at sites $5,6,7$, and 11 were strong contributors to the error and were eliminated from the analysis.

The tiltmeter signals were observed to be relatively linear during the entire injection period. This indicates that fracture growth was uniform over the life of the job and that if there were, in fact, two fractures as described by the models, they were propagated simultaneously. For a nearly horizontal and vertical fracture to grow at the same time, the vertical and horizontal stress components would have to be nearly equal. Prior estimates of the minimum horizontal stress component(s) compared to the vertical or overburden stress do not support the propagation of a horizontal fracture. The stress ratio value of 0.53 or less as determined from stress tests on the Chandler No. 1 and from nitrogen injection tests on offset Wells No. 1 and 3 would be considerably too low for simultaneous propagation of a vertical and a horizontal fracture. However, tiltmeter responses should be interpreted in conjunction with other information which may be available; therefore, pressure observations during stimulation should be analyzed and considered in the tiltmeter interpretation as should the prior and subsequent interference testing.

Pressure responses were observed in all monitoring wells as seen in Figure 4-17. Well OW-1, 211 feet $(64.3 \mathrm{~m})$ and $N 8^{\circ} \mathrm{W}$ of $\mathrm{OW}-3$, responded first with a gradual but definite increase in pressure that was still increasing 17 hours into the test and well after flowback was begun at the stimulated we11. The response at 0 - 1 supports the tiltmeter postulated north-south trending fracture.

Well 0 W-2 responded later than $0 W-1$, but with a higher amplitude than either $\mathrm{OW}-1$ or $\mathrm{RC}-1$. $\mathrm{OW}-2$ is located much closer to $\mathrm{OW}-3$ than either of the other two monitoring wells, 111 feet $(33.8 \mathrm{~m})$ and $\mathrm{N} 75^{\circ} \mathrm{W}$ of $\mathrm{OW}-3$. The relatively high pressure response in $0 \mathrm{~W}-2$ coupled with the relatively rapid response in $0 W-1$ also supports the tiltmeter data in that frac fluids appear to have invaded the reservoir more or less radially, as would happen in the case of a horizontal fracture. 
The pressure response at $\mathrm{RC}-1$, the most remote well at 315 feet $(96.0 \mathrm{~m}) \mathrm{N} 23^{\circ} \mathrm{W}$ of $\mathrm{OW}-3$, was similar to that of $0 \mathrm{~W}-1$ in shape, but lower and having an earlier maximum. The initial response time at OW- 1 was about the same as that of $0 W-2$, but had a much lower rate of build. The increased pressure at $R C-1$, like that of $0 W-1$, was sustained much longer than that of $0 \mathrm{~W}-2$.

Little additional insight is provided by the pressure responses at the observation wells except that a significant pressure wave was propagated through the reservoir fairly quickly. Palmer (1988) has shown that surface tilts from a transient pressure wave such as this can be significant and may emulate a horizontal fracture with respect to measured surface tilts.

The increase in calculated permeability and the rotation of apparent maximum permeability as determined from Interference Test No. 2 (post-stimulation) as compared to Interference Test No. 1 (prestimulation) may also shed some light on the issue. The apparent increase in permeability in the north-westerly direction may indicate the simultaneous propagation of two (or more?) vertical fractures; one being to the northeast as calculated from the tiltmeter analysis, and one to the northwest as may be indicated by the apparent shift in direction of the maximum permeability. It should also be noted that the data from tiltmeters $\# 5,6,7$, and 11 could not be reconciled by the computer code used in analyzing the tilts, even though a qualitative evaluation of their responses indicated that those tiltmeters were, in fact, responding to the frac treatment on Offset Well No. 3. Tiltmeters 5, 6, 7, and 11 are all in the northwest-southeast quadrants relative to offset Well No. 3 .

\subsubsection{Big Lime and Devonian Shale Interaction}

No conclusive evidence could be found to prove the hypothesis that the Big Lime and Devonian shale formations are in communication and/or was interfering with the Offset Well Test Facility wells. Figure 9-20 shows the pressure history and history match for the Chandler No. 2. 
Figure 5-9 shows well pressures monitored in the Chattanooga Shale during a drawdown test being conducted on offset Well No. 3. The pressure response at the Chandler No. 1 well was not typical of the response expected for an undisturbed interference test; however, if the Big Lime well (R. Chandler No. 2) did affect the pressures on the Devonian, the cause would have been the shut-in that occurred at time $=72$ days in Figure 4-20, approximately 24 days prior to the observation in the Chattanooga. It should be noted also that the abnormal pressure deviation was observed only in the Charidler No. 1 well and not in any of the offset wells.

\subsection{Conclusions}

A wide range of reservoir parameters were found for the various Devonian shale formations tested. Core (rock matrix) permeabilities generally fell in the same range as the permeabilities determined in prior work. Porosities, likewise, were similar. Both Rhinestreet shale and Marcelius shale formations indicated somewhat higher porosities than the Huron shales, the most common producing horizon, ranging from 2-5 percent for the Rhinestreet and up to 10 percent for the Marcellus, compared to 1-4 percent for the Huron. Neither the Rhinestreet nor the Marcellus were significantly more permeable as a result of the higher porosity values because little of the porosity was interconnected. As a result, the same criteria exist for the successful development of a natural gas resource within these horizons as is the case for the Huron; i.e., natural fracture development is essential for commercial gas production. Stimulation of a well in an area of undeveloped or poorly developed natural fractures will not generate sufficient reserves for commercial production.

The Chattanooga Shale at the Whitley County, Kentucky, Offset Well Test Facility site was determined to be highly-fractured and faulted. Even so, permeability was very low (less than 0.2 md average) and stimulation by hydraulic fracturing is necessary for commercial production. Porosity is low for the Chattanooga, between one and two percent, and 


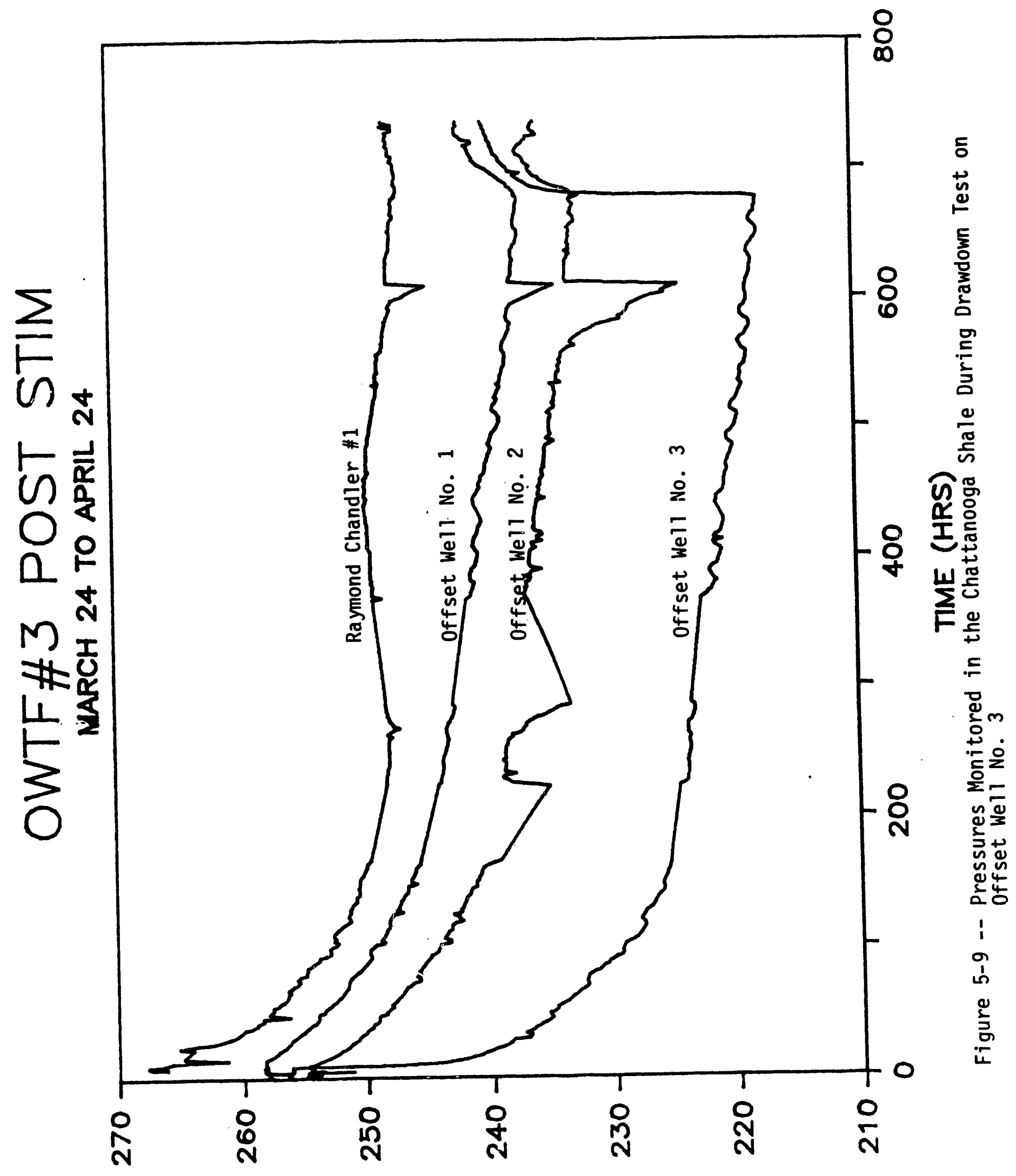

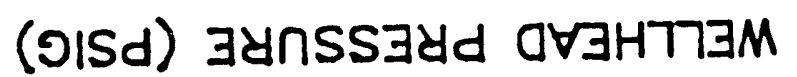


gas content by adsorption is also relatively low because of the low reservoir pressure (approximately $300 \mathrm{psi}$ ). Gas can be produced commercially, however, from ine Chattanooga because of the fact that there are other gas productive zones in close proximity to the Chattanooga, particularly the "Big Lime" and the Waverly shale.

Fracture diagnostics were inconclusive, but the probable orientation of a hydraulic fracture induced in the Chattanooga Shale at the offset well site is $N 30-35^{\circ} \mathrm{E}$. Rock mechanics tests revealed several possible orientations for induced fractures, but favored the northeasterly trend. Tiltmeter analysis indicated $N 35^{\circ} \mathrm{E}$, but could not resolve tilts that occurred at tiltmeter sites along a northwesterly trend. Initial well interference tests indicated a northeasterly permeability trend, but tests conducted after the stimulation of offset Well No. 3 showed a northwesterly trend. Permeability anisotropy from the latter interference test was calculated to be approximately $20: 1$.

Outgassing experiments revealed little regarding the role or extent of desorption of gas from shales. Gas desorbed from cores during the outgassing experiments was typically much richer in heavier hydrocarbon components than was the gas produced from cored well itself. Gas contents were in the typically-expected ranges of 0.5 to 3 standard volumes of gas per volume of rock sample, but probably did not accurately reflect total in-situ gas content, particularly methane, the predominant component of the produced gas.

In general, the results of the investigations conducted under this program were similar to those of previous studies. Natural fractures within the shales contain nearly all of the permeability of the reservoir but contain only a small part of the natural gas resource. clearly, the areas of concentration for future exploration and development R\&D should be directed toward the technologies to detect and/or predict the occurrence of naturally-fractured zones and to improve the ability to connect with these zones through such techniques as improved hydraulic fracturing and/or directional drilling. 


\subsection{REFERENCES}

Anderson, O.L., and Liebermann, R.C., 1966, Sound Velocities in Rocks and Minerals. VESIAC State-of-the Art Report 7885-4-X. Willow Run Laboratories, Univ. of Michigan, $182 \mathrm{p}$.

Birch, F., 1968, The Velocity of Compressional Waves in Rocks to 10 Kilobars. Part I. J. Geophys. Res., v.65, p. 1083-1102.

Cliffs Minerals, Inc., 1982a, Geologic Analysis of Devonian Shale Cores; report prepared for DOE/EGSP, DOE/METC/08199-1130.

Cliffs Minerals, Inc., 1982b, Anaiysis of the Devonian Shales in the Appalachian Basin; Vol. II Report Prepared for DOE/EGSP/METC, Contract No. DE-AC21-9-MC14693, 314 p.

Earlougher, R.C., Jr., 1977, Advances in Well Test Analysis; SPE^IME, New York, p 131-155.

Evans, M.A., 1979, Fractures in Oriented Devonian Shale Cores from the Appalachian Basin, unpublished Master's thesis, West Virginia University, Morgantown, $278 \mathrm{p}$.

Fulton, L. P., 1979, Structure and Isopach Map of the New Albany Chattanoga - Ohio (Devonian and Mississippian) in Kentucky: Eastern Sheet; Kentucky Geological Survey, Series XI, University of Kentucky, 1 Sheet.

GangaRao, H.V.S., Advani, S.H., Change, P., Lee, S.C., and Dean, C.S., 1979, In-situ Stress Determination Based on Fracture Responses Associated with Coring Operations; 20th U.S. Symposium on Rock Mechanics, Austin, Texas.

Gregg, W.J., 1986, Mechanical Fabric and In-situ Stress Orientations in the Devonian Gas Shales of The Appalachian Basin in Rock Mechanics: Key to Energy Production; Proc. 27 th U.S. Symposium on Rock Mechanics, p. 709-715.

Harris, L.D., 1970, Details of the thin-skinned tectonics in parts of the Valley and Ridge and Cumberland Plateau provinces of the southern Appalachian, in G.W. Fisher, F.J. Pettijohn, J.D. Reed, Jr., and K.N. Weaver, eds., Studies of Appalachian Geology: Central and Southern: New York, Wiley-Interscience, p. 161-173.

Johnson, R.W., Jr., Haygood, C., Hildenbrand, T.G., Hinze, W.J., and Kunselman, P.M., 1980, Aeromagnetic map of the east-central midcontinent of the United States, U.S. Nucl. Regul. Comm. Rep., NUREG/CR-1663, $12 \mathrm{p}$. 
Komar, C.A., and Kovach, S.J., 1969, Directional Ultrasonic Pulses Orient Failure Planes in Sedimentary Rocks, W. Va. Acad. Sci., West Liberty, W.Va., Abstract.

Komar, C.A., Overbey, Jr., W.K., Watts, R.J., 1976, Prediction of Fracture Orientation from Oriented Cores and Aerial Photos; West Poison Spider Field, Casper, Wyoming, U.S. Energy Res. and Dev. Admin.

Kulander, B.R., Burton, C.C., and Dean, S.L., 1979, The Application of Fractography to Core and Outcrop Fracture Investigations, U.S. DOE METC/SP-79/3, 174 p.

Kuuskra, V.A., Sedwick, K.B., Thompson, K.B. and Wicks, D.E., 1985, Technically Recoverable Devonian Shale Gas in Kentucky; Lewin and Associates, Inc., Report DOE/MC/19239-1834 Prepared for DOE/METC Under Contract No. DE-AC21-82MC-19239.

Long, B.R., 1979, Regional survey of surface joints in eastern Kentucky, unpublished Master's thesis, West Virginia, Morgantown, p. 68.

McWilliams, J.R., 1966, The role of Microstructure in the Physical Properties of Rock; ASTM STP 402, p. 175-189.

Mellor, M., and Hawkes, I., 1971, Measurement of Tensile Strength by Diametral Compression of Discs and Annuli; Engrg. Geol., v. 5, p. 173-225.

Potter, P.E., 1978, Structure and Isopach Map of the New Albany Chattanooga - Ohio (Devonian and Mississippian) in Kentucky: Central Sheet; Kentucky Geological Survey, Series XI, University of kentucky, 1 Sheet.

Peng, S.S., and Ortiz, C., 1972, Crack Propagation and Fracture of Rocks Loaded in Compression; Proc. Int'1. Conf. Dynamic Crack Propagation, Lehigh Univ., p. 13-129.

Reichard, J.S., 1984, Fracture studies, lineament analys is and geology of the Temple Hill, Freedom und Gamaliel 7.5 minute quadrangles, south-central Kentucky, unpublished Master's thesis, University of Toledo, Toledo, Ohio, p. 163

Roberts, A.F., 1977, Geotechnology. 1st ed., Oxford, NY, Pergamon Press.

Schwalb, H.R., and Potter P.E., 1978, Structure and isopach map of the New Albany-Chattanooga-Ohio shale (Devonian-Mississippian) in Kentucky: central sheet, Kentucky Geological Survey, series $x$, scale $1: 250,000$. 
Smith, M.B., Holman, G.B., Fast, C.R., and Covlin, R.J., 1978, The Azimuth of Deep, Penetrating Fractures in the Wattenberg Field; Jour. Pet. Tech., p. 185-193.

Tetra Tech, Inc., 1981, Evaluation of Devonian Shale Potential in Eastern Kentucky/Tennessee; DOE/METC-121; report prepared for DOE/METC Under Contract No. DE-AC21-79MC10389.

Thill, R.E., and Bur, T.R., 1969, An Automated Ultrasonic Pulse Measurement System; Geophysics. v, 34, no. 1, p. 101-105.

Thi11, R.E., and Peng, S.D., 1974, Statistical Comparison of the Pulse and Resonance Methods for Determining Elastic Moduli; U.S. Bureau of Mines RI 7831, $9 \mathrm{p}$.

Wilson, E.N. and Sutton, D.G., 1976, 0il and Gas Map of Kentucky, Sheet 4, Eastern Part; Kentucky Geological Survey, University of Kentucky, Series $X$. 

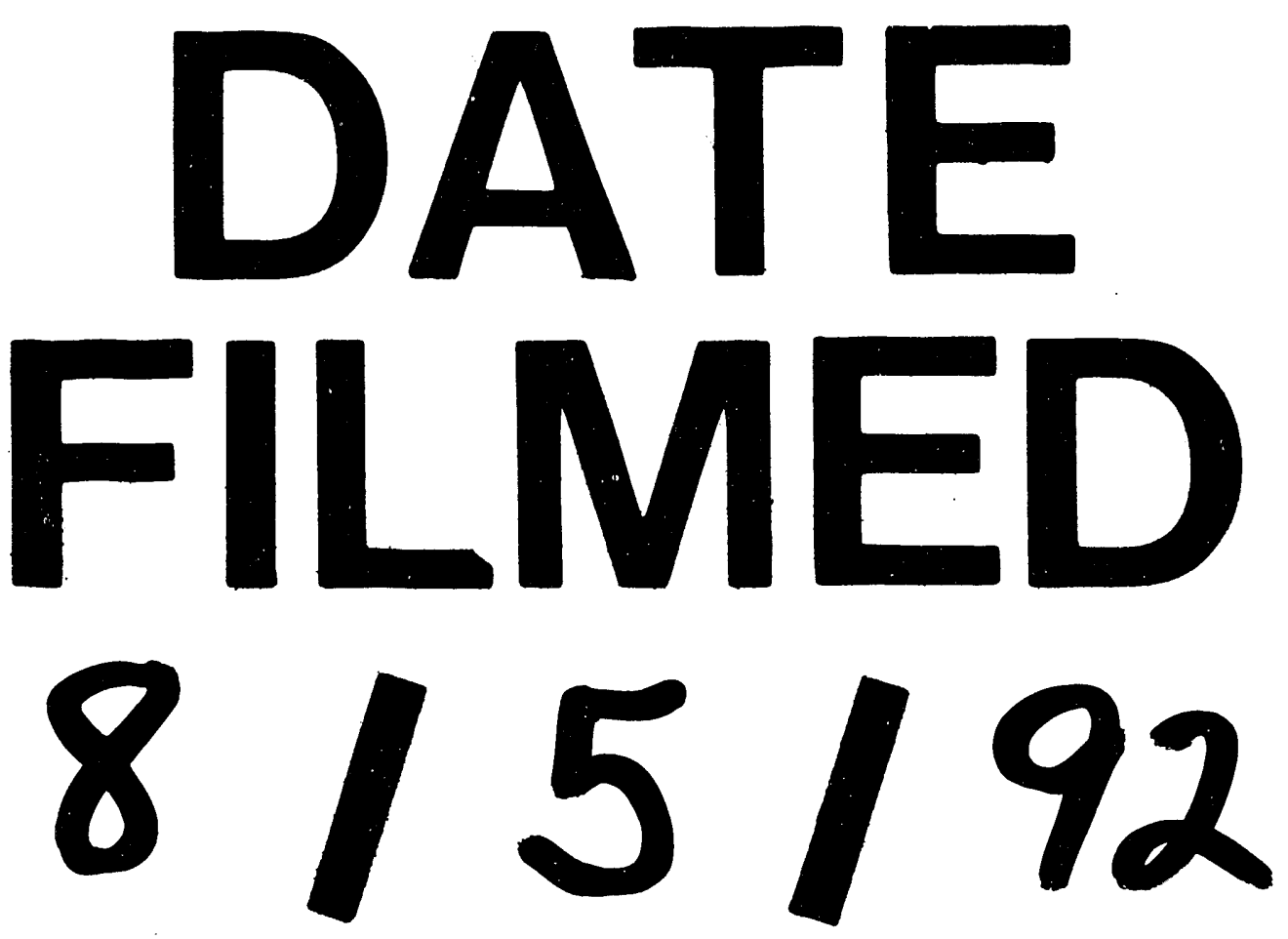


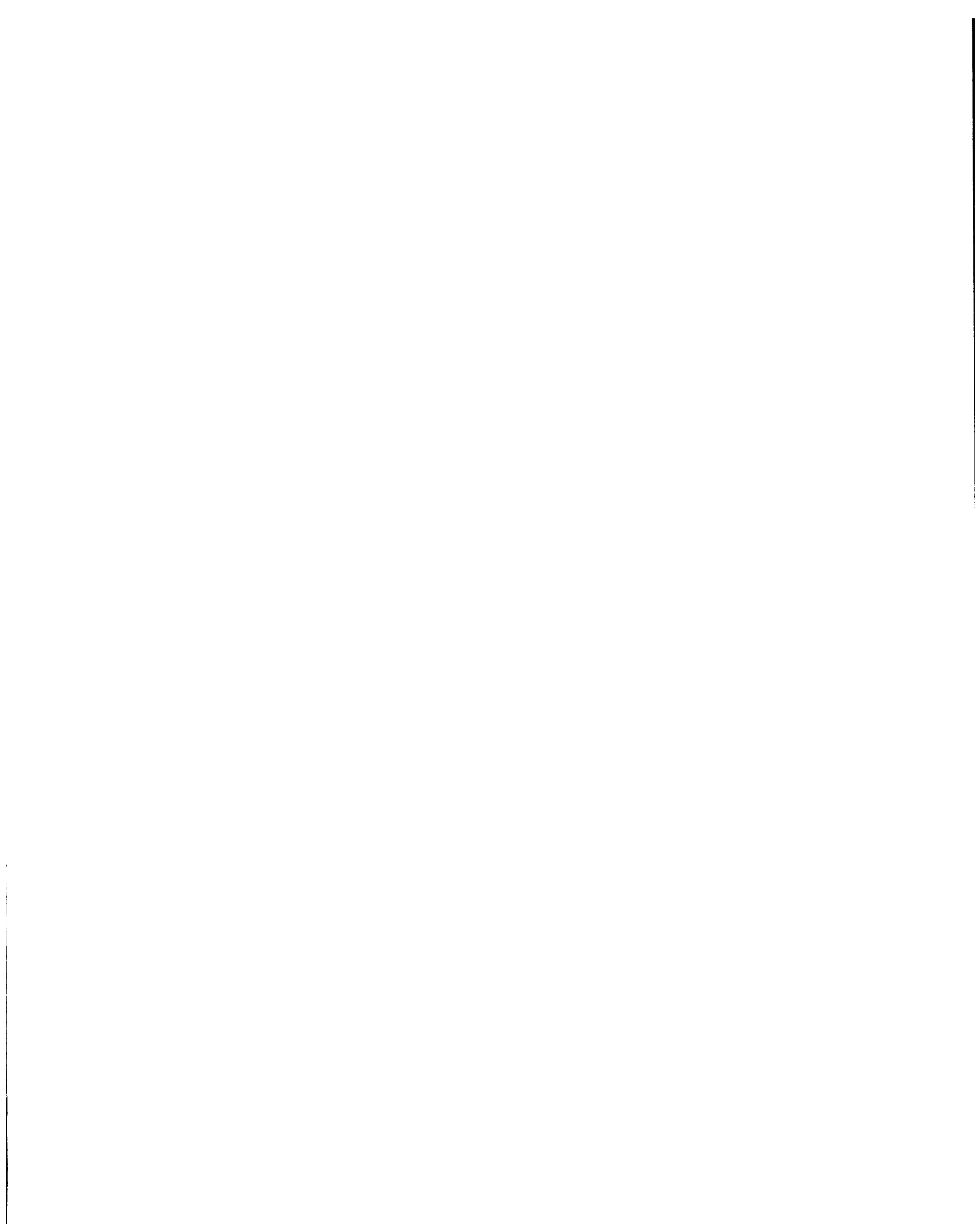

